University of Louisville

ThinkIR: The University of Louisville's Institutional Repository

Electronic Theses and Dissertations

$5-1936$

\title{
A record and evaluation of changes in the College of the University of Louisville, September 1930 to June 1935.
}

Lily Elsie Detchen 1910-2002

University of Louisville

Follow this and additional works at: https://ir.library.louisville.edu/etd

Part of the Higher Education Administration Commons

\section{Recommended Citation}

Detchen, Lily Elsie 1910-2002, "A record and evaluation of changes in the College of the University of Louisville, September 1930 to June 1935." (1936). Electronic Theses and Dissertations. Paper 1776.

https://doi.org/10.18297/etd/1776

This Master's Thesis is brought to you for free and open access by ThinkIR: The University of Louisville's Institutional Repository. It has been accepted for inclusion in Electronic Theses and Dissertations by an authorized administrator of ThinkIR: The University of Louisville's Institutional Repository. This title appears here courtesy of the author, who has retained all other copyrights. For more information, please contact thinkir@louisville.edu. 
A RECORD AND EVALUATION OF CHANGES IN THE COLLEGE OF THE UNIVERSITY OF LOUISVILLE SEPTEMBER 1930 TO JUNE 1935

\author{
A THESIS SUBMITTED TO \\ THE GRADUATE FACULTY OF \\ THE UNIVERSITY OF LOUISVILLE \\ IN CANDIDACY FOR THE DEGREE OF \\ MASTER OF ARTS \\ DEPARTMENT OF EDUCATION
}

L1ly Detchen

May 1936 
LIST OF TABLES...........................

LIST OF DIAGRAMS......................

\section{PART I . RESUME'}

Chapter

I. FOREWORD............................ I

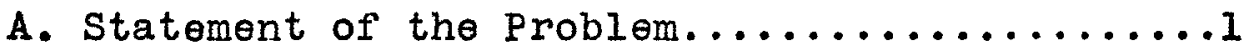

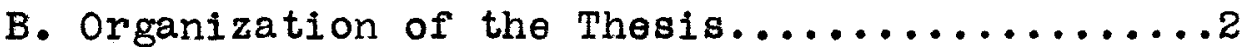

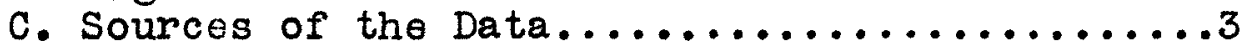

II . THE STORY OF FIVE YEARS' WORK..............4

A. The First Year, 1930-1931...............4

B. The Second Year, 1931-1932............... . .

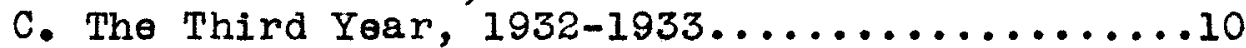

D. The Fourth Year, 1933-1934..............12

E. The Fifth Year, 1934-1935..............13

PART II. APPLICATIONS AND RESULTS

Chapter

I. THE AREA OF AIMS AND OBJECTIVES.............16

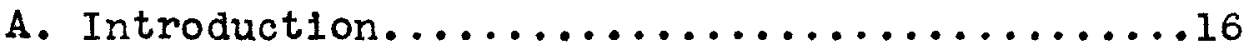

B. From the Viewpoint of offerings...........16

C. From the Viewpoint of Total Enrollment

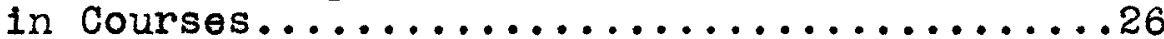

D. From the Vlewpoint of Electives.............35

E. From the Viewpoint of the Teaching Load.....39

F. From the Viewpoint of Student Retention and Mortality........................44

G. Chapter Summary -- The Status of the Curriculum in 1934-1935.............46

II. THE AREA OF INDIVIDUALIZING THE STUDENT . . . . . . 48

A. Introduction.....................48

B. The Instruments of Individualization......448

C. Chapter Summary....................62

II . THE SENIOR COLLEGE...................63

A. Introduction.....................63

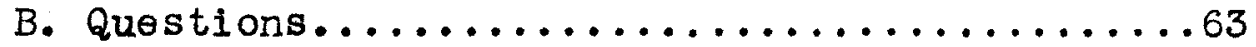

a. What have been the objectives of the Senior College?...............63

b. What changes have occurred in the curriculum?..................63 
c. What were the changes in department and division enrollments?...........65

d. What were the changes in standards of judging grades?...............66

$\theta$. What has been the effect of applying discriminatory procedures in selecting Senior College students?...........70

$f$. What questions arise out of the results

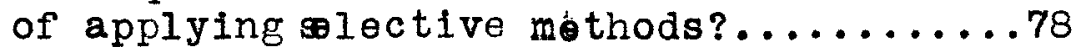

g. Has content become more difficult?.....80

h. What issues arise?..............82

i. What is the effect on the major?.......83

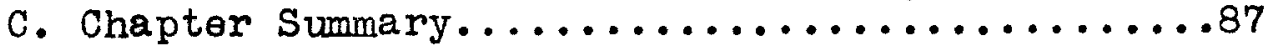

IV. THE EVALUATION OF ACHI EVEMENT $\ldots \ldots \ldots \ldots \ldots \ldots$

A. Introduction.....................89

B. Measuring the Achievement of Individuals....89

C. Measuring the Program as a Whole..........93

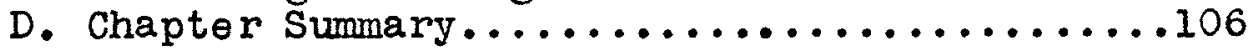

V. SENIORS' RATING OF THE COLLEGE.............

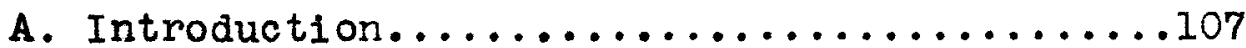

B. Survey Returns......................107

C. Chapter Summary....................11

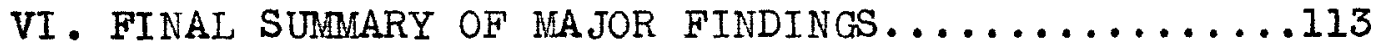

VII. SUGGESTIONS FOR FUTURE PROGRAM AND RESEARCH....116

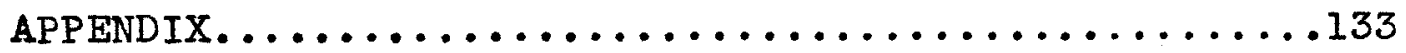

A. Objectives Adopted for the Junior College by the Faculty of the College...................

B. Objectives Adopted for the Senior College by the Faculty of the College..............135

C. List of Evidences of Institution's Study of Its Problems during the Period..........137

D. Students' Reasons for Taking Independent Study..............................

E. Tities of Courses in Independent Study......148

F. Organization of Faculty Committees to Formulate a General Program for the College........149

G. Proposals Concerning the General Organiza-

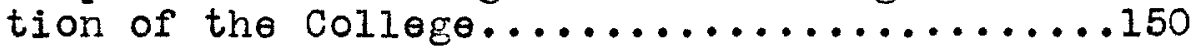


TABLE

PAGE

I. SUMMARY OF REASONS FOR WITHDRAWALS OF OLD COURSES DURING THE PERIOD 1930-1931 AND

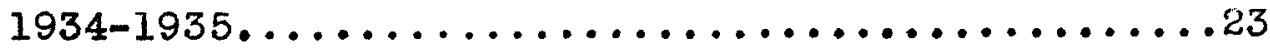

II. AMOUNT OF STUDENT REGISTRATION IN THE OLD

AND NEW TYPE COURSES COMPARED BY DEPARTMENTS

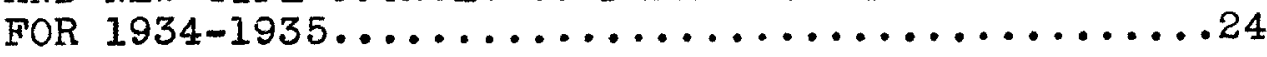

III. SUMMARY OF OBJECTIVES FOR COURSES ADDED

BETWEEN 1930-1931 AND 1934-1935.............27

IV. SUMMARY OF OBJECTIVES EMBODIED IN OLD

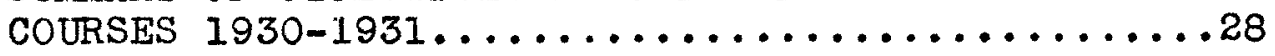

V. SUMMARY OF OBJECTIVES EMBODIED IN

PRESENT OFFERINGS $1934-1935 \ldots \ldots \ldots . . \ldots . . . \ldots 29$

VI. CHANGES IN COURSE REGISTRATIONS EXPRESSED

IN THE ACTUAL NUMBER OF COURSE REGISTRATIONS

AND ALSO IN THE PER CENT GAIN OR LOSS IN THE

NUMBER OF COURSE REGISTRATIONS, FOR THE

FIRST SEMESTER OF 1930-1931 AND 1934-1935......31

VII. PERCENTAGE OF REQUIRED AND ELECTIVE COURSES

IN 1934-1935 DISTRIBUTED BY COLLEGES, DIVI-

SIONS, AND DEPARTMENTS FOR TWENTY PER CENT

SAMPLING OF STUDENTS FROM ALL ACADEMIC LEVELS . . . 36

VIII. COMPARATIVE ENROLLMENTS - UNIVERSITY OF

LOUISVILLE COLLEGE OF IIBERAL ARTS. . . . . . . . . . . 40

IX. SIZE OF CLASSES COMPARED 1930-1931 AND

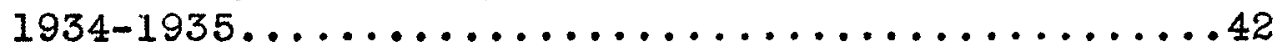

X. DISTRIBUTION OF CLASSES BY SIZE FOR THE

JUNIOR AND SENIOR COLLEGES FOR FIRST SENESTER

OF 1930-1931 AND 1934-1935...............43

XI. NUMBER OF STUDENTS ENROLLED AT EACH ACADEMIC

LEVEL COMPARED FOR 1930-1931 AND 1934-1935......45

XI.B. STUDENT MORTALITY AT EACH ACADEMIC LEVEL

COMPARED FOR 1930-1931 AND 1934-1935.........45-b

XI I . ENROLLMENTS IN INDEPENDENT STUDY.............53

XIII. DISTRIBUTION OF COURSES IN INDEPENDENT

STUDY BY DEPARTMENTS. .53 
TABLE

XIV. COMPARISON OF EXPERIMENTAL AND CONTROL GROUPS OF FRESHMEN UNDER PLAN OF SOUTHERN ASSOCIATION OF COLLEGES AND SECONDARY SCHOOLS............................ 55

XV. PER CENT OF LETTER GRADES RECEIVED BY SENIORS IN 1930-1931 AND 1934-1935

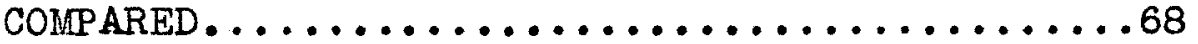

XVI. GENERAL POINT AVERAGES AND STANDINGS ON COLLEGE ACHIEVEMENT TEST COMPARED FOR SENIORS OF 1930-1931 AND 1934-1935........68

XVII. INTERCORRELATIONS OF SOME OF THE SECTIONS OF THE COOPERATIVE NATIONAL SOPHOMORE TESTS AND OF SOME OF THE NATIONAL TESTS WITH LOCAL SOPHOMORE TESTS...............72

XVIII. SCHOLASTIC STATUS OF THREE GROUPS OF JUNIORS DISTINGUISHED BY THE CRITERIA ADOPTED BY THE COMMITTEE ON SENIOR COLLEGE ADMISSIONS . . . . . . . . . . . . . . . . 77

XIX. RELATION BETWEEN ACHIEVEMENT IN THE NATIONAL SOPHOMORE TESTS AND THE AREA OF SELECTION OF THE MAJOR................

$X X$. THE NUMBER OF MAJORS BY DEPARTMENT AND YEARS - 1930-1935................... 85

XXI. THE ADJUSTMENT OF GRADES TO INTELLIGENCE LEVELS.

A COMPARISON OF GRADES BY SUBJECTS AND INTELLIGENCE TEST PERCENTILES FOR FRESHMEN OF THE FIRST SEMESTERS OF 1930-1931 AND

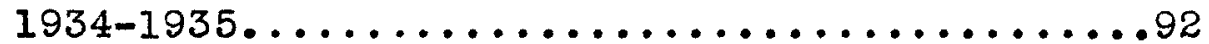

XXII. DISTRIBUTION OF GRADES FOR THE COLLEGE......93 
LIST OF DIAGRAMS

Figure

Page

1. COLLEGE ACHI EVEMENT TEST DISTRIBUTION OF

SCORES BY PERCENTILIS IN 1931 AND 1935.......71

2. THE QUALITY POINT STANDING OF SINGLE

MAJORS COMPARED FOR FIRST SERESTERS OF

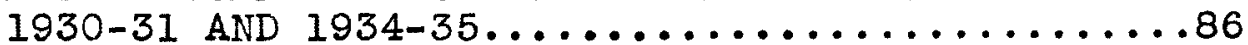

3. COLLEGE STANDING BY MEDIANS AND QUARTILES

FOR ENTERING FRESHMEN OF SEP TEMBER 1930, $1931,1932,1933,1934$, AND 1935 ON AMERI CAN

COUNCIL PSYCHOLOGICAL EXAMINATION...........96

4. THE FIRST, SECOND, AND THIRD QUARTILE

POINTS FOR UNIVERSITY OF LOUISVILIE

FRESHMEN ON THE COOP ERATIVE ENGLISH TEST

COMPARED WITH NATIONAL NORM..............97

5. THE FIRST, SECOND, AND THIRD QUARTILE

POINTS FOR UNIVERSITY OF LOUISVILIJE

FRESHMEN ON THE KENTUCKY CIASSIFICATION

TEST COMFARED WITH NORMS FOR STATE

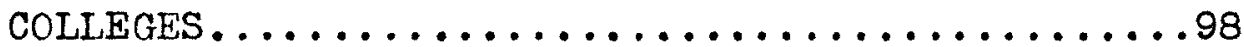

6. THE FIRST, SECOND, AND THIRD QUARTILE

POINTS FOR UNIVERSITY OF LOUI SVILLE

FRESHMEN ON THE NELSON-DENNY READING

TEST COMPARED WITH NATIONAL NORM............99

7. ACHIEVEMENT OF SOPHOMOE CLASS OVER A

FOUR-YEAR PERIOD - YEARLY PLACEMENT OF

MEDIANS ON NATIONAL SOPHOMORE TESTS,

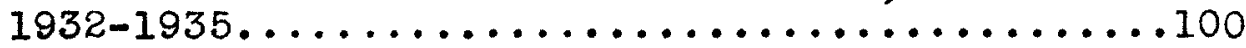

8. NATIONAL COLLEGE SOPHOMORE TEST PLACE-

MENT OF LOCAL MEANS OF SOFHOMOR E CLASSES

OF 1932, 1933, 1934, 1935...............101

9. ACHIEVEMENT OF GRADUATING S ENIORS. PIACEMENT OF OUR MEDIANS AND QUARTILES ON THE PENNSYIVANIA COLIEGE ACHIEVEMENT

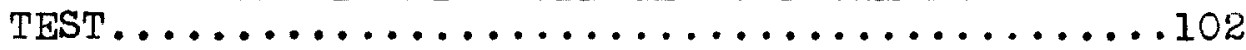

10. CHANGES IN PIACENENT OF MEDIANS BETWEEN

1931 AND 1934 ON COLLEGE ACHI EVEMENT

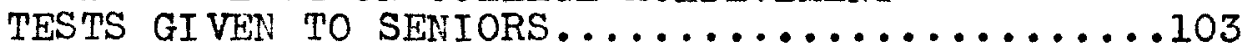


A RECORD AND EVALUATION OF CHANGES IN THE

COLLEGE OF THE UNIVERSITY OF LOUISVILLE 1930-1935

\author{
Chapter I. FOREWORD \\ Statement of the Problem
}

During the years since the inauguration of Dr. Raymond A. Kent as president and Dr. J..J. Oppenhelmer as dean, the faculty of the College of Liberal Arts of the University of Louisville has taken swift, decisive strides towards reorganization of the College. The curriculum of the College, and curriculum here connotes both the program of studies and all the activities that support 1t, has been the focal point of reorganizational activities. In his Annual Report to the President in 1933, Dean Oppenheimer made the following statement:

"The future will tell whether or not the quality of learning will be changed by the particlpation of a faculty and student body in a more flexible scheme of education." This is the "the future," and those who have been contributing directly to the reorganization of the College are beginning to seok more objective evidences of progress to substantlate the more or less subjective evaluations that they have already made as the various movements have gathered momentum. For interested individuals outside the College, there are but few tangible records of the progress of the Loulsville curriculum experiments. The purpose of this thesis is therefore, two-fold: 
(1) to present a record of changes and experiments in the College during the five year period beginning in 1930-31, and ending in 1934-35;

(2) to evaluate these changes to whatever extent permitted by the available data.

\section{Organization of the Thesis}

Those who have followed the trends of reorganization in the College will agree that they have centered in cortain main areas, namely: the adaptation of alms and subject matter to the noeds of atudents, the individualization of the student, the delineation of a line of distinction between the Junior and Senior Colleges, the promotion of a more wholesome campus life, and finally the introduction of an adequate ovaluation of achievement. Regardiess of the experimental activities of other colleges, regardless of the intrinsic value of any one of these areas or of all collectively, all oridence emphasizes them as focal issues in this particular situation. The logic of the thesis will, therefore, take the following form:

Part One, the story of five years' work, sketches in broad outlines the important innovations from year to year. An important addendum, a list of evidences of the institution's study of its problems, is presented in the Appendix.' Part Two, applications and results, is a description 
and evaluation of changes that evolved from the aforementioned new policies. These will be grouped within four of the areas described above. No attempt $\nabla 111$ be made to evaluate the fifth, the promotion of a campus iffe, due to the intangibility of the data. Evaluation takes the form of the presentation of the results obtained with standard tests, researches that have been made by way of appraisal and their import, and the opinions of senior students. The final chapter is a sumary of the main findings of the thesis.

Part Three, suggestions for a future program and research, results from the issues that arise in the thesis or that are conspicuously absent in reorganization.

Sources of the Data

Practically all of the data are original, obtained directly from the college records. The writer, in the capacity of research secretary in the College, had access to important repositories of materials. 
Chapter II. THE STORY OF FIVE YEARS' WORK

Introduction. This first chapter is concelved as a description of what actually transpired in the College during the reorganizational period. Later chapters will evaluate results, but first of all, for the benefit of the interested educationists who may look hopefully to the Loulsvilie reorganfzation for suggestions in some reorganization of their own, there must be a presentation of the initiatory steps. This chapter alms to answer such questions by presenting the measures that were taken in each year to further the alms of the new College. Problems that arose in research during these transitional years should also be suggestive to those initiating programs of their own, and for this reason a list of such problems is included in the Appendix. ${ }^{1}$

\section{A. The First Year, 1930-31}

The year 1930-31 was marked by initial preparation of the faculty to embark upon its reorganizational plans. Reorganization in the first year, if it may be so designated, is the story of a faculty's mobilization.

Faculty groups convened formally and informally to consider the problems of the College. Beginning early in the year, the College staff met weekly at faculty luncheons. To several of these meetings came invited guest speakers, experts in the field of higher education, to lay before the faculty 
their experiences in other colleges. Occasionally there Tere papers read by members of the faculty on some aspect of college methods.

There were more frequent faculty meetings than had previously been necessary. Moreover, these faculty meetings were professional in character. Where before they had been necessarily restricted to the consideration of administrative routines, they now became open to other discussions, through the assignment of detalls to an Executive Committeo for their consideration outside of the formal faculty meeting period.

Besides the luncheons and formal faculty meetings there were also held informal faculty discussion groups revolving about a topic presented by one member. An indication of the character of these meetings is obtained from the title of one of the papers read by an instructor in English, "Experiments in the Liberal Arts College." The meetings were under the auspices of a "Committee on Instruction" which had formed early in the year.

Culminating the activities of the faculty for the first year, there was in April 1931 an establishment of a comprehensive committeo set-up which embraced all aspects of the College revieion in curricula and policies and through which all College issues were administered in the following years. This set-up involved one supervisory comittee, designated the Steering Compltie日, and five subsidiary committees entitled the Committees on the Junior College Curriculum, 
Senior College Curriculum, Measurement of Achlevement, Improvement of Instruction, and Personnel Administration. Unity among committees was obtained through the Steering Committee whose members served as chairmen of the other committeos and whose chairman was the dean. A diagrammatic presentation of the set-up and the functions of each committer is included in the Appendix. I During the reorganizational period there were many outgrowths of these committees studying very specialized problems, but the initial groundwork remalned practically the same and is, in fact, still standing.

Attuned to the idea of faculty mobilization was the establishment of a research office, the purpose of which was to further and assist in all educational research that might be inaugurated. This office in its modest beginning was under the direction of a Research Committee of which the dean was chairman. A part-time research secretary with training in oducational method was omployed.

Besides faculty mobilization and the beginnings of reorganization, the first year was attended by other changes. Not all of these were directly related to reorganization, however. Some certainly would have occurred in spite of reorganization. Such further changes may be found in the annual reports of the dean of the College.

$1_{\text {Appendix, }}$ p. 149. 


\section{B. The Second Year, 1931-32}

In the second year there continued a faithful adherence to the idea of faculty professionalization. The faculty luncheons, addresses by educationists, and faculty papers were continued. In addition, a course taught by the dean of the College entitled "Problems of College Teaching," open to seniors in education, invited the attendance of faculty and required the attendance of all sentor and graduate assistants.

During this year the various major committees, established at the close of the first year, really set to work. From their progress reports submitted at the end of the second year may be read the story of their activities. The discussion of the Steering Comittee stressed the necessity of formulating general principles towards which to work rather than detalled programs, and the value of considering the position of the student rather than the importance of the subject and department. The Comittee on Personnel Administration re-formulated the freshman survey course, advised the issuance of a student handbook, considered the place of vocational guidance in the College, and examined and reported upon student record cards. The Committee on the Measurement of Achievement studied the use and contents of comprehensive examinations for various levels and the interpretation of results obtained from such. During the year the faculty 
approved the use of such examinations to terminate the Junior and Senior College periods. A sub-committee on honors was instrumental in creating the first Honors Convocation, which has become the culminating academic program of the College year. Its purpose was to award recognition to outstanding students and student groups.

Through the efforts of the Committee on the Improvement of Instruction three outside speakers were brought to the College. This Committee also established, and later accepted a report from, a student committee appointed by them to suggest changes for the College. The Committee aloo approved a student rating of faculty, proposed and executed in the third year by this student committee. Both the Junior College and Senior College Committees submitted prefiminary drafts of their proposals for the newly created upper and lower colleges.

But the continued activities of the reorganization groups of the first year do not tell the whole story for the second year. For in this year the faculty initlated plans independent of its previous activities, although always related to their primary objectives. In this second year the student was the theme, and oo many steps were taken to promote the student welfare for both individuals and student groups that a second thesis would be required to describe them in full. Dr. Hilda Threlkeld became dean of women. The fact that she was also chairman of the Committee on Personnel 
Administration provided a more unified correlation of all student welfare pollcies. Student measures inaugurated during the year were: the scheduling of student events to avoid conflicts, a Freshman Weok program, the revival of the Women's Student Govermment Association and the Student Council, a vocational guidance series sponsored by the Women's Student Government Association, the issuance of grades to students by their advisers at six-reeks' intervals, the tutoring of retarded students by seniors, alliance with the psychiatrist at the School of Medicine, required physical examinations for all students, a Committee on Student Relations to consider cases for discipline, interviews with graduating sentors, the opening of the gymnasiun for social gatherings, the organization of the Foman's Athletic Association, the Pallas Club and Inter-Fraternity Council -- both of the latter designed to unite fraternal organization in concerted colperation -- and the first annual University women's dinner.

The study of the foreign language requirement, followed by the recommendation of the use of the cobperative language tests in determining language qualification, was important in that it preceded many other such stands taken by the faculty in regard to the determination of achlevement. The measure replaced the acceptance of credit in fulfillment of the foreign language requirement and was the forerunner of the Sentor College admissions policy of evaluating progress 
by achievement rather than by credit accumulations.

The appearance of the survey courses and the beginnings of their accompanying syllabi presaged other survey courses in both the Junior and Senior Colleges. The first three survey courses, in the following years extended to a dozen or more, were entitled "Introduction to the study of Society," "The History of Civilization," and "General Humanities." The syllabi were furnished to give the student opportunity to proceed at his own rate, which was also typical of later faculty sentiment.

\section{The Third Year, 1932-33}

In the third year the theme might have been entitled, "achievement based upon performance," as practically all the major measures of this year pertained to evaluating achievement and interpreting the measurements in terms of student adjustments.

The department of English began to exempt from first semester English composition those students who demonstrated high achievement on the initial placement tests and psychological examination.

The accumulative personnel folder was adopted as the College student record card, and many data pertaining to the students' aptitude and achlevement began to be entered thereupon. This was consistent with the intention of a type of 
guidance analagous to the background of the individual. The Honors Compltte日, which had been actively at work for two years, submitted its recommendations for a special course to be made up of an honors group of freshmen and of a second course for the Sentor College of the same type. These courses were designed to give a challenging type of instruction and opportunity for discussion among themselves to the very superior. The Committee on Honors also drew up rules for graduation "with honors." To graduate with honors now became more than the achievement of a high quality point standing. Only those students who enrolled in the Senior College honors course were to be considered for the distinction. The final award was to be based upon point standing, a written document submitted by the student, and the opinion of the honors committee after oral examination. In May 1933 the first student was graduated "with honors in history."

In a year emphasizing the measurement of achievement, the Committeo on Examinations was naturally the most active. It approved plans for awarding credit by extra-mural examination and for administering independent study. This year first witnessed the use of standard tests in all Junior College subjects for which tests were available.

The faculty favored the policy of granting entrance credits for admission on the bases of (a) cumulative records of secondary schools, (b) satisfactory completion of standard secondary examinations which may be in general fields of 
knowledge and (c) personnel data. The Committeo on Examinations was also emporered to approve the administration of general comprehensive examinations to students who desired advanced standing. Under the plan it became permissible to allot credit in general fields of knowledge instead of specific subjects.

And finally in this year was created the Social Intelligence Division. While its curriculum was in general that of the Junior College there were especially recommended courses included. The Social Intelligence curriculum was intended for students who were unable or unprepared to carry Sentor College work. None of the Soclal Intelligence work counted towards a degree.

\section{The Fourth Year, 1933-34}

The principal new note in the year 1933-34 was the cobrdinating major course, intended as an integrating force in the Sentor College curriculum. For the first time seniors were required to pass examinations in the field of the major. In May 1934 sophomore students were required to fulfill admission requirements to the Sentor College partly by examination. The two main ideas behind this requirement were: (1) to differentiate between junior and sentor college work and (2) to make scholastic adjustments suited to the individual. In 1934 the sophomore student was required to pass local and national comprehensives in the five fields, emphasized in the 
Junior College curriculum of that time. The normative basis for qualification was the results of testing of 13,000 sophomores.

The divisional arrangement of courser was adopted, spreading over three divisions -- humanities, social sciences, and natural sclences, each directed by a faculty division head. This was another step to further the cause of integration of the fields of knowledge.

While the Social Intelligence division was not really abandoned, as far as purpose was concerned, the title "General Curriculum" was applied Instead of "Social Intelligence," and no particular courses were designated as part of it.

In this year there began to be circulated among the faculty a small paper known as the Research Office Bulletin. The Bulletin had two aims: (1) to keep the local faculty abreast of the steps being taken focally in educational research and (2) to keep the local faculty in touch with helpful educational news from other colleges. The Bulletin began to appear at the suggestion of a Research Committer which began to convene in this year.

\section{E. The Fifth Year, 1934-35}

In the fifth year the faculty was ongaged almost entirely in perfecting the plans of the preceding years. All of the survey courses had by May 1935 published their syllabi. The graduating class of this year was the first 
to have been graduated after sharing in all of the reorganizational features -- the Junior-Sentor College division, survey courses, collrinating major courses, fulfillment of language requirements by examination and all of the more individual features of guidance and methods of teaching. The placement tests which began in 1930-31 with an English test and psychological examination had extended to nine -- English, psychological, reading, American history, world history, contemporary affairs, forelgn language, biology, and chemistry, with each test filling its special place in the educational guidance of the student. Other measures with similarly modest beginnings had expanded considerably. Objective tests were widely used by most instructors, and many items had been accumulated as a reserve for test building. The survey courses had been greatly improved by revisions prompted by experience and student interests. Student relationships with faculty and with each other had become freer. The library was increased by the use of a fund assessed students in the survey courses. Division heads were granted the assistance of graduate students.

And finaliy, in the fifth year, the College took a step which was entirely representative of its educational philosophy and a public declaration of 1 ts acceptance of the achievement-merit banner. This step was the acceptance from the local high schools of thirteen students who had not fulfilled completely the requirements of the high school 
but who did demonstrate ability and preparation to pursue a regular college program. 
PART II. APPLICATIONS AND RESULTS 
PART II. APPLICATION AND RESULTS

Chapter I. THE AREA OF AIMS AND OBJECTIVES

A. Introduction. The objectives of a reorganizational program form the basis for all that it hopes to accomplish educationally. The revision of the objectives was, therefore, the most significant step taken by the College faculty and must necessarily be the most important emphasis of this thesis. The aim of the chapter will be, first, to describe the revision in objectives and thus the characteristic trends appearing in the withdrawals and substitutions of offerings during the five-jear period under consideration. A second purpose will be to describe and evaluate certain other changes effected through the revisions in course offerings, effects such as those occurring in course enrollments, college requirements, kind of elective work, the faculty teaching load, and finally in the amount of mortality among the student body. Accordingly, the chapter subdivisions will be reviewed (B) from the viewpoint of offerings; (c) from the viewpoint of total enrollments in courses; (D) from the viewpoint of electives; (E) from the viewpoint of the teaching load; (F) from the viewpoint of student retention and mortality; and finally (G) as the status of curriculum changes in $1934 \ldots$ a summary.

\section{B. From the Viowpoint of offerings}

The objectives of the college have been stated several 
times by the faculty of the college. They have been included in the Appendix ${ }^{1}$ in their entirety and as originally adopted by the faculty in 1933. Since that time they have been re-stated several times in various revisions issued through the faculty, in the annual reports of the dean of the College, in the printed outlines of individual courses, In the College Catalog. In sumary they amount to this: The Junior College aims to fulfill several objectives, namely to round out the general education of the student begun in high school, or to prepare him for the professional school, or to prepare him for the Sentor College. From the Senior College point of view, the aim is to accept only a group of students prepared to do work at a scholarly level; to set up the curriculum for the Senior College to provide the maximum of integration and proficiency in the chosen field of study whether the student's interest is cultural or vocational. Distinguishing the aims of the Junior College and Senior College is the fact that each is a separate curriculum, differentiated as well by the type of instruction as by the type of offerings.

a. The Nature of the College. The statement in the Catalog of the College of Liberal Arts describes the nature of the College as follows: "The College is divided into two

1 Appendix, p. 133 
main parts, differentiated by instruction and curriculum, the Junior College and the Senior College.

"The Junior College, which includes the freshman and sophomore years, has for its primary objective the completion of the general education which has been the major concern of the high school.

"During this period the student should broaden his knowledge of the world in which he lives, acquire any basic skills which are needed to live adequately in the modern soclety, and learm his own ablities and interests. As a secondary objective, the student who desires to continue his education in college should obtain those special skills, facts, and methods of thinking which are required for advanced study. On the junior college level there must be a far less degree of teacher guidance than was necessary on the high school level.

"Then the student enters the Senior, or professional, College he then has reached the university level of education, characterized by initiative, Independence of action, maturity in thinking, definiteness of purpose, and freedom from constant teacher guidance." 1

b. Methods of Realization. These alms as described were not in themselves revolutionary. It was the means which were taken to further them that were more noteworthy. For behind these general objectives always resided these 1deas:

${ }^{1}$ University of Loulsville Bulletin, Announcements, 1935-36,pp.6,7. 
(1) the College determined advancement on a basis of achievement rather than on the time-credit basis; (2) emphasis was greater on learning than on teaching, which meant that the student was responsible for his education; (3) the viewpoint for the entire College was towards integration and colrdination.

c. The Ner Versus the old in objectives. The faculty observed the spirit of the objectives as they were originally planned, re-shaping the curriculum in their form, but other Ideas developed, so that it cannot be said that the original objectives were adhered to to the letter. It is true that a statement of worthwile may anticipate an excellent program. But how much of this anticipation became realization is the important issue. This question may be answered partiy through an analysis of objectives as they were embodied in the program of offerings after the fifth year. To obtain a judgment of the amount of progress during the pertod under consideration it was necessary that the earlier period also be evaluated. To meet the demands of such a comparison the following procedure was followed as described:

d. Procedure for Comparing objectives in the Two Periods. In the procedure for comparing objectives in the two periods, 1930-31 and 1934-35, first the names of courses offered in 1930-31 were obtained from the 1930-31 catalog. Likewise the courses offered in 1934-35 were obtained from the Catalog of 
that year. In each instance the courses as listed were considered as embodying the objectives of the College, and therefore were included in the analysis whether they were actually offered or not. As a matter of fact, there were but several courses listed in the earlier period which were not offered, and in the later period only a few of the type that departments list for alternate jears. Second, lists including all objectives served by the old courses, another of the objectives for the new courses, and another of reasons for withdrawal of the old courses were drawn up. These statements were based upon evident reasons manifested in changes, the statements of department heads, the correspondence in the period intervening between 1930 and 1935 between the dean and department heads, and the bound volumes of course outlines. The three sets of "reasons" as they were finally obtained appeared as follows:

(1) Objectives Embodied in old Courses

1. Fulfillment of the cultural and historically academic tradition

2. Vocational offering

3. An understanding and an interpretation of the modern world

4. Tool

5. Integration and cosrdination of knowledge

6. Fulfiliment of life needs

7. Special group project

8. Creativeness, art appreciation

9. Provision for the superior student

(2) Objectives Embodied in Courses Added since 1931

1. Changes in the subject matter

2. Amalgamation of several courses -- the Survey

3. Provision for superior students

4. Vocational offering

5. Tool

6. Iffe needs, community neods, understanding the self 
7. Integration, co8rdination of knowledge

8. New courses of the usual type not previously offered

9. Liberalizing, cultural

10. Creativeness, art appreciation

(3) Reasons for Withdrawals of Old Courses

1. Transferred to Division of Adult Education

2. Transferred to the Graduate School

3. Technical course for a spectal group; no longer in demand

4. Change in name only, not really a change of content or "new" course

5. Replaced entirely by a more vital course; same name but entirely reorganized

6. Of the traditional type; Iittle need; simply dropped to make room for other courses

7. Combined with another course in the department

8, Now fulfilled in another department

9. Now fulfilled by another institution or agency

In the third step a summary table was drawn up under each set of "reasons" comparing the two periods and also setting forth the totals for the college. In the fourth step a sumary table was drawn up for the present objectives as they appeared in the total offerings of 1934-35, irrespective of the amount from the "old" and "new" curricula.

- Trends in objectives. It is realized that a simple tabulation of obvious objectives can well be accused of many inaccuracies. It is not exact, nor can it well be so. For instance, it seemed impossible to indicate fully a threefold change where, for example, two one-semester courses in prose and poetry were combined into one one-semester course, and transferred from the Senior College to the Graduate School. 
Likewise, some new courses taken by majors in English who intended to teach might, in a sense, have been classified in the "vocational" area, but they were indicated simply as "additions of the traditional type." In spite of the method of ascertaining objectives, unmistakably there have been particular trends in the College objectives which stood out in these studies. While those conversant with the program are aware of trends, it has been very difficult for them to provide objective evidence of them. That is to say, while there has been conviction, there has been only elusive proof. The tallying of the alms represents the attempt to present these trends objectively.

(1) Quantitative Accounting of Changes. During the 1930-1935 period there have been 93 courses withdrewn from listing in the Catalog of the College. 1 Fourteen of these were in the Junior College field while seventy-nine were on the Senior College level. During the period the number of courses offered was reduced from 204 to 187 . This total of 187 does not include courses listed as independent study. of the new courses added, 20 per cent were added to the Junior College curriculum and 80 per cent to the Senior College curriculum.

The greatest number of changes has taken place in the departments of English, sociology, history and political science.

$I_{\text {Søe TABLE I., p. } 23 .}$ 
TABLE I

SUMMARY OF REASONS FOR WITHDRAWALS OF OLD COURSES DURING THE PERIOD 1930-1931 AND 1934-1935

\begin{tabular}{|c|c|c|c|c|c|c|c|c|c|c|c|c|}
\hline \multirow[t]{2}{*}{ Reason } & \multicolumn{11}{|c|}{$\begin{array}{c}\text { Social Natural Humant- } \\
\text { Sciences Sciences ties } \\
\text { DEPARTMENT'S }\end{array}$} & \multirow[t]{2}{*}{ Total } \\
\hline & & 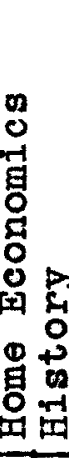 & & & 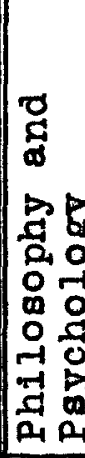 & & & & & 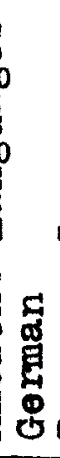 & 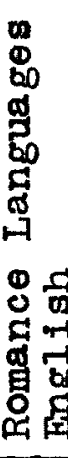 & \\
\hline $\begin{array}{l}\text { Division of Adult } \\
\text { Education }\end{array}$ & & & 1 & & & & & & & 1 & & 2 \\
\hline $\begin{array}{l}\text { Transferred to } \\
\text { the Graduate } \\
\text { School }\end{array}$ & & & & 1 & & & & & & & ] & 2 \\
\hline $\begin{array}{l}\text { Technical Course } \\
\text { for Special Group } \\
\text { No Longer in Demand }\end{array}$ & 1 & 1 & & & 1 & 1 & & 1 & & & & 5 \\
\hline $\begin{array}{l}\text { Change In Name Only } \\
\text { Not realiy a Change } \\
\text { of Content or "New" } \\
\text { Course }\end{array}$ & & & & 3 & & & & 1 & & 4 & 8 & 10 \\
\hline $\begin{array}{l}\text { Replaced Entirely by } \\
\text { a More Vital Course; } \\
\text { Same Name But En- } \\
\text { tirely Reorganized }\end{array}$ & & & & & & & 1 & & & & 8 & 3 \\
\hline $\begin{array}{l}\text { Of the Traditional } \\
\text { Type; Littie Need; } \\
\text { Simpiy Dropped to } \\
\text { Make Room for other } \\
\text { Courses }\end{array}$ & & $6 \pi$ & & 12 & & & & 4 & 1|| 2 & & 6 & 44 \\
\hline $\begin{array}{l}\text { Combined with Another } \\
\text { Course in the Depart- } \\
\text { ment }\end{array}$ & & $3 \mid 5$ & & & & & 2 & & & & 8 & 19 \\
\hline $\begin{array}{l}\text { Now Fulfilled in } \\
\text { Another Department }\end{array}$ & & & 2 & & & & & & & 1 & & 3 \\
\hline $\begin{array}{l}\text { An Fulfilled by } \\
\text { Another Institution } \\
\text { or Agency }\end{array}$ & & & & & & & & & & 2 & & 2 \\
\hline
\end{tabular}

Read: One course in the department of economics, division of the social sciences was withdram during the period 1930-1935 because it was "Transferred to the Division of Adult Education." 
With the greatest number of withdrawals and bulk of additions accredited to the Senior College, it would seem that reorganization of the curriculum in the Junior College has consisted mainly of the introduction of the survey courses with little adjustment elsewhere in that curriculum.

A simple tabulation of the number of students enrolied in the traditionally academic type of courses and of the number enrolled in the newer type of course shows two-thirds onrolled in the old-type, one-third in the new-type. The tabulation by departments is given in TABLE II.

\section{TABLE II}

AMOUNT OF STUDENT REGISTRATION IN THE OLD AND NEW TYPE COURSES COMPARED BY DEPARTMENTS FOR 1934-35

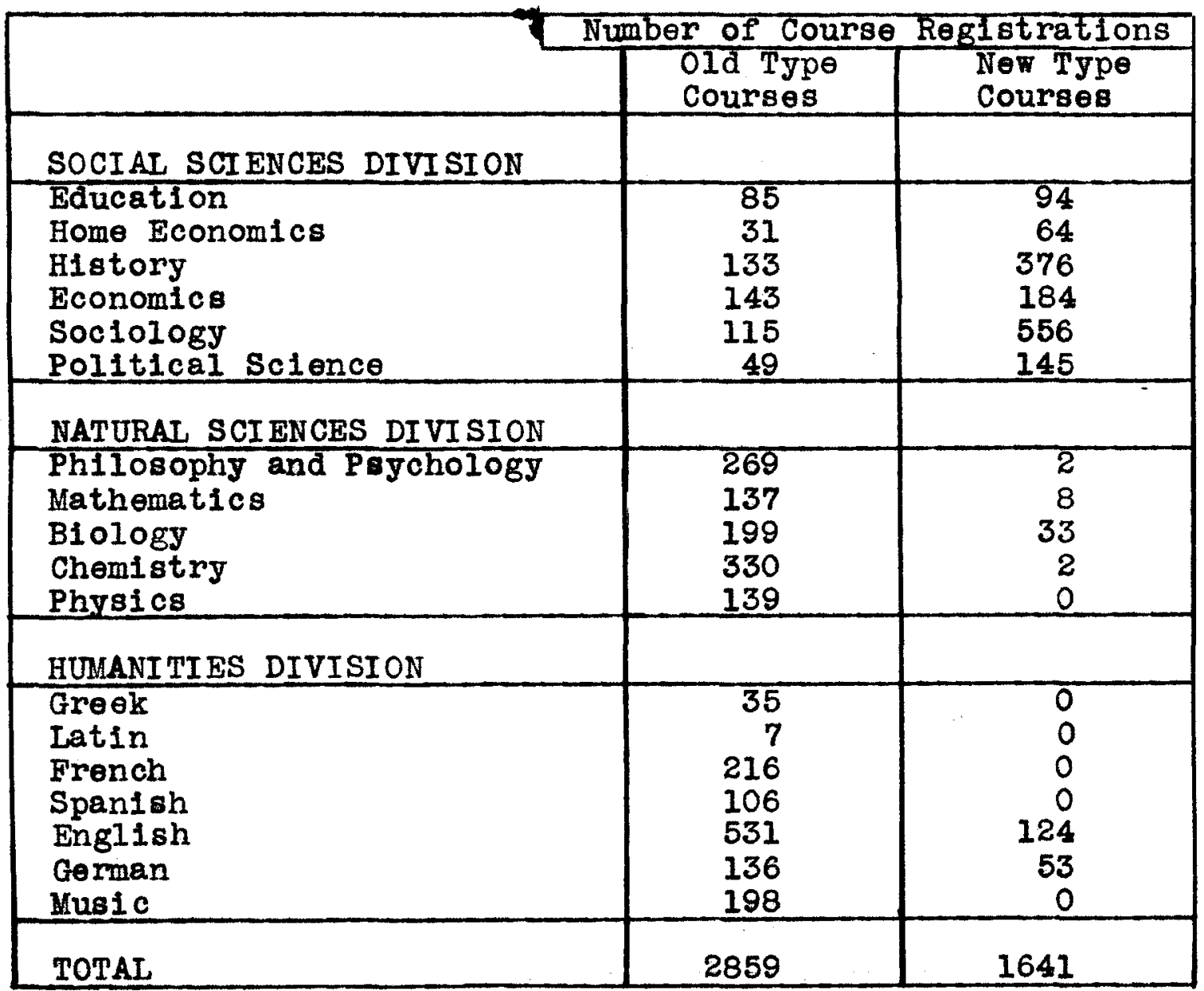


(2) Qualitative Accounting of Changes. A quantitative accounting of change is not sufficient to the understanding of changes. This question can be settled only by an investigation of the reasons for withdrawals of courses and of the objectives which the newly added courses were expected to fuif111.

Referring again to Table I, it may be read that approximately half of the courses were withdraw because they were "of the traditional type for which there was little need." They were dropped simply to make room for other courses. Herein lies the first indication of the quality of change: (1) A trend away from the traditionally academic. Table I shows the second welghtiest reason to be "combined with another course in the department." Herein lies the second definitive: (2) trend towards integration, or, possibly, generalization. The third and last "reason" of any significance in Table I is "change in name only, not really a new course." Whether a change of this nature should be described as a real change is questionable. Reasons remaining for withdrawals may be summarized Into a third trend, (3) towards elimination of duplication among the schools, departments, or organizations providing higher education to the students of the College.

(3) Generalization. If Table III is examined for the types of objectives embodied in courses added since 1930-31, the most outstanding trends are revealed as provisions for the superior student; re-emphasis towards integration and 
colrdination; provision for life needs; provision for vocational training; civic education; and the addition of certain courses of the traditional, cultural type not offered formerly. The data in Table V $\frac{1}{5}$ a summary of objectives embodled in the present offerings of the departments, separated for the Junior and Senior Colleges, are found to be in striking contrast to offerings of 1930-31 as shown in Table IV. 2 This contrast is an emphatic trend away from the traditionally academic. If the information here is combined with that already presented, this generalization may be drawn: There has been an 80 per cent turn-over in the Sentor College offerings and a 20 per cent turn-over in the Junior College offerings which have been brought about by the withdrawal of courses of the traditionally academic type and the substitution of courses whose objectives, best characterized as of cultural, contemporary, integrative, functional, and vocational emphasis, previously had appeared but rarely, if at all, in the college curriculum.

\section{From the Viempoint of Total Enrollment in Courses}

The preceding analysis of course objectives demonstrates some of the intentions of the faculty in roorganization. Other and further interpretations of reorganization may be obtained from a consideration of present and past enroliments in courses. To grasp the entire scene, both objectives and enrollments in courses with the accompanying policies influencing enroliments,

1

Table V, p. 29

$2_{\text {Table IV, p. } 28}$ 
SUMMARY OF OBJECTIVES FOR COURSES ADDED BETWEEN 1930-1931 AND 1934-1935

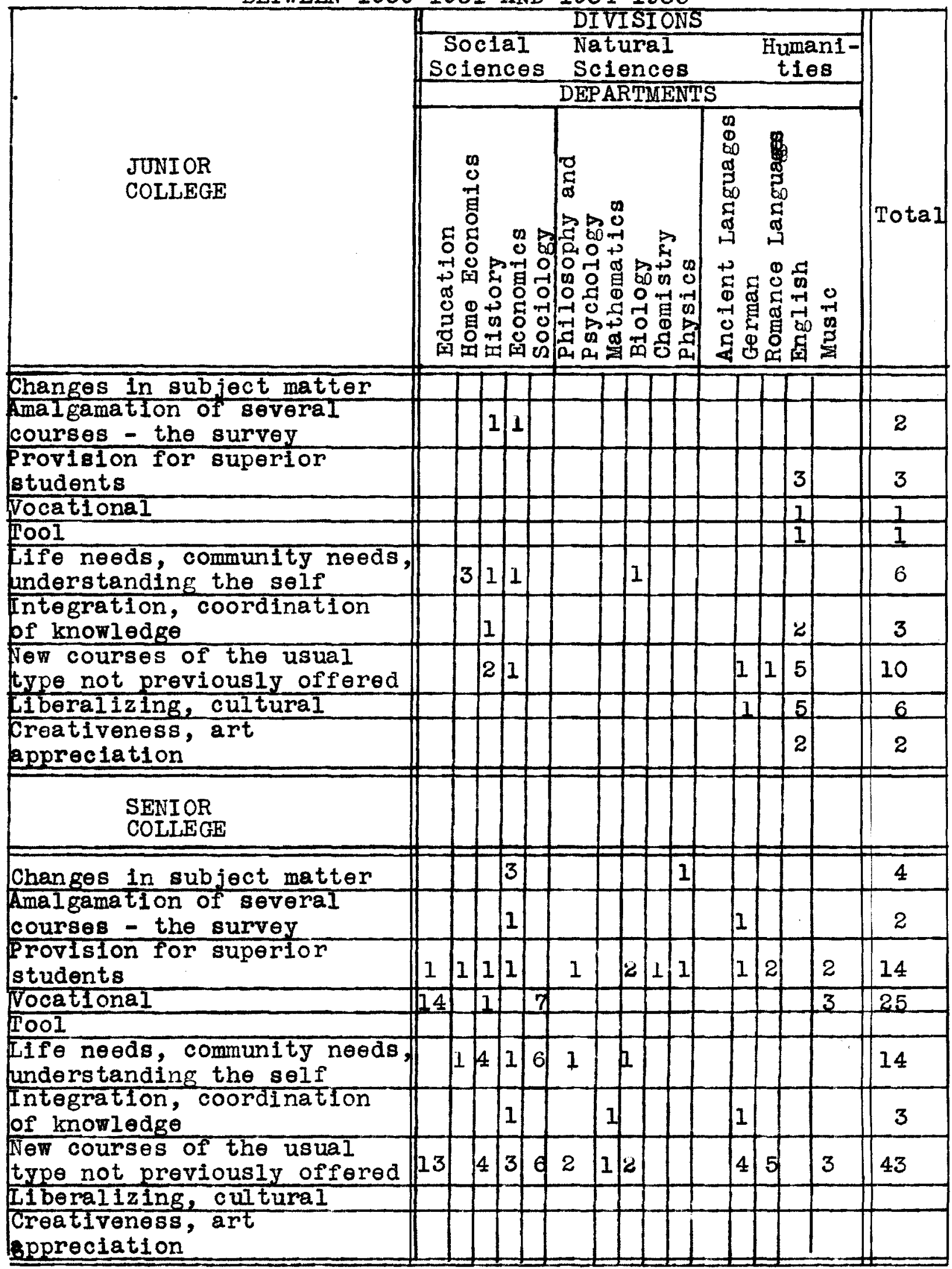

Read: Between 1930-31 and 1934-35 one course of the survey type was added in the department of history. 
TABLE IV.

SUMMARY OF OBJECTIVES EMBODIED IN OLD COURSES 1930-1931

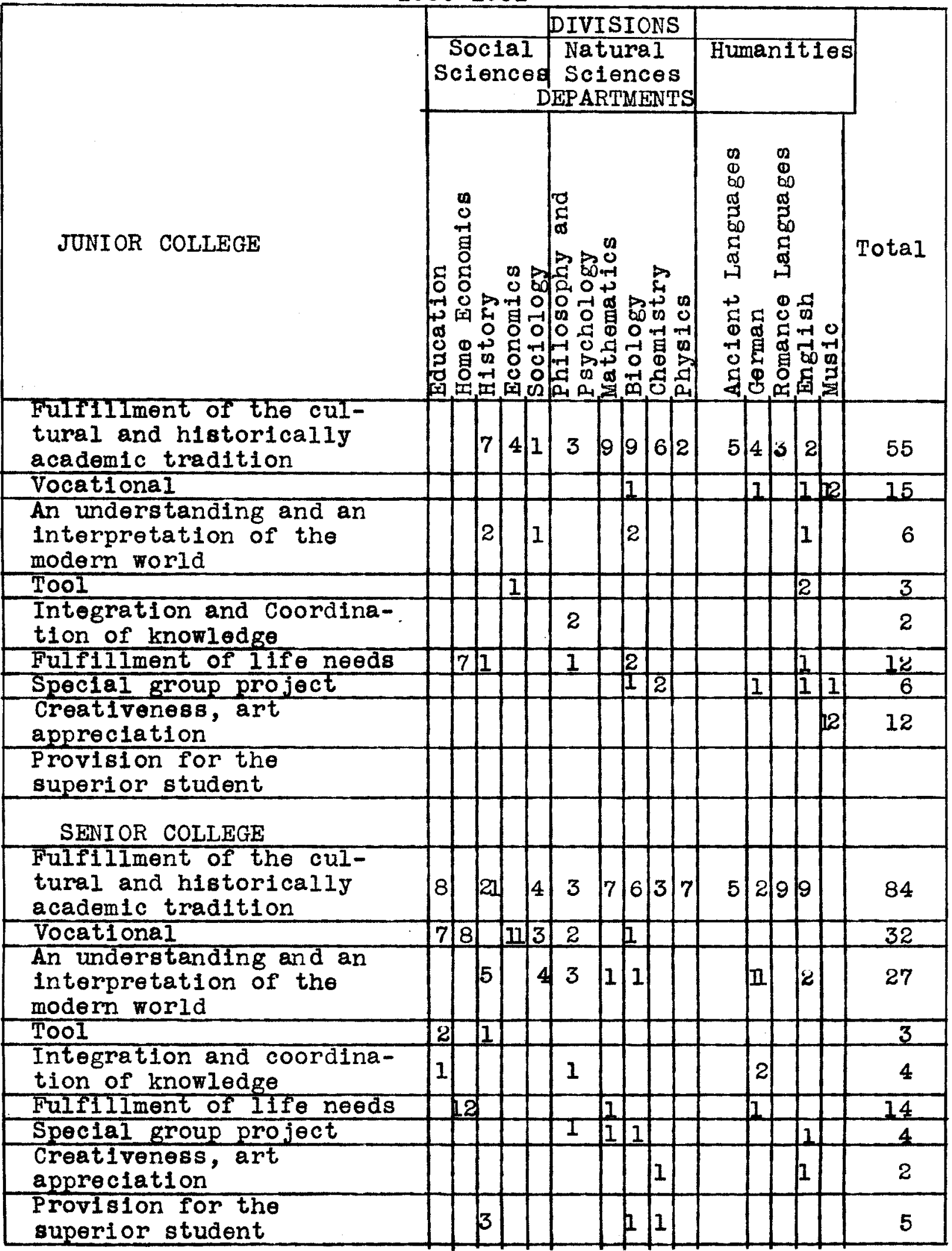

Read: In 1930-31 the department of history, division of the social sciences offered seven courses in the Junior College which emphasized the objective, "fulfillment of the cultural and historicallyacademic traditions," and twenty-one in the Senior College. 
TABLE $\mathrm{V}$.

SUMMARY OF OBJECTI VES EMBODIED

IN PRESENT OFFERINGS 1934-1935

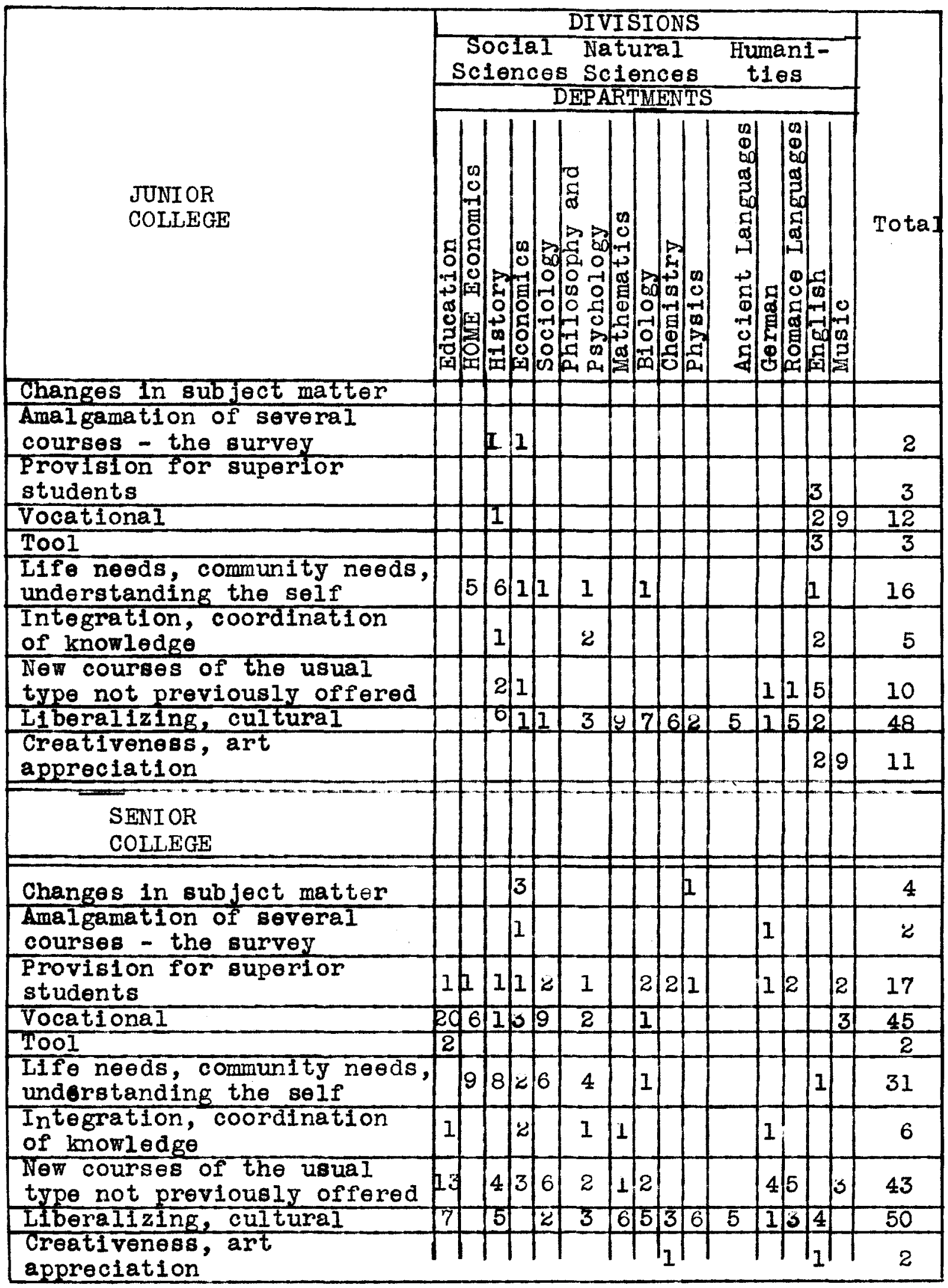

Read: In 1934-1935 the department of history offered one course of the survey type in the Junior College and none in the Senior College. 
must be considered. Course registration, it is especially pointed out, is not only an indication of trends in the College but of trends in the local society to which the College responds.

a. Procedure. The number of students appearing on the class rolls for the first semester of 1930-31 and 1934-35 was recorded by departments, distinctions being made within departments between the upper and lower colleges, and summarles made of the gains and $10 s s e s$ by Colleges, departments, and years. Table VI presents the data both in percentage and in round numbers. These data on enrollment bear marked relationship to some of the changes, instituted in the College during the period under consideration which have not been brought out in other data.

b. The Requirement in Science. In the earlier period, students mere required to have had in high school or college a unit (year's study) of physical and of biological sciences. Usually, a student could fulfill only one of these requirements at the time of his entrance to college, so that he was required to take 10 semester hours of a science in his freshman year. In the later period, for students not preparing for professions specifically requiring the mastery of a science the requirement was 6 hours of Natural Sciences survey. This course really was not a required one. The requirement was that the student pass the sophomore comprehensive examination 
TABLE VI.

CHANGES IN COURSE REGISTRATIONS EXPRESSED IN THE ACTUAL NUMBER OF COURSE REGISTRATIONS AND ALSO THE PER CENT OF GAIN OR LOSS IN THE NUMBER OF COURSE REGISTRATIONS FOR THE FIRST SEMESTERS OF 1930-31 AND 1934-35

\begin{tabular}{|c|c|c|c|c|c|c|c|c|c|c|}
\hline \multirow[t]{3}{*}{ DIVISIONS } & \multicolumn{4}{|c|}{$\begin{array}{c}\begin{array}{c}\text { Number } \\
\text { of }\end{array} \\
\text { Registrations } \\
\end{array}$} & \multicolumn{2}{|c|}{$\begin{array}{l}\text { Per Cent } \\
\text { Gain } \\
\text { or Loss } \\
\text { COLLEGE }\end{array}$} & \multicolumn{4}{|c|}{$\begin{array}{l}\text { Per Cent of Course } \\
\text { Among Total Junior } \\
\text { or Senior College } \\
\text { offerings }\end{array}$} \\
\hline & JUNIC & & & NIOR & JR. & SR. & JU1 & VIOR & TSEN & IIOR \\
\hline & 1930 & 1934 & 1930 & 1934 & 1934 & 1934 & 193 & 193 & 4193 & 0193 \\
\hline Total Social Sclences & 749 & 1099 & 279 & 545 & 47 & 95 & 22 & 27 & 42 & 35 \\
\hline Total Natural Sclences & 1360 & 834 & 219 & 379 & -37 & 73 & 40 & 26 & 28 & 32 \\
\hline Total Humanitios & 1068 & 1228 & 337 & 333 & 13 & $-I$ & 38 & 47 & 30 & 32 \\
\hline Total College & 3177 & 3161 & 835 & 1257 & 0 & 51 & 100 & 100 & 100 & 100 \\
\hline DEPARTMENTS & & & & & & & & & & \\
\hline Anclent Languages & 12 & 7 & 4 & 35 & -42 & 775 & 5 & $\overline{2}$ & 4 & 3 \\
\hline Biology & 392 & 96 & 61 & 116 & -75 & 90 & 9 & $\overline{2}$ & 7 & 8 \\
\hline Chomigtry & 564 & 247 & 30 & 76 & -56 & 153 & 14 & 6 & 11 & $\overline{9}$ \\
\hline Economics & 168 & 108 & 78 & 38 & -36 & -51 & 3 & $\overline{4}$ & $\overline{9}$ & 4 \\
\hline Education & 0 & 0 & 33 & 131 & 0 & 299 & 0 & $\overline{0}$ & $\frac{6}{6}$ & $\frac{2}{5}$ \\
\hline English & 489 & 459 & 255 & 102 & -6 & -60 & 6 & 11 & 13 & $\overline{7}$ \\
\hline Gorman & 152 & 149 & 6 & 21 & -2 & 25 & 5 & $\overline{6}$ & 4 & 4 \\
\hline History & 361 & 399 & 73 & 80 & 10 & 10 & $\overline{9}$ & 6 & $\overline{7}$ & $\overline{7}$ \\
\hline Home Economics & 55 & 64 & 38 & 31 & 16 & -18 & 6 & 6 & $\overline{9}$ & 8 \\
\hline Mathematics and Astronon & 54 & 83 & 12 & 47 & 54 & 292 & 9 & 8 & $\frac{\pi}{4}$ & 5 \\
\hline Mus1c & 164 & 148 & 0 & 50 & -9 & 100 & 17 & 15 & 2 & 10 \\
\hline Philosophy and Psycholog & 211 & 181 & 116 & 64 & -14 & -45 & 5 & 4 & $\overline{6}$ & 6 \\
\hline Physics & 139 & 127 & o & 12 & -8 & 100 & $\overline{3}$ & 4 & $\overline{0}$ & $\overline{2}$ \\
\hline Romance Languages & 251 & $\overline{274}$ & 72 & 38 & -9 & -47 & $\frac{6}{6}$ & $\overline{9}$ & $\overline{7}$ & $\frac{\pi}{4}$ \\
\hline Soc10logy & 165 & 97 & 57 & 160 & -41 & 180 & 3 & 6 & 11 & $\overline{7}$ \\
\hline Humantities (New) & o & 191 & 0 & 87 & 0 & 100 & 0 & 2 & 0 & 3 \\
\hline Soclal Sclences (New) & 0 & 331 & 0 & 34 & 0 & 100 & 0 & 4 & $\overline{0}$ & I \\
\hline Political Science (Nem) & o & 100 & 0 & 71 & 0 & 100 & 0 & $\overline{2}$ & 0 & $\overline{4}$ \\
\hline Natural sclence (New) & o & 100 & o & 64 & 0 & 100 & 0 & 2 & 0 & $\bar{I}$ \\
\hline
\end{tabular}

Read: In the first semester of 1930 , there were 749 registrations in the Social Sciences Division, compared with 1099 in 1934. This was a gain of 47 per cent. In 1930 the Social Sciences Division offered in the Junior College 22 per cent of the total number of courses. In 1934 it offered 27 per cent of the total number. 
in this area. The changed requirement resulted in a 37 per cent loss in $J_{u^{n i o r}} \operatorname{College}$ enrollments in natural sciences. The old science courses as taught assumed the course to be introductory to the major of the department. Therefore, it is the more surprising that with the introduction of the new natural sciences survey course more students were attracted into advanced study than ever were through the old science course. Enrollment in Senior College sclence Increased 73 per cent although the number of offerings showed no noticeable increase.

c. The Requirement in Language. Formerly the student had to offer the equivalent of three college years of one language, or else two years of one language and one jear of a second language. In 1934 the student fulfilled the language requirement by examination. Many of the better atudents were able to do this after having had the equivalent of two semesters of language. The average student qualified at the end of his fourth semester in language. The standard set was slightly higher than the standard for college sophomores in a number of other institutions. The data on enroliments show an 11 per cent loss for Junior College French, German, and Spanish, a 708 s of practically half the enrollment in Senior College romance languages. The gain in German of 25 per cent is misleading, as the original number of students is small. It would seem, then, that the main interest of students in language is simply sufficient mastery to fulfill a college 
requi rement.

d. Gain in Senior College Enrollment. Formerly there was a rather promiscuous registration of college students in Junior college courses. The 1934 requirement allowed a student to present but one-sixth of his Senlor College work from the Junior College level. That registration in Senior College courses doubled is in part explained in the fact of this requi rement.

- Shifta in Enroliments In Divisions. In 1934 the humanties division offered in the Junior College about twice as many courses as any other division and more courses than it offered in 1930-31. In spite of this, enroliment declined sharply. The natural sciences division lost 37 per cent of its enrollment in the Junlor College, due to the change in the science requirement, as already explained. It offered in 1934-35 about half as many courses as the humanties division, but the same amount as the social sciences division and about one-third of 1ts 1930-31 offerings. The soctal sciences gained in enrollment by 47 per cent, although the number of offerings was proportionately the same.

In 1934-35 all divisions offered practically the same number of courses in the Senior College. This was in itself quite a change, since in 1930-31 the social sciences division was offering twice as many courses as either of the other two divisions. There is, perhaps, no reason that can be given for this, especially since in 1930-31 this division 
attracted no more students than any other division, except that which attributes an improper distribution of courses in the earlier period. Although the number of offerings was practically the same in 1934-35, enrollment varied widely. Registration in the social sciences was the greatest, the gain over that of 1930-31 being 95 per cent. Th1s gain, coupled with that of 73 per cent in the natural sciences, was in striking contrast to the standstill in the division of humanities.

f. Losses in Individual Departments. The significant losses in Junior Colloge departmental enrollments occurred in anclent languages, biology, chemistry, economics, and soclology. All of these losses are explained in new requirements. The language and science requirements have been explained. A former requirement of economics or sociology for sophomores was fulfilled by a survey course in the social sciences.

The significant losses in the Senior College course were in Finglish, home economies, economics, philosophy, and paychology, and romance languages. These losses, it seems, were explained in part by the great increases in enroliments in other departments, especially in the departments of the social sciences. The vocational openings in the city for women in sociology and the over-supply of teachers of English are suggested as possible reasons for the loss of English students. The situation in romance languages might be 
attributed to the same reason. In economics a shift into the Division of Adult Education explained some 10ss. The loss in home economics was quite small as the number of students affected was small in both periods.

\section{From the Viewpoint of Electives}

The objectives embodied in the offerings and the implication of the actual takings have been presented. A further distinction in the analysis is an examination of the nature of the takings. What light does the elective work of students throw upon the situation?

a. Procedure. Accordingly, the required and elective work of a sampling of 20 per cent students of Junior College standing ( 10 per cent of the freshmen, and 10 per cent of the sophomores) and 20 per cent of the Senior College students (10 per cent of the juniors and 10 per cent of the seniors) was determined for both periods, 1930-31 and 1934-35. In the Senior College the major courses, to the extent of 24 hours, were omitted from consideration in both periods. A course required in the Junior College as prerequistte to a major was classified as "required." A course outside of the department of the major but required of the major was classified as "required." Junior College survey courses which could be fulfilled by comprehensive examinations were classified as "elective."

b. Findings. See Table VII, page 36 . 
TABLE VII.

PERCENTAGE OF REQUIRED AND ELECTIVE COURSES IN 1934-35 DISTRIBUTED BY COLLEGES, DIVISIONS, AND DEPARTMENTS FOR A TWENTY PER CENT SAMPLING OF STUDENTS FROM ALL ACADEMIC LEVELS

\begin{tabular}{|c|c|c|c|c|c|c|c|}
\hline & \multicolumn{4}{|c|}{$\begin{array}{c}\text { Junior College } \\
\text { Students }\end{array}$} & \multicolumn{3}{|c|}{$\begin{array}{c}\begin{array}{c}\text { Sentor College } \\
\text { Students }\end{array} \\
\text { College }\end{array}$} \\
\hline & \multicolumn{2}{|c|}{ Junior } & \multicolumn{2}{|c|}{ Sentor } & Junior & \multicolumn{2}{|c|}{ Sentor } \\
\hline & 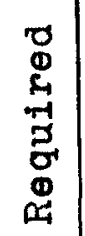 & $\begin{array}{l}0 \\
\stackrel{0}{+} \\
+ \\
0 \\
0 \\
0 \\
1\end{array}$ & 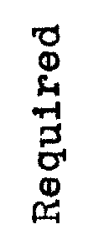 & 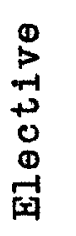 & 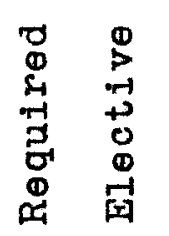 & 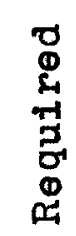 & 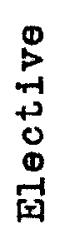 \\
\hline $\begin{array}{l}\text { Total } \\
\text { Social Sciences }\end{array}$ & & & & & 43 & 34 & \\
\hline Social Sciences & 24 & 13 & 44 & 48 & $33 \quad 19$ & 1 & 27 \\
\hline Economics & 5 & $I$ & I & & 2 & & \\
\hline Education & & & & 40 & & $3 \overline{3}$ & 13 \\
\hline History & 14 & 8 & 17 & 5 & 20 & & 7 \\
\hline Home Economics & 1 & 3 & 22 & $\overline{3}$ & 2 & & 7 \\
\hline Political Science & & & & & 17 & & \\
\hline Sociology & 4 & $I$ & & & 3 & & \\
\hline Humanitios Total & 42 & 37 & 33 & 15 & $69 \quad 32$ & 33 & 55 \\
\hline Ancient Languages & 0 & 1 & & & $\frac{10}{0}$ & & 7 \\
\hline fumanitios survoy & & & & & 5 & & 14 \\
\hline Engl1gh & 28 & 10 & & 15 & 24 & & \\
\hline German & & & & & 21 & & 20 \\
\hline French & 9 & & 22 & & 32 & $\overline{33}$ & 14 \\
\hline Spanish & 4 & $I$ & 11 & & 17 & & \\
\hline Music & 2 & 26 & & & & & \\
\hline FotaI & 29 & 50 & 17 & 35 & 25 & 33 & 13 \\
\hline Blology & $\frac{25}{12}$ & $\frac{5}{5}$ & & $\frac{50}{10}$ & $\frac{20}{4}$ & & $\frac{10}{7}$ \\
\hline Chomistry & 12 & $\overline{3}$ & & & 310 & & \\
\hline Mathomatics & $I$ & 10 & & $\overline{3}$ & $\overline{3}$ & 33 & \\
\hline Ph11080phy & & $I$ & & 5 & & & \\
\hline Psychology & 0 & 30 & 17 & 20 & 5 & & 7 \\
\hline Physiology & $\overline{3}$ & & & & & & \\
\hline Natural Solences & & & & & 4 & & \\
\hline
\end{tabular}

Note: Physical education and freshman survey have not been included in these computations.

Read: Based upon a 20 per cent sampling of students, $24 \%$ of the registrations in social sciences of Junior College students were in required courses and $13 \%$ in elective courses. Fourty-four per cent of Senior College work taken by Junfor College students was required, 48 per cent elective. 
c. The Amount of Elective Work. The data reveal that in 1934-35, students in the Junior College were permitted four times as much elective work as the students in the earlier period, their elective work constituting four-fifths of their total program. The foregoing statement is based upon the interpretation of the survey courses as elective. Students could avail themselves of the opportunity to qualify in history of clvilization or English composition, at the time of entrance to the College, on the basis that they might already have attained the necessary level of achievement in these two areas. Secondly, if pre-medical or pre-dental, or if simply interested in science courses, they could elect a science course rather than the survey course in natural science with reasonable certainty of obtaining sufficient preparation for the comprehensive. Third, the pre-taw or social sciences major could elect a series of courses, say, American history, American government, economics, or sociology with reasonable certainty of preparation for the comprehensive. Fourth, a student might elect English ilterature in preference to humanities survey if he wished. With these things in mind, the survey courses cannot be called "required." In another sense, however, they may be sald to have been required for the majority of students. The student had before him always the realization that comprehensives must be fulfilled at the end of the sophomore year. The best way of accomplishing this end was to take the survey courses, since the examinations 
were built around them. If the latter interpretation is made, and the survey courses put into the category of "required," It may then be demonstrated that in 1934-35 the Junior College had a 91 per cent "required" program compared to the 81 per cent "required" program of the previous period.

In summary, it is doubtful whether it can be said that the Junior College affords more electives now than in the former period.

On the other hand, the Sentor college definitely threw off in the later period the load of required work. In 1934-35 students were doing approximately one-half as much required work as in the earlier period. The bulk of requirement formerly was in foreign languages and in courses outside the department of the major but required for the major.

d. The Kind of Elective Work. Aside from the question of electives vs. requirements in the two periods there should be some consideration given to the departments attracting the bulk of free electives. In this connection it was found that in 1930-31 the bulk of Junior College electives was in music, peychology, mathematics, English, and history. In 1934-35 Junior College electives, other than the survey work, were scattered fairly evenly among all departments with some emphasis on chemistry and psychology. Unfortunately, the method of calculating by departments obscured real elective work for the departments which included the survey courses. 
It is very evident from students' records that the departments of English and history should also be classified as departments in which much of the Junior College elective work was accomplished.

In 1930-31, in the Senior College, elective work greatest in the departments of English, history, education, and psychology. In 1934-35 in the Senior College, biology showed a great gain, the other popular electives being education, history, ooclology and English.

\section{E. From the Viewpoint of the Teaching Load}

One of the purposes of reorganization was the reduction of the faculty teaching load. The emphasis upon greater individual derelopment of students seemed to make this mandatory.

a. Procedure. To determine whether reorganization brought about this desirable situation several factors of the two periods had to be weighed both singly and in relation to each other. These factors were: (1) comparative student enroliments; (2) comparative student lpads; (3) size of the faculty; (4) number of offerings; (5) size of classes; (6) number of classes.

b. Findings. (1) Comparative Student Enrollments. Enrollment was practically the same in both periods. In the day school classes there were enrolled 990 students in 1930-31 and 950 students in 1934-35. The distribution of 
enrollments by years is given in Table VIII.

TABLE VIII.

COMPARATIVE ENROLIMENTS - UNIVERSITY OF LOUISVILLE COLLEGE OF LIBERAL ARTS

\begin{tabular}{|c|c|}
\hline Year & No. of Students \\
\hline $1929-30$ & 1035 \\
\hline $1930-31$ & 990 \\
\hline $1931-32$ & 1006 \\
\hline $1932-33$ & 974 \\
\hline $1933-34$ & 909 \\
\hline $1934-35$ & 950 \\
\hline
\end{tabular}

(2) Comparative Student Loads. Referring back to Table VI, ${ }^{1}$ it 1111 be found that there were approximately 400 more registrations in courses, although the expected difference here besed on the difference in enroliment at an average of 5 courses per student would be about 125 . The difference seemed to lie almost wholly within the Senior College area. Evidently students in the Senior College were carrying a heavier schedule.

$1_{\text {Table }} \mathrm{VI}$, CHANGES IN COURSE REGISTRATIONS EXPRESSED IN THE ACTUAL NUMBER OF COURSE REGISTRATIONS AND ALSO THE PER CENT OF GAIN OR LOSS IN THE NUMBER OF COURSE REGISTRATIONS FOR THE FIRST SEMESTERS OF 1930-31 AND 1934-35, p. 31 . 
(3) S1z0 of Faculty. There was a slight reduction in the size of the faculty. In 1930-31 there were 44.5 instructors while in 1934-35 there were 42 instructors. A part-time professor was counted as .5 professor in each period.

(4) Number of offerings. It has already been pointed out that the number of offerings was reduced from 204 to 187.

(5) Size of classes. The number of smail classes, that 1s, classes enrolling 45 or fewer studente increased from 65 to 100. The number of classes averaging 16 to 30 students remained the same in both periods, 60 and 61 respectively. Sixty per cent of classes in 1834-35 had enrollments under 20 compared to 47 per cent formerly. The number of large classes increased in 1934, classes averaging 31 to 266 students numbering 56 per cent compared to 38 per cent in the earlier period. In the Senfor College there are now 66 small classes (under 10) compared to 24 formerly. The distribution of classes by size is presented in Table IX. 1

(6) Number of Classes. There were, in 1934, 217 classes compared to 163 in the earlier periods. The first figure does not include independent study groups. The change has: been at the Senior college level. The number of classes in the Senior College more than doubled during the five year period. The number in the Junior college remained practically the $\operatorname{sam} \theta$.

c. Conclusion. There is no indication that the faculty load was lightened. While the size of the faculty remained

$1_{\text {Tablo IX., p. } 42}$ 
TABLE IX.

SIZE OF CLASSES

COMPARED FOR FIRST SEMESTER

1930-31 AND 1934-35

\begin{tabular}{|c|c|c|c|c|c|c|}
\hline \multirow{2}{*}{\multicolumn{3}{|c|}{ Size of Class }} & \multicolumn{2}{|c|}{$\frac{\text { Number of classes }}{\text { First Semester }}$} & \multicolumn{2}{|c|}{ Percentage of Classes } \\
\hline & & & $\begin{array}{l}\text { First } \\
1930-31\end{array}$ & $\begin{array}{l}\text { emester } \\
1934-35\end{array}$ & $\begin{array}{c}\text { First } \\
1930-31\end{array}$ & $\left\{\begin{array}{l}\text { emester } \\
1934-35\end{array}\right.$ \\
\hline 266 & & & & 1 & & .0 \\
\hline 197 & & & & $I$ & & .0 \\
\hline 174 & & & & $I$ & & 0 \\
\hline 146 & - & 150 & $I$ & & $I$ & \\
\hline 141 & -1 r r r r r & 145 & & 3 & & $I$ \\
\hline 136 & - & 140 & & 2 & & 1 \\
\hline 131 & -1 & 135 & & & & \\
\hline 126 & -7 - $19+1$ & 130 & & & & \\
\hline 121 & - & 125 & & & & \\
\hline 116 & - & 120 & & & & \\
\hline 111 & -1 & 115 & 2 & & $\underline{I}$ & \\
\hline 106 & -1 & 110 & & & & \\
\hline 101 & -1 & 105 & & 1 & & 0 \\
\hline 96 & - & 100 & & 2 & & 1 \\
\hline 91 & $=$ & 95 & & & & \\
\hline 86 & $=$ & 90 & & & $I$ & \\
\hline 81 & - & 85 & $I$ & & $I$ & \\
\hline 76 & - & 80 & $\overline{2}$ & & 1 & \\
\hline 71 & $=$ & 75 & 1 & $I$ & $\bar{I}$ & 0 \\
\hline 66 & $\overline{-}$ & 70 & 2 & $I$ & I & 0 \\
\hline 61 & $\begin{array}{c}- \\
-\end{array}$ & 65 & & 2 & & 1 \\
\hline 56 & $=$ & 60 & 4 & $I$ & 3 & $\overline{0}$ \\
\hline 51 & - & 65 & 2 & 2 & $I$ & 1 \\
\hline 46 & - & 50 & 3 & 3 & $\overline{2}$ & 1 \\
\hline 41 & $\overline{-}$ & 45 & 5 & 8 & 3 & 4 \\
\hline 36 & - & 40 & 8 & 13 & 5 & 6 \\
\hline 31 & - & 35 & 8 & 14 & 5 & 6 \\
\hline 26 & - & 30 & 25 & 16 & 16 & 7 \\
\hline 21 & - & 25 & 21 & 21 & 12 & 9 \\
\hline 16 & - & 20 & 15 & 24 & 9 & 11 \\
\hline 11 & - & 15 & 25 & 32 & 15 & 14 \\
\hline 6 & - & 10 & 24 & 36 & 14 & 16 \\
\hline 0 & - & 5 & 15 & 44 & 10 & 19 \\
\hline
\end{tabular}

Note: Physical education and freshman survey have not been included in these computations.

Read: In 1930 in both Colleges there were three classes where 111 students or more were enrolled, representing about 2 per cent of all classes. In 1934 there were elght such classes, representing 3 per cent of all classes. 
TABLE X.

DISTRIBUTION OF CLASSES BY SIZE

FOR THE JUNIOR AND SENIOR COLLEGES

FOR THE FIRST SEMESTER 1930-31 AND 1934-35

\begin{tabular}{|c|c|c|c|c|c|}
\hline \multirow{2}{*}{\multicolumn{2}{|c|}{ Size of Class }} & \multicolumn{2}{|c|}{$\begin{array}{c}\text { Number of classes } \\
\text { Junior College }\end{array}$} & \multicolumn{2}{|c|}{$\begin{array}{c}\text { Number of classes } \\
\text { Senior College }\end{array}$} \\
\hline & & $1930-31$ & $1934-35$ & $1930-31$ & $1934-35$ \\
\hline \multicolumn{6}{|l|}{266} \\
\hline \multirow{2}{*}{\multicolumn{6}{|c|}{197}} \\
\hline & & & $I$ & & \\
\hline 146 & -150 & $I$ & & & \\
\hline 141 & -145 & & 3 & & \\
\hline 136 & -140 & & 2 & & \\
\hline 131 & -135 & & & & \\
\hline 126 & -130 & & & & \\
\hline 121 & -125 & & & & \\
\hline 116 & -120 & & & & \\
\hline 111 & -115 & 2 & & & \\
\hline 106 & $=110$ & & & & \\
\hline 101 & -105 & & $I$ & & \\
\hline 96 & -100 & $I$ & 2 & & \\
\hline 91 & -95 & & & & \\
\hline 86 & -90 & & & & \\
\hline 81 & -85 & $I$ & & & \\
\hline 76 & -80 & 2 & & & \\
\hline 71 & -75 & $I$ & 1 & & \\
\hline 66 & -70 & $\bar{Z}$ & I & & \\
\hline 61 & -65 & & 1 & & 1 \\
\hline 56 & -60 & $\overline{2}$ & $\overline{1}$ & 2 & \\
\hline 51 & -55 & 2 & 2 & & \\
\hline 46 & -50 & 3 & 3 & & \\
\hline 41 & -45 & 4 & 5 & 1 & 2 \\
\hline 36 & -40 & $\overline{7}$ & II & $I$ & 2 \\
\hline 31 & -35 & 4 & 13 & 4 & I \\
\hline 26 & -30 & 22 & 12 & 3 & 5 \\
\hline 21 & -25 & 17 & 11 & 4 & 8 \\
\hline 16 & -20 & 9 & 10 & 6 & 13 \\
\hline 11 & -15 & 15 & 9 & 10 & 22 \\
\hline 6 & -10 & 11 & 10 & 13 & 26 \\
\hline 0 & -5 & 4 & 5 & 11 & 40 \\
\hline
\end{tabular}

Note: Physical education and freshman survey have not been included in these computations.

Read: In 1930-31 in the Junior College there were three classes enrolling 111 or more students while in 1934-35 there were eight such classes. There were no classes of this size in the Senior College in either period. 
practicaliy the same, student enroliment in courses was heavier and the number of classes increased. The fact that the per cent of offerings decreased alleviated the burden of extra classes to some degree, but it is doubtful whether it was great enough in face of the other changes to have caused a reduction in the teaching load.

F. From the Viewpoint of Student Retention and Mortality

Any strong reorganizational program is compelled to affect student enrollment one way or the other depending upon its objectives. If the objectives of this program have been correctly interpreted by the writer the effort has been to prolong the general education period and to raise the standards of the Sentor College period. If these objectives have been accomplished their results should be reflected in a greater per cent of retention of freshmen for the sophomore year, due to the emphasis upon a general education, and a greater loss of students after the sophomore year, due to selective processes.

a. Procedure. To determine the status of student retention and mortality between the two periods and at the various levels, students in both periods were grouped into categories described by the number of hours credit which they had earned. These categories were stated at $0,15,30,45,60,75,90,105$, and 120 hours, the student being placed in the category nearest to the number of hours he had earned by the first semester in 
each year. The categories fell at approximately the eight semesters of a college period, the 60 hour one, for example, being that one in which would fall a beginning junior. Then was computed the number of students in each group who had Withdram one and two semesters later. The data that were obtained are presented in Table XI.

TABLE XI.

NUMBER OF STUDENTS ENROLLED AT EACH ACADEMIC

LEVEL COMPARED FOR 1930-31 AND 1934-1935

\begin{tabular}{|c|c|c|c|c|c|c|c|c|c|c|}
\hline & \multicolumn{2}{|c|}{$\begin{array}{l}\text { Fresh- } \\
\operatorname{man}\end{array}$} & \multicolumn{2}{|c|}{$\begin{array}{l}\text { Sopho- } \\
\text { more }\end{array}$} & \multicolumn{2}{|c|}{ Juni or } & \multicolumn{2}{|c|}{ Senior } & \multicolumn{2}{|c|}{ Senior } \\
\hline & & & Hours & 0 & $\operatorname{cres}$ & $11 t$ & Ear. & $1 \theta d$ & & \\
\hline & 0 & 15 & 30 & 45 & 60 & 75 & 90 & 105 & 120 & Total \\
\hline $\begin{array}{l}\text { Number Enrolled } \\
\text { First Semester } \\
1930-1931\end{array}$ & 269 & 71 & 155 & 61 & 108 & 65 & 74 & 27 & 4 & 834 \\
\hline $\begin{array}{l}\text { Number Enrolled } \\
\text { First Semester } \\
1934-1935\end{array}$ & 278 & 93 & 141 & 49 & 123 & 31 & 62 & 26 & 9 & 812 \\
\hline
\end{tabular}

Read: In 1930 there were 269 entering freshmen. In 1934 there were 278 entering freshmen.

b. Findings. Summarizing these findings $\frac{1}{9}$ it will bo found that the results obtained bear out the expectations previously mentioned, the outstanding facts being:

(1) Practicaliy no differences whatsoever between the 
$\underline{\text { TABLE XI }}, \underline{\mathrm{B}}$.

STUDENT MORTALITY AT EACH ACADEMIC LEVEL

COMPARED FOR 1930-1931 AND 1934-1935

\begin{tabular}{|c|ccccccccc|}
\hline & 0 & 15 & 30 & 45 & 60 & 75 & 90 & 105 & 120 \\
\hline \hline $\begin{array}{c}\text { FIRST SEMESTER } \\
\text { Per Cent Withdrawn } \\
\text { In 1930-1931 }\end{array}$ & 21 & 20 & 15 & 21 & 14 & 15 & 9 & 7 & 0 \\
\hline $\begin{array}{c}\text { Per Cent Withdrawn } \\
\text { in 1934-1935 }\end{array}$ & 20 & 21 & 9 & 22 & 12 & 16 & 8 & 9 & 9 \\
\hline $\begin{array}{c}\text { SECOND SEMESTER } \\
\text { Per Cent Withdrawn } \\
\text { in 1930-1931 }\end{array}$ & 44 & 54 & 43 & 49 & 37 & 38 & 11 & 7 & 25 \\
\hline $\begin{array}{c}\text { Per Cent Withdrawn } \\
\text { in 1934-1935 }\end{array}$ & 45 & 36 & 43 & 63 & 49 & 58 & 19 & 35 & 22 \\
\hline
\end{tabular}

${ }^{1}$ Based upon individual case nistories.

Read: (1) Practically no differences whatsoever between the periods in the amount of first semester withdrawals.

(2) More freshmen stay on into the sophomore year, mortality after the freshman year having decreased from 54 per cent to 36 per cent.

(3) More sophomores wi thdraw at the end of the second semester, mortality having increased at this lovel from 49 per cent, to 63 per cent.

(4) Continuing at all of the upper levels, student mortality in the Senior College continues to be sightly greater.

(5) of no significance to the comparison between periods but of general interest is the fact that withdrawals at the mid-year tend to range from 50 to 125 per cent less than after the second semester. 
periods in the amount of first semester withdrawals. These withdrawals, it is especially pointed out, would be those taking place in the mid-year.

(2) Withdrawals at the mid-year are from 50 per cent to 125 per cent less than after the second semester.

(3) More freshmen stay on into the sophomore year, retention after the freshman year having increased from 36 per cent to 54 per cent.

(4) More sophomores withdraw at the end of the second semester, mortality having increased at this level from 49 per cent to 63 per cent.

(5) Continuing at all of the upper Senfor College levels, student mortality in the Senior College continues to be slightly greater.

\section{Chapter Summary}

G. The Status of the Curriculum in 1934-1935

Summarizing in a very general way, it may be said that reorganization in the College affected the program of studies both quantitatively and qualitatively. The evidence presented in this chapter demonstrated a reduced number of offerings. Many courses were withdram and others introduced, causing a turnover in curriculum of approximately 80 per cent of the original offerings. The greatest changes occurred in the Senior College. It absorbed 80 per cent of the new courses, practically doubling the total number of classes and tripling 
the number of very small classes. The traditionally academic type of offering remained the dominant one.

But the trend in curriculum changes was away from the traditionaliy academic towards general education, integration, elimination of duplications, provisions for the superior student, for life needs, for vocational training, and for civic education.

Whether due to the changes in curriculum or social changes in the modern world, the shift in enrollments in departments and divisions was phenomenal. The social sciences division showed the greatest gain. Again it is in the Senior College that the greatest shifts were evident. While humanities onrollments remained at a standstill, there were gains of 95 per cent and 75 per cent respectively in the social sciences and natural sciences divisions.

Students in the Junior College were not permitted a great number of electives, but Senior College students had a program rich in electives including a wide range of subjects and objectives.

All of these changes in curriculum were managed without any increase in the size of the faculty or in the number of offerings. But the number of classes increased, especially in the Sentor College in the small class range. 
Chapter II. THE AREA OF INDIVIDUALI ZING THE STUDENT

A. Introduction. In reorganization great stress was placed upon the individual student. The student was looked upon as a variable factor, for whom provisions were to be made that would be adaptable to his interests and abilities. The means taken to realize this end were administered through the curriculum, through the advisory system, and through methods of instruction. The College has never been equipped in such manner that it could evaluate the real growth of individuals. Only indirectly through the measurement of achievement and through the expression of student and faculty opinion has it been possible to evaluate the instruments that have been employed to promote individual growth. In a sense the College devotes its whole self to the individual, so that it becomes difficult to separate steps and label them for the individual.

The purpose of this chapter will be, then, to describe only the most outstanding steps that were taken by way of providing for the individual.

B. The Instruments of Individualization

The General Curriculum. The most revolutionary measure was the establishment of a "General Curriculum" Division. In Its earliest conception the General Curriculum Division was known as the Social Intelligence Division. The Division was 
designed primarily for those students who through lack of ability or preparation could not do the Senior College work but who could benefit from a further semester or two in college, undertaking work fitted to their level. It was the original intention to designate for the Curriculum special Junior College courses such as public speaking, dramatic art, or survey of the home, and to add other courses, such as a series of courses in recreational supervision, which would supply a core of "easy" electives of a nature from which the student might benefit. However, the Social Intelligence Division earned for itself within a year's time such an odium in the minds of students, due perhaps to the unwise inclusion of the word "intelligence" in its title, that the faculty recommended a change of name to "General Curriculum."

As the term "General Curriculum" was used in 1934-35 it embraced all Junior College courses, rather than special ones as did the Social Intelligence Division. Enrolled therein were those students who ordinarily should have been pursuing Senior college studies but who in the estimation of the Senior College Admission Committee did not have the requisite standing for that $\operatorname{colleg} \theta$. Moreover, in 1934-35, there were. no special classes added, due partly to lack of agreement as to what courses to provide and lack of a staff to administer them. However, in 1934-35, students relegated to General Curriculum were allowed to pursue Senior College courses in a special field where their ability had been proved. By 
this latter arrangement, several girls, for instance, who could not meet the Senior College standards did carry advanced work in home economics. The General Curriculum as it stood in 1934-35 may be thought of as a provision for allowing students an extended probationary period in college. This statement is especially applicable for those individual cases where the student, through lack of scholastic adjustment, iliness, or other factors, had failed in his freshman year but had recovered enough in his second year to give promise of benefitting by further atay in College.

Probation Dismissal. It should be pointed out that the General Curriculum was not a catch-all for all falling students. Each case was acted upon by an Executive Committee and treated according to its best discretion. The Committee had at its hands the alternative measures of dismissal and probation. The "probation" measure did not in any way limit the kind of work a student might do, although it often stipulated the amount of work. Probation was a sterner measure than relegation to the General Curriculum in that it set certain standards which the student was required to meet or he would automatically be dismissed. Probation was used more often in the cases of capable students who, the Committee felt, could benefit from college but who showed too great disposition to stray into the "side-shows." Probation carried a second penalty, the 
exclusion of the student from all campus activities. Probation students were on the whole a more capable group than the General Curriculum students. The General Curriculum student was not barred from campus activities, because it was thought that herein lay, probably, the only benefits he could be expected to derive from his college attendance.

Dismissal was applied in extreme cases where the student displayed entire lack of interest in his work. Dismissal, in such instances, was of ten a great relief to the student, as in those cases where the student was forced to remain in college because his parents wished him to do so. Dismissal was almost always resorted to in those cases where the student failed in all work carrled, unless some very extenuating circumstances were proved.

Senior College Standards. The Introduction of Senior College standards, which will be discussed at length in the next chapter, was also a step towards individualizing the curriculum, both in its elimination of the unprepared and the resultant standard of work made possible for the selected group. Contradictorily the greater homogeneity of the Senior College group was in the direction of individualization, since it made possible a type of instruction and curriculum more nearly correlated with this higher type of student. Independent Study. The first courses in independent study were offered in the sumer of 1932. By 1934 practically all departments were offering such courses. The independent 
study course was open only for students who had unusual ability or who had made unusual progress in the particular field. The independent study course was not offered, as was thought at first, as a convenience course to persons who needed particular credit, or who wished to take courses out of season. These courses were generally problematical in character. The method of administration included registration in the course, agreement between instructor and student upon a topic and a method, and oral examination by an external group in which the instructor of the course participated.

A summary of the amount of independent study courses and the departments in which it was offered has been made and is presented in Tables XII and XIII.

Students stated why they enrolled for independent study. Their motives as they stated them are listed in the Appendix. ${ }^{1}$ The courses that were taken last year are included in the Appendix. 2

Extra-mural Study. Extra-mural study was a further provision for independent study. The extra-mural work was a "convenience" measure for those students who wished to fulfill college requirements through their own independent efforts. The student registered for extra-mural study, but he had no particular instructor. When he felt that he was 
TABLE XII.

ENROLLMENTS IN INDEPENDENT STUDY

SUMMER SCHOOL 1932 TO JUNE 1935

\begin{tabular}{|c|c|}
\hline Total Number of Courses & 67 \\
\hline Total Number of Students & 56 \\
\hline Hours Carried & 146 \\
\hline $\begin{array}{c}\text { Hours Passed (3 hrs. Incomplete) } \\
\text { Total Number of Students Who } \\
\text { Continued in the Second Semester }\end{array}$ & 143 \\
\hline $\begin{array}{c}\text { Grades Awarded: A } \\
\text { B }\end{array}$ & 7 \\
\hline C & 64 hours \\
\hline D & 11 hours \\
\hline I & 2 hours \\
\hline
\end{tabular}

TABLE XIII.

DISTRI BUTION OF INDEPENDENT STUDY COURSES BY DEPARTMENTS SUMMER SCHOOL 1932 TO JUNE 1935

\begin{tabular}{|l|r|}
\hline Department & Courses \\
\hline \hline Biology & 15 \\
\hline Chemistry & 2 \\
\hline Econom1cs & 10 \\
\hline Education & 6 \\
\hline English & 6 \\
\hline French & 1 \\
\hline General & 6 \\
\hline German & 3 \\
\hline Home Economics & 1 \\
\hline History & 8 \\
\hline Polltical Science & 3 \\
\hline Philosophy and Psychology & 4 \\
\hline Mathematics & 2 \\
\hline
\end{tabular}


prepared in his subject, he submitted himself for examination by a committer named by the dean. Credit and grade for the amount and quality of the achievement were allotted by this committee. The purpose of extra-mural study was partly to free from class routine students who preferred independent work and partly to allow credit for work of college character which might not necessarily have been taken in cursu. One Mexican student who had taught French and Spanish in Mexican schools gained a large amount of extramural credit in romance languages. An adult student who had taught social studies in the local high school for many years, and who was thoroughly competent in that field, covered a large part of her credit toward the A.B. degree through extra-mural examinations.

Entrance Examination. While in the earlier period entrance to the College to pursue courses for the degree was granted only to those students who presented the stipulated credentials from high school, by 1934 adult atudents who, through experience or study in other colleges, seemed to meet the level of high school achlevement were permitted to satisfy this requirement by examination. In such cases the student was expected to achieve a standing on the tests which was equivalent to the standard form for high school seniors. Several students, all adults, were accepted on this basis.

In September, 1934, the College admitted, with the 
special permission of the Southern Association, thirteen high school students who had not completed their high school courses but who demonstrated what the college thought to be sufficient ability for carrying college work. These persons were all superior persons who were able to demonstrate achievement on the College placement tests equivalent to that of the average entering student. The students did successful college work, which was, furthermore, as "successful" as that done by a control group of regular freshmen of similar aptitudes. ${ }^{1}$ In September 1935, a second group was admitted and permission was obtained from the Southem Association to extend the experiment for another two years. The primary purposes of this experiment were to provide for superior students a more challenging type of intellectual offering and to allow them to benefit from their aptitudes by an accelerated type of education.

\section{$I_{\text {TABLE XIV }}$}

COMPARISON OF EXPERIMENTAL AND CONTROL GROUPS OF FRESHMEN UNDER PLAN OF SOUTHERN ASSOCIATION OF COLLEGES AND SECONDARY SCHOOLS

1934-1935

\begin{tabular}{|c|c|c|c|c|c|}
\hline & $\begin{array}{c}\text { No. of } \\
\text { First } \\
\text { First } \\
\text { 6reks }\end{array}$ & $\begin{array}{c}\text { Polnt } \\
\text { Standing } \\
\text { First } \\
\text { Semester }\end{array}$ & $\begin{array}{c}\text { Point } \\
\text { Standing } \\
\text { Second } \\
\text { Semester }\end{array}$ & $\begin{array}{c}\text { Hours of } \\
\text { Library } \\
\text { Study } \\
\text { lst Sem. }\end{array}$ & $\begin{array}{c}\text { Hours in } \\
\text { Extra-Curr. } \\
\text { Org'tions } \\
\text { lst. Sem }\end{array}$ \\
\hline $\begin{array}{l}\text { Experi- } \\
\text { mentals }\end{array}$ & 6 & 1.59 & 1.37 & 249 & 275 \\
\hline Controls & 11 & 1.52 & 1.40 & 301 & 346 \\
\hline
\end{tabular}


The Advisory System. One of the earliest institutions in the reorganizational period was an advisory system, which provided every student with an adviser from the time of his entrance into the College. Steps were taken to see that the student met his adviser at least six times during the year. Four times a year he went to his adviser to recelve his grades in courses, and the other two times he went to him for advice with his schedule at the beginning of the semesters. The adviser, when the student visited him, had in his possession not only the grades which were given to the student by all of his instructors for the period, but also the personnel folder of the student. This folder contalned his College record of courses taken and grades in them, his aptitude and achievement test record, and other miscellaneous information concerning his vocational intentions, his health record from the College physician, and the 11ke. The advisers were requested to record on the folder any information that they obtained from the student which they felt pertained to his individual success.

Six Week's Grades. For the benefit of the student and to promote achievement in the College generally, definite periods were set up throughout the year in which it was made known to students the progress which they had made in their work. The ideas of motivation and competition, it was expected, would play their parts in keeping achievement at a higher and more consistent level than under a system where 
the student learned his standing in his course only at the end of the semester.

Vocational Lectures. Vocational lectures in the professional flelds and in several of the other important fields of choice of students were given annually. There was no credit allowed for these lectures, and attendance was optional. Lectures were scheduled in a manner that made it possible for a student to attend all of them if he wished. The addresses were made by the deans of the schools of the University or by citizens prominent in their special lines of work.

Mental Hyglene. Although the College has never had a full-time or even half-time peychiatrist, it has had in cases of special need the colperation of the psychlatrist connected with the School of Medicine. The college physician has also been of service in prescribing for these special cases. Freshman Personnel Blank. Entering freshmen were asked to fill in a detalled questionnaire pertaining to their activities before entering the college. Provision was made for questions on the home, relatives, high school extracurriculum activities, the usual data on age, residence, guardian, etc. The questions asked required completely objective responses on rocational plans, special advice neoded, honors, and the like. During the years following its first use the questionnalre was revised from time to time as seemed appropriate. The questionnalre has been and is being used by advisers in becoming better acquainted with 
the student, by the Dean's Office in recording the past record of the student, by the dean of romen in becoming better acqualnted with the women students, and frequently for data that have a bearing on certain studies carried on in the Research Office. Since 1932, practically all of the responses on the questionnaire have been recorded on the Accumulative Personnel Folder, which has been a great added convenience to the persons making use of the materials it contains. Persons who have used the blank often express the wish that there were some more subjective evidence of the student's Intellectual activities in the past, such as that of the type that might be obtained through autobiographical sketches. Freshman Advisers. For the first time in September, 1930, entering freshmen were assigned to advisers. Advisers were selected on the basis of the interest they had shown previously in the welfare of freshman students. About fifteen advisers made up the first group. The freshman first met his adviser at the time of registration. This adviser continued to be his adviser throughout the junior college years, unless the student particularly requested a transfer. In the following years the original group of fifteen advisers was enlarged, so that no one teacher carried an extra load of advisees. Advisers were assigned by the chairman of the personnel committee. About ten advisees to one instructor was the ratio. The adviser approved the student's program of studies, met him six times a year during the grading periods to talk over his progress in school work and campus 
activities and as many other times as the student desired. The advisers were requested to record interviews with the students on the personnel folders, but it cannot be reported at this time that they did this faithfully. This omission cannot be ascribed to inconvenience in procuring the folder, as the folders were deposited four times yearly at the times of regular conference periods scheduled for student and adviser, in the offices of the faculty adviser. Rather the reluctance to inscribe on the card seemed to be linked with the idea that the adviser felt that he was betraying a confidence when he wrote personal information which the student might have confided to him. There seemed to be some justification for this feeling on the part of the teachers, since it appears that no attempt was made to keop the folder from falling into the hands of the student who might then see what had been written thereon, and secondly, that it was a known fact that the student's personnel cards passed through the hands of many student employees in the Dean's office with doubtful consequences.

One remedy ouggested is the employment of a full time recorder to be entrusted with the work of these cards. This person might also be charged with keeping in touch with all sources of information for news of student participation in events. An additional safeguard would be to send the card, when .1t becomes necessary to entrust it to the student, to faculty members in a sealed envelope with the request that 
it be returned in similar form. Recent case studies made for a group of twenty students in the College by a class in educational guidance were so revealing in the insight they afforded into the backgrounds of the respective students that one can scarcely understand how we can ever hope to make the best provision for our students without taking into account thorough case studies of individuals. Tutoring. During the first semester of each year tutoring was available to beginning students without charge. The tutors were members of the Methods of Teaching class. The purpose of tutoring was, primarily, the experience it afforded the senior student in teaching rather than the benefit gained by the person tutored.

Fulfillment of Examinations. The use of examinations such as the language qualification, the sophomore comprehensives, and the major and divisional examinations was in a large sense a means of assuring the attainment of a minimum knowledge in the fields tested. It was in a sense an insurance against complete 1gnorance in the important areas of human thought. It also provided an adaptation of pace of study to Individuals; for example, in the case of languages it became possible for some students to fulfill in two semesters what formerly required six semesters.

The Survey Course. Besides serving its purpose in the name of culture and the acquirement of the fundamentals in a fleld, the survey course also served the individual in 
that it made possible for him an over-view of the fields of study and, it was hoped, crystallized for him a cholce of a major field.

Affiliation with the Educational Records Bureau. On November 7, 1932, the College purchased its first membership In the Educational Records Bureau and has since maintained it. One of the advantages that resulted was the testing by the Bureau of students in the New York region who desired admission to the college. The College had annually a number of students in the eastern region apply for admission to the College. With the test results on the student submitted to the College beforehand it became possible for the College to act upon such cases with greater confidence for the protection of both the institution and the individual concerned. Placement Tests. In 1934 placement tests were being used in the forelgn languages, in the English sections, in biology, and in chemistry. The results of the use of the tests in forelgn languages were both to accelerate and to retard the progress of atudents who enrolled in those departments. It was possible for a student, for example, who had had two years of French in high school to enter upon the third year of college French if his achievement seemed to justify it, or to be started again in the beginning French class if he demonstrated that he was unprepared. In English three divisions of achievement were recognized and methods of instruction adapted to the needs of the three levels. In 
biology and chemistry students were advised to enter advanced sections if their progress seemed to warrant it, this being especially true in the cases of the pre-medical and pre-dental students.

$$
\text { C. Summary }
$$

Special provisions made for the individual have emphasized principalig the provision of opportunities for the superior student through selective Senior College admissions, entrance examinations, independent study and extra-mural study, and more suitable types of instruction through sectioning by placement tests. Provisions for other students were effected principally through closer contact with the faculty adviser and amore sympathetic handing of descriptive cases utilizing more informative records. 
Chapter III. THE SENIOR COLLEGE

A. Introduction. Reorganization in the Senior College was more than a matter of revising the curriculum. There were also involved questions concerning the quality of ability required for successful completion of its curriculum, the difference in methods from the Junior College, the various roles played by divisions and departments, and the various issues that arose about these central problems. The a im of this chapter will be to set forth the change in the Senior College along with the accompanying considerations.

\section{B. Questions}

a. What have been the objectives of the Senior College? It has already been shown that the reorganization of the Sentor College has been the most important phase of the five-year period. Reorganization here has emphasized a higher standard of work to be brought about (1) through a curriculum closer knit and better integrated; (2) through selection of Senior College students; (3) a break with the idea of credits earned, by substitution of major and general college comprehensive examinations; and (4) génerally greater expectation of student achievement. b. What changes have occurred in the curriculum? From the viewpoint of objectives it will be found from Table IV ${ }^{l}$ that the objectives most stressed in

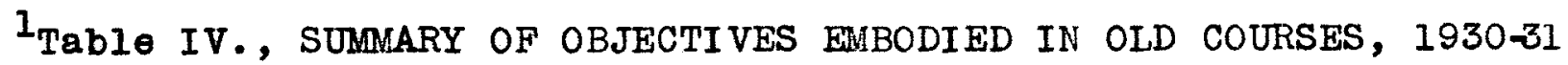
p. 28 . 
the old Sentor College curriculum were, in the order mentioned, the traditionally academic, the vocational, and the interpretation of the modern world. The first objective was about three times more prevalent than the last. By reference to Table $V^{l}$ it will be found that the objectives of the offerings in 1934-1935, in the order of emphasis, are the liberalizing and cultural or the traditionally academic, the rocational, and life needs or the understanding of self. The chlef alms, as they were embodied in offerings, it may be said, then, remained practicaliy the same in 1934-35 as in 1930-31. The important changes, revealed only by a closer study of actual frequencies, were an increase of the offerings for superior students, the number of courses definitely offered for this group having increased from five to seventeen; a gain in vocational offerings from thirty-two courses to fifty-five courses. There were in 1934-35 six courses organized for the definite purpose of integrating the fields of knowledge, where formerly there were none. It may be said, then, that while the main body of aims remalned about the same for the bulk of offerings, certain new objectives were also being met. Whether the ratio of the old to the new was as large as was desirable was not answered by any of these analyses. It is merely pointed out that they have occurred in some measure.

The measures that were taken to achieve a more integrated

$1_{\text {Table }}$., SUMMARY TABLE OF OBJECTIVES EMBODIED IN PRESENT OFFERIN GS, 1934-35, p. 29. 
program of studies for the Senior College student deserve particular mention. General examinations over the entire college curricula, over the major, and over the divisional fleld were introduced as a means of freeing the College from the credit-earning idea of education. The introduction of special colrdinating courses for several majors and for each division were steps towards integrating the work of each division. The requirement that a certain proportion of the rork of any major be outside his major but within his division, it was hoped, would yield greater coherence to and understanding of the major subject. To safeguard too great specialization in any one division the student was required to elect work in another division than that of the major. The result of the latter requirement may be read in Table VI ${ }^{1}$ where the scattering of course registrations in 1934-35 over the entire list of offerings may be contrasted with certain concentrations of the earlier period. c. What were the changes in department and division enroliments?

Regardless of what phenomena have caused them, there were striking changes in enrollments both by divisions and by departments. There formerly the division of the humanities had the greatest enrollment, it had the least in 1934-35. The social sciences division had the greatest enrollment in the 1934-35 period, its enrollment having

$1_{\text {Table }}$ VI., CHANGES IN COURSE REGISTRATIONS, p. 31. 
practically doubled during the reorganization period. The onroliment in the division of the humanities remained practically at a standstill, over the five years while that of the division of social sclences has increased 95 per cent and that of the division of natural sciences increased 73 per cent. The increase in the enrollments in the departments of education and sociology and the addition of the department of political sciences account for the greatest gains in the division of social sciences. The registration in history remained practically the same, despite the addition of the department of political sciences, which enrolied practically the same number of students as history. In the division of the natural sciences both biology and chemistry practically doubled in the amount of enrollments over those of the earlier period. The addition of the cobrdinating course for majors in science also added numbers to this department. In the division of humanities, the two largest departments, English and romance languages, showed losses in enrollment. These losses were recovered for the division by the increase in the enrollment in the "humanities" course. There were no gain however, for the shift of Junior College enroliment of the earlier period into the Senior College seemed to be away from specialization in departments and definitely towards the non-specialized, broadly cultural reading work.

d. What were the changes in standards of judging grades? 
To evaluate fully such a change it would be necessary to have many data which do not exist. For instance, there are no records of aptitudes of entering classes until september, 1930. Sophomore comprehensives were not given until May, 1932. It seems out of reason to measure in any way the quality of written work required formerly from Senior college students with that required now, as such evaluations were not made formerly or records kept of either the quality or quantity of the earlier work. The quality point standing of sentors during both periods can have no direct bearing upon the issue because the quality of the work has changed, which can and will be demonetrated here in some measure. With technical difficulties of the type enumerated preventing a thorough evaluation, and with full realization of the questionableness of a comparison unattended by carefully controlled groups from both periods, certain studies have been made.

From a tabulation comparing the number of $A B C D F$ grades received by seniors in 1930-31 and seniors in 1934-35 no wide difference of distributions was found. ${ }^{l}$

Moreover, there is no statistically significant difference between the general quality point standing of 1.575 for the seniors of $1930-31$ and that of 1.395 for the seniors of $1934-35 .^{2}$

$1_{\text {See }}$ Table XV., page 68.

${ }^{2}$ See Table XVI., page 68 . 
TABLE XV.

PER CENT OF LETTER GRADES RECEIVED BY SENIORS

IN 1930-1931 AND 1934-1935 COMPARED

\begin{tabular}{|l|c|c|c|l|l|}
\hline & A & B & C & D & F \\
\hline Sen1ors 1930-1931 & $16 \%$ & $40 \%$ & $33 \%$ & $10 \%$ & $1 \%$ \\
\hline Sen1ors 1934-1935 & $19 \%$ & $37 \%$ & $36 \%$ & $7 \%$ & $1 \%$ \\
\hline
\end{tabular}

Read: In 1930, 16 per cent of sentors' grades were "A," while in 1934, 19 per cent were "A."

TABLE XVI.

GENERAI POINT AVERAGES AND STANDINGS ON COLLEGE

ACHI EVEMENT TEST COMPARED FOR SENIORS OF

1930-1931 AND 1934-1935

\begin{tabular}{|c|c|c|c|c|c|c|c|}
\hline $\begin{array}{c}\text { General } \\
\text { Point } \\
\text { Average } \\
\end{array}$ & $Q_{1}$ & $\mathrm{Q}_{2}$ & $Q_{3}$ & 6 dist. & Mean & $\begin{array}{c}6 \\
\text { Median }\end{array}$ & $\begin{array}{l}6 \text { diff } \\
\text { Median }\end{array}$ \\
\hline $1930-1931$ & 1.11 & 1.58 & 2.06 & .46 & 1.64 & .06 & \multirow{2}{*}{.26} \\
\hline $1934-1935$ & 1.32 & 1.40 & 1.93 & .56 & 1.65 & .01 & \\
\hline $\begin{array}{l}\text { College } \\
\text { Achievement } \\
\text { Test }\end{array}$ & $Q_{1}$ & $Q_{2}$ & $Q_{3}$ & 6 dist. & Mean & $\begin{array}{c}6 \\
\text { median }\end{array}$ & $\begin{array}{l}6 \text { diff } \\
\text { Median } \\
\end{array}$ \\
\hline $1930-1931$ & 197 & 451 & 682 & 241 & 418 & 36 & \multirow[t]{2}{*}{37} \\
\hline $1934-1935$ & 642 & 846 & 949 & 47 & 586 & 62 & \\
\hline
\end{tabular}


On the other hand, the normative basis ${ }^{l}$ marking median achievement for the 1930-31 senlors was the forty-fifth percentile compared to the eighty-fourth for the seniors of 1934-35, which is a statistically significant difference. Similar improvement was demonstrated in the placement of the quartile points.

The College Achievement Test has come to be accepted in the College as a very sensitive instrument of measurement of changed curriculum practice. The order of correlation between grades of the 1931 graduating seniors and their scores on the College Achlevement Test was .18; for seniors in 1935 it was .70. Assuming that the College Achlevement Test was a good rating device, and knowing that grades recelved by seniors were of practically the same quality in the two periods under discussion and that performance on the test changed very significantly in favor of the 1934-35 class, the conclusion may be drawn that the basis for grading seniors changed significantly, al though the grades did not. Seniors in 1934-35 recelved the same quality of grades as sentors in the earlier period, although they really demonstrated greater attainment in knowledge. The difference in the order of correlation is an indication that the faculty adjusted grades better to the degree of attainment. This, indeed, is a most outstanding accomplishment. The particular interest of the foregoing points is that they demonstrate

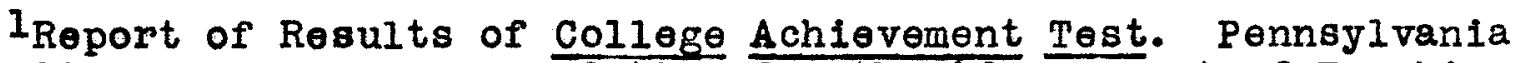
Study by Carnegie Foundation for the Advancement of Teaching. 
that no evaluation of difference can be obtained simply by comparing the quality of grades awarded in the two periods. This fact is presented more strikingly in the distributions of national percentiles on the College Achievement Test for the two periods ${ }^{1}$ in which, it is repeated, there was actually no difference in the quality of grades.

o. What was the effect of applying discriminatory procedures in selecting Senlor College students?

The Plan of Admission to Sentor College. During May of each year beginning in 1934, all of the National Sophomore tests were given. There also were given sophomore comprehensive examinations that were locally constructed and that covered the five major Junior College flelds. While there was a significant degree of correlation between the scores on the national and local sophomore tests, the tests were quite different in many respects. The fact that the correlation coefficients given in Table XVII ${ }^{2}$ are not extremely high is indicative of comprehensiveness rather than of disagreement between the tests.

The passing of comprehensive examinations in six fields was stated in the Catalog as part of the requirements for admission to the Senior College. The standards and policies governing these admissions to Senior College were determined by the faculty of the college through the Committee on Senior College Admissions.

$1_{\text {See }}$ Figure 1, p. 71

$2_{\text {See }}$ Table XVII., p. 72 
FT GURE I.

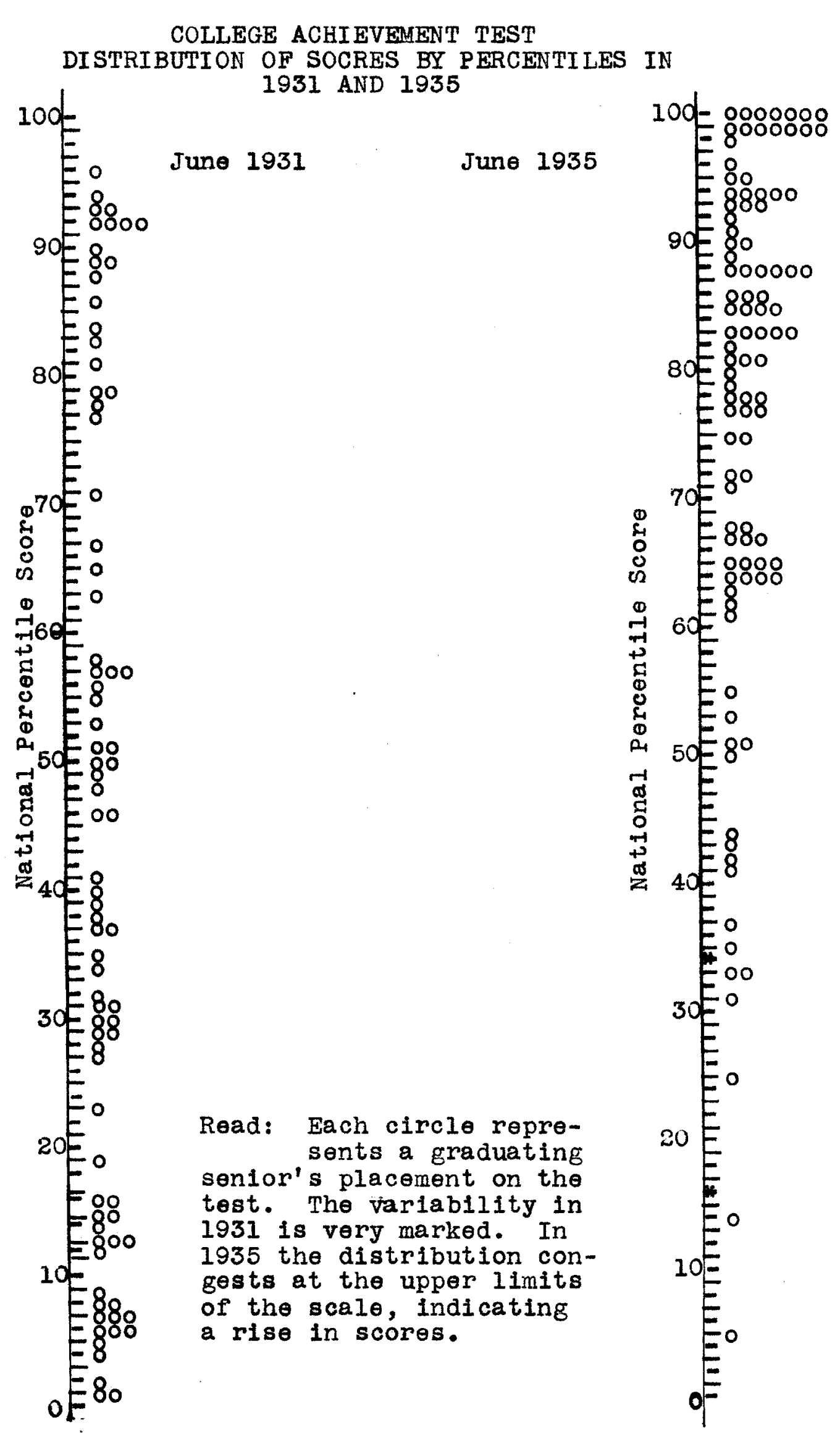


TABLE XVII.

INTERCORRELATION OF SOME OF THE SECTIONS OF THE COÖPERATIVE NATIONAL SOPHOMORE TESTS AND OF SOME OF THE NATIONAL TESTS

WITH LOCAL SOPHOMORE TESTSI

\begin{tabular}{|c|c|c|c|}
\hline$x$ & $\mathrm{y}$ & $r$ & $P \cdot E \cdot r$ \\
\hline $\begin{array}{l}\text { Foreign } \\
\text { Literature }\end{array}$ & $\begin{array}{l}\text { Literary } \\
\text { Acquaintance }\end{array}$ & .87 & \pm .01 \\
\hline $\begin{array}{l}\text { Literary } \\
\text { Acquaintance }\end{array}$ & $\begin{array}{l}\text { Fine } \\
\text { Arts }\end{array}$ & .72 & +.03 \\
\hline $\begin{array}{l}\text { Foreign } \\
\text { Literature }\end{array}$ & $\begin{array}{l}\text { Fine } \\
\text { Arts }\end{array}$ & .77 & +.02 \\
\hline $\begin{array}{l}\text { Total } \\
\text { Humanitios }\end{array}$ & $\begin{array}{l}\text { Fing } \\
\text { Arts }\end{array}$ & .72 & +.03 \\
\hline $\begin{array}{l}\text { Foreign } \\
\text { Literature }\end{array}$ & $\begin{array}{l}\text { Total } \\
\text { Humanities }\end{array}$ & .71 & $:+.03$ \\
\hline $\begin{array}{l}\text { Total } \\
\text { Humanities }\end{array}$ & $\begin{array}{l}\text { Literary } \\
\text { Acquaintance }\end{array}$ & .68 & $* .03$ \\
\hline $\begin{array}{l}\text { Local Natural } \\
\text { Sclences }\end{array}$ & $\begin{array}{l}\text { Codperative } \\
\text { General Sclence }\end{array}$ & .74 & +.03 \\
\hline $\begin{array}{l}\text { Local Social } \\
\text { Sciences }\end{array}$ & $\begin{array}{l}\text { Cooperative } \\
\text { Contemporary Affair }\end{array}$ & .59 & +.04 \\
\hline $\begin{array}{l}\text { Local Social } \\
\text { Sclences }\end{array}$ & $\begin{array}{l}\text { Codperative History } \\
\text { and Social sciences }\end{array}$ & .68 & +.03 \\
\hline
\end{tabular}

In 1935 the Committee ruled that the student must make a percentile rank of 25 (national) on any national test given and a percentile rank of 15 (10cal, of course) on the local test to satisfy the examination requirement in any single fleld.

The fields in which students were required to take examinations, the tests used and the standerd set up by the Committee are presented diagrammatically. 2

IData from 1935 testing. 2Se日 p. 73 
CRITERIA FOR SENIOR COLLEGE ADMISSIONS, JUNE 1935

\begin{tabular}{|c|c|c|c|}
\hline FI ELDS & NATIONAL TESTS & LOCAI TESTS & $\begin{array}{l}\text { MINIMUM } \\
\text { STANDARD } \\
\text { FOR PASSING }\end{array}$ \\
\hline $\begin{array}{l}\text { HISTORY OF } \\
\text { CIVILIZATION } \\
\text { I }\end{array}$ & $\frac{\text { Codperative World }}{\text { History }}$ & History of & $\begin{array}{l}\text { National percentile } \\
\text { of } 25 \text { on national and } \\
\text { local percentile of } \\
15 \text { on local }\end{array}$ \\
\hline $\begin{array}{l}\text { SURVEY OF } \\
\text { THE SOCIAL } \\
\text { SCIEN CES } \\
\quad \text { II }\end{array}$ & 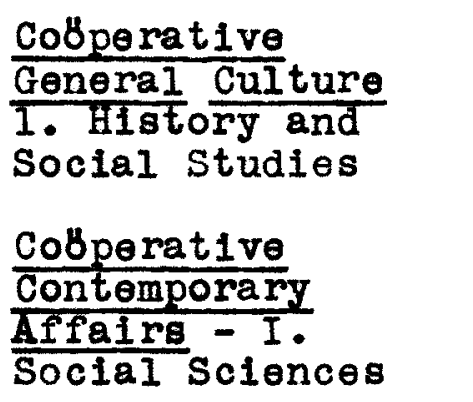 & $\begin{array}{l}\frac{\text { Survey of }}{\text { the }} \text { Social } \\
\text { Sciences }\end{array}$ & $\begin{array}{l}\text { The two nationals } \\
\text { must average a } \\
\text { national percentile } \\
\text { of } 25 \text { and a local } \\
\text { percentile of } 15 \\
\text { is required on the } \\
\text { local }\end{array}$ \\
\hline $\begin{array}{c}\text { ENGLISH } \\
\text { III }\end{array}$ & $\begin{array}{l}\text { Cobperative } \\
\text { English }\end{array}$ & $\begin{array}{l}\text { English } \\
\text { Composition }\end{array}$ & $\begin{array}{l}\text { National percentile } \\
\text { of } 25 \text { on national } \\
\text { and local percentile } \\
\text { of } 15 \text { on local }\end{array}$ \\
\hline $\begin{array}{l}\text { SURVEY OF } \\
\text { THE } \\
\text { HUMANITIES } \\
\text { IV }\end{array}$ & $\begin{array}{l}\frac{\text { Cobperative }}{\text { General }} \frac{\text { Culture }}{\text { Forelgn }} \\
\frac{\text { Literature }}{\text { Cobperative }} \\
\frac{\text { Literary }}{\text { Acquaintance }} \\
\frac{\text { Cobperative }}{\text { General Culture }}\end{array}$ & $\frac{\text { Humanities }}{\text { Survey }}$ & $\begin{array}{l}\text { The three national } \\
\text { tests must average } \\
\text { a national percen- } \\
\text { tile of } 25 \text { and a } \\
\text { local percentile of } \\
\text { l5 is required on } \\
\text { the local }\end{array}$ \\
\hline 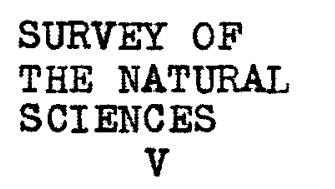 & $\begin{array}{l}\text { Cobperative } \\
\text { General Science }\end{array}$ & $\frac{\frac{\text { Natural }}{\text { Sclences }}}{\text { Survey }}$ & $\begin{array}{l}\text { National percentile } \\
\text { of } 25 \text { on national } \\
\text { and local percentile } \\
\text { of } 15 \text { on local }\end{array}$ \\
\hline $\begin{array}{l}\text { CONTEMPORARY } \\
\text { AFFAIRS }\end{array}$ & $\frac{\text { Cobperative }}{\text { Contemporary }}$ & & $\begin{array}{l}\text { A national percen- } \\
\text { tile of } 25\end{array}$ \\
\hline
\end{tabular}


Administration of the Plan. Students who had the requisite point standing of 1.00 and had not failed in more than two fields of the examinations were automatically admitted to Senior College - unconditionally if there were no fallures, "with condition" or "with conditions" if there were one or more fallures. The "conditions" had to be fulfilled the next year by passing the examination in the fields falled.

For the remaining cases, that is -

(a) those who passed all examinations and did not have the requisite point standing, or

(b) those who had the requisite standing, but failed more than two of the examinations, or

(c) border-ine cases of point standing - those who "just missed," or

(d) those who failed examinations and al so lacked the requisite standing -

all personnel data that were on hand in the office of the Dean ${ }^{1}$ were placed in the hands of the Committee, which considered each of the remaining cases as an individual problem. No strict rules were adhered to, but the Committee did follow a pattern of a sort in making its decisions. In (a), as above, cases the usual procedure was to admit the student to Senior College on probation. In extreme cases the student was dismissed for a

${ }^{1}$ The cumulative college record card of the American Council was used. 
semester or limited to work in the General Curriculum for a temporary probation period.

In (b) cases the student was never dismissed. Depending upon his aptitude and disposition, he was either admitted and advised to review his fields for the next examinations or he was not admitted and advised to take Junior College work, regularly or as auditor, that would be helpful to him at the next examinations. In (c) cases, there could be no pattern. Border-line cases were always the most difficult, and the decisions of the Committee had to rest wholly upon the pertinent circumstances.

In (d) cases, there were a few dismissals, but the general tendency was to allow the student to continue in the General Curriculum as long as he seemed to be benefitting. Special permission occasionally was authorized for advanced work in a particular field in which the student had been successful, as in home economics, physical education, commerce, etc.

The decieions of the Committee cannot be fully appreciated unless the significance of the General Curriculum is understood. The General Curriculum embraced all of the work of Junior College level, but it was generally understood that at any time the student could fulfill the entrance requirements for the Senior College it was his privilege to do so. 
Success of the Plan. The plan has not boen in effect long enough for a really thorough investigation of its effectiveness. The first class affected was the sophomore class of 1933-34. Their scholastic records as of their junior year, 1934-35, are shown in Table XVIII! The conclusion may be dram that the plan followed by the committee in defining these groups drew good lines of distinction among them. These findings were not by any means considered final. Further, the data in Table XVIII ${ }^{l}$ showed that the group admitted unconditionally (because they had 1.00 standings, 60 hours, and passed all tests) made a scholastic standing of 1.6 , which is considerably higher than that required for graduation and quite high for any group. The greater portion of their work was, of course, carried at Senior College level. The eecond group, those who were admitted provisionally because they lacked a few quality points or had failed either one or two of the tests, maintained a 1.2 average with the greater portion of work, but not as much as in the first group, carried at Senior college level. The third group, those not admitted because they falled more than two tests, failed to make a 1.00 average in elther of their junior semesters. The majority of their work was restricted to the Junior College level. The exact figures for each group of students may be found in Table XVIII ${ }^{l}$ which also gives other supplementary statistics. The difference in point

\footnotetext{
$I_{\text {Table XVIII., p. } 77 .}$
} 
standings in the three groups were wide enough to bear statistical significance, and the conclusion may be drawn, therefore, that the criteria adopted by the committee were valid ones, which drew for the junior year accurate lines of distinction for scholarship groups.

TABLE XVIII.

SCHOLASTIC STATUS OF THREE GROUPS OF JUNIORS DISTINGUISHED BY THE CRITERIA ADOPTED BY THE CORMITTEE ON SENIOR COLLEGE ADMISSIONS

\begin{tabular}{|c|c|c|c|c|c|c|}
\hline \multirow[t]{2}{*}{$\begin{array}{l}\text { Standards } \\
\text { of } \\
\text { Work }\end{array}$} & \multicolumn{2}{|c|}{$\begin{array}{l}\text { First Group } \\
\text { Admitted } \\
\text { Uncondi- } \\
\text { tionally } \\
\text { Semester }\end{array}$} & \multicolumn{2}{|c|}{$\begin{array}{l}\text { Second Group } \\
\text { Admitted } \\
\text { Provisionally }\end{array}$} & \multicolumn{2}{|c|}{$\begin{array}{l}\text { Third Group } \\
\text { Not Admitted } \\
\text { General } \\
\text { Curriculum } \\
\end{array}$} \\
\hline & & & First & $\begin{array}{l}\text { Ster } \\
\text { Second }\end{array}$ & \begin{tabular}{|l|} 
Seme \\
First
\end{tabular} & $\begin{array}{l}\text { iter } \\
\text { Second }\end{array}$ \\
\hline $\begin{array}{l}\text { Average Number of } \\
\text { Hours Carried per } \\
\text { Person }\end{array}$ & 15.0 & 15.3 & 14.6 & 14.5 & 13.5 & 13.1 \\
\hline $\begin{array}{l}\text { Total Point } \\
\text { Standing }\end{array}$ & 1.7 & 1.6 & 1.3 & 1.1 & .75 & .94 \\
\hline $\begin{array}{l}\text { Per Cent of Hours } \\
\text { Failed }\end{array}$ & 4.2 & 3.3 & 1.9 & 1.6 & 9.9 & 5.4 \\
\hline $\begin{array}{l}\text { Per Cent of Hours } \\
\text { at } 300-400 \text { Levels }\end{array}$ & 65.7 & 75.2 & 65.0 & 66.9 & 21.8 & 40.2 \\
\hline
\end{tabular}

Note:- Average peychological score of the 1933-34 group equivalent to the 72nd percentile national. Average psychological score of the 1934-35 group equivalent to the 78 th national percentile. 
f. What questions arise out of applying selective methods?

After the general conclusion has been drawn, namely, that the Committeo did select wisely its scholarship groups, several other real or impressionistic problems are presented In the above data.

1. By reference to Table XVIII ${ }^{l}$ it may be seen that the first group made a higher average than the second, but that they falled more hours. Two explanations are suggested. One is that the first group probably includes more of the bright, erratic students who are more prone to allow themselves to stray into an occasional failure than the more consistent middle group. The second explanation is that the second group may have believed themselves to be on trial, as they were, and for that reason felt that they could not afford any failures. Elther one of these explanations is clearly a legitimate one and, if applied, yields no discredit to the Committeo's methods.

2. A second major consideration is forced by the difference in the per cent of hours at Senior College level between the first and second groups, each of which had a similar privilege of carrying full Senior College work. The first group, it is assumed, proceeded normally. The second group, however, held back on Senior College work, possibly so that they might maintain 1.00 averages, which is stipulated

$1_{\text {Table XVIII., p. } 77 .}$ 
by the Committee in a number of cases. This clinging to the Junior College courses was more noticeable in the second semester. It was in the second semester that the point standing of the group was a bare 1.09. If these students had not carried Junior College courses, presumably, the easier courses, would they have mairtained their 1.00 standIng? If not, then it is possible that the Committee may not have set its standards quite high enough to protect fully the scholastic standing of the group. On the other hand, and quite contrary to the foregoing conclusion, it should be noted that when this group held to Junior College subjects its point standing decreased and similarly that when the third group was allowed to take Senior College work of special interest to them their point standings increased. These are just faint Indications or suggestions that the student may really be better off in Senior College courses than in many of the Junior College subjects. What differences there are, if any, the student now seems able to bridge through the medium of his interest.

3. A third point of interest is the increase in Senior College hours for the lowest, third group in the second semester. This increase suggests that Junior College courses are exhausted after a fifth semester, or that the faculty felt that the students performed well enough in the first semester to substantiate opening more courses to them in the second semester. A point here, already noted above, is 
that the scholastic standing of the group improved simultaneously with their assuming more Senior College work.

4. A fourth point for which the sophomore tests were planned was to fulfill the responsibility of guidance. The tests afforded both faculty adviser and student a check upon his preparation for entrance upon Senior College studies. That this purpose was well fulfilled is demonstrated in the fact that from 162 sophomores tested in 1934 only sixteen selected a major in a fleld in which their attainment was below the norm set by 13,000 sophomores participating in the 1934 program. These sixteen students did not demonstrate superior achievement in any area.

5. A fifth point, closely related to the one just mentioned, indicates that 40 per cent of students, while choosIng majors in flelds in which they compared favorably in the national results, as stated above, did not choose these majors in the field of their own highest attainment. While social sqiences and natural sciences retained about 75 per cent of their best students, humanties retained but 50 per cent, ooclal sciences gaining from the sacrifices both in humanities and in natural sciences.

The number of students entering each situation are given in Table XIX. I

g. Did content become more difficult?

With the increased aptitude and background of the

$I_{\text {Table XIX., p. } 81 .}$ 
TABLE XIX.

RELATION BETWEEN ACHIEVEMENT IN THE NATIONAL SOPHOMORE TESTS AND THE AREA OF SELECTION OF THE MAJOR

\begin{tabular}{|l|c||c|c|c|}
\hline $\begin{array}{l}\text { Area of the Sophomore } \\
\text { Tests in Which Out- } \\
\text { standing Achievement } \\
\text { Was Demonstrated }\end{array}$ & $\begin{array}{r}\text { Division in the College } \\
\text { of Major Selection }\end{array}$ \\
\hline & $\begin{array}{l}\text { Number of } \\
\text { Students }\end{array}$ & Humanities & $\begin{array}{l}\text { Social } \\
\text { Sciences }\end{array}$ & $\begin{array}{l}\text { Natural } \\
\text { Sciences }\end{array}$ \\
\hline Humanities & 49 & 23 & 15 & 11 \\
\hline Social Sciences & 38 & 6 & 28 & 4 \\
\hline Natural Sciences & 75 & 3 & 20 & 52 \\
\hline Potal & 162 & 32 & 63 & 67 \\
\hline
\end{tabular}

Read: Forty-nine students of 162 demonstrated their most outstanding achievement in the humanities section of the test. Of the 49,23 chose majors in humanities, 15 in social sciences and 11 in natural sciences.

juniors now entering the Senior College, as assured by these stricter measures of fitness recently adopted, there was a sudden tendency either to make the content of the courses more difficult or to raise the grading standards or both. It has already been demonstrated that Senior College students recelved the same grades for a higher level of a chievement. When a group of $z 5$ of the highest standing students in the 
1934 Junior Class ${ }^{1}$ were paired with 25 students in the 1933 class, of the same sex, who had identical psychological scores, ${ }^{2}$ they were found to be 1.59 and 1.81 , respectively. This difference is especially significant in view of the fact that only the high group was considered, a group of particularly bright students who, if they were meeting conditions they could control would make the proper adaptations much more rapidiy than just any group of students. This evidence lends serlous weight, therefore, to the first hypothesis, that content was more difficult or standards of grading more rigid, without revealing which of the two was actualiy operative.

\section{h. What issues arose?}

(1) Because it has been considered inconsistent with objectives of the College to exclude any prospective students as long as physical equipment and staff can meet the demands of an unselected body, it is mandatory that more sympathetic consideration be given to provisions for this particular group. The task is somewhat simplified by the fact that from the beginning, the group who will be assured candidates for the low, third junior group can be determined. These are students who fail to reach the twentyfifth percentile on the psychological examination. It is also known for certain the one group of students who will

In determining the junior class that preceded this one, all students who had 60 hours of credit in June 1933 were called juniors, regardless of whether they were in good or poor scholastic standing.

2 The median psychological score for last year's juniors was equal to the 78th national percentile; for the previous class, the 72nd percentile. 
be included among those who will in the present course of things come up before the Executive Committee as cases for disciplinary action in the matter of scholarship. They will be all of those students in an entering freshman class who fall in the lowest quarter of both norms that we have set up for psychological and reading tests. In a class of 300 there were 60 students who "falled" both these tests, and there was not a single case, after two years, who had not had to have some action taken in the matter of scholarship.

(2) Another point which arises from all of the above is the question of the standardization of our standards. Evidently without our noting it we have at the junior year level, at least, undergone a serious upheavel in our grading system in one year's period. This change was not planned, and it is very doubtful whether it was not of irregular disposition. Some agreement on Senior College standards in requirements for written work, kinds of tests, quality of recitation and discussion groups, and the like must be reached. Not only must there be a good degree of agreement on these points, but there should also be considerable clarification in the matter of just how they shall differ from similar standards in the Junior College.

1. What was the effect on the major?

Losses in Major Departments. The changes in the curriculum in both offerings and takings have naturally affected 
the number of majors. Accentuating the decrease in the number of humanities registrations is the loss of Engl ish majors, the total of 21 in 1930 having dropped to 8 in 1934. The decrease in the education majors, the total of 25 in 1930 having dropped to 7 , is due to the elimination of the B.S. In Education degree and also to the reduction in credit allowed for Normal School work. The loss of majors in the department of history and political sciences is in contrast to the increased enrollment generally in these departments. It seems that, like the humanities division, the department of history and political sciences is also a supplementary department, serving other departments. The chief reason for the loss of majors in the home economics department is doubtful, although it might be attributed to the difficulties which home economics women encounter with the sophomore comprehensive examinations.

The Total Distribution of All Majors. The gains for majors in departments (not reporting losses) is not outstanding in any single instance. The departments drawing the most mejors in 1934-35 were chemistry, biology, and economics. About an equal drawing appeared in the departments of English, education, history and political sciences, and sociology.

The numbers of majors is reported by years in Table $x .^{1}$

$1_{\text {Table XX., p. } 85 .}$ 
TABLE XX.

THE NUMBER OF MAJORS BY DEPARTMENT AND YEARS $1930-1935$

\begin{tabular}{|l|r|r|r|r|r|r|}
\hline & 1930 & 1931 & 1932 & 1933 & 1934 & 1935 \\
\hline & & & & & & \\
Ancient Languages & 2 & 1 & 1 & 0 & 1 & 0 \\
\hline Biology & 13 & 3 & 7 & 4 & 4 & 10 \\
\hline Chemistry & 12 & 10 & 13 & 15 & 12 & 13 \\
\hline English & 21 & 18 & 20 & 22 & 15 & 8 \\
\hline Economics & 6 & 4 & 6 & 7 & 4 & 10 \\
\hline Education & 26 & 12 & 10 & 5 & 7 & 7 \\
\hline German & 0 & 2 & 6 & 4 & 2 & 2 \\
\hline History and & 14 & 7 & 10 & 11 & 6 & 7 \\
Political Sciences & 10 & 2 & 6 & 4 & 2 & 2 \\
\hline Home Economics & 2 & 6 & 8 & 2 & 2 & 4 \\
\hline Mathematics & 0 & 1 & 1 & 3 & 2 & 1 \\
\hline Music & 1 & 3 & 4 & 1 & 3 & 3 \\
\hline $\begin{array}{l}\text { Philosophy and } \\
\text { Psychology }\end{array}$ & 4 & 9 & 8 & 4 & 9 & 4 \\
\hline Romance Languages & 5 & 6 & 4 & 7 & 3 & 6 \\
\hline Sociology & 0 & 0 & 0 & 0 & 0 & 1 \\
\hline Physics & & & & \\
\hline
\end{tabular}

The Quality Point Standings of the Major. A study of the comparative quality point standings of single majors over the period under consideration indicates results as they are reported in Figure $2 .^{1}$ The variations among the Individuals within any major were so great and al so the number of cases so small, that a report of averages prima facie for any single major would be absolutely untrue. The one point that might be made here is that the variability among the individuals in a single major group was as great

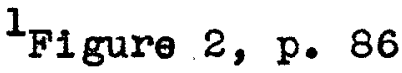


THE QULITY POINT STANDINGS OF SINGLE WAJORS CONPARED

FIRST SEMESTER OF 1930-3I and 1934-35

Scale

Quality Point

Standing

3.00

2.5

2.0

1.5

1.

0

$-. .5$

-1 :

$-1.5$

$-2.0$

$-2.5$

$-3.0$

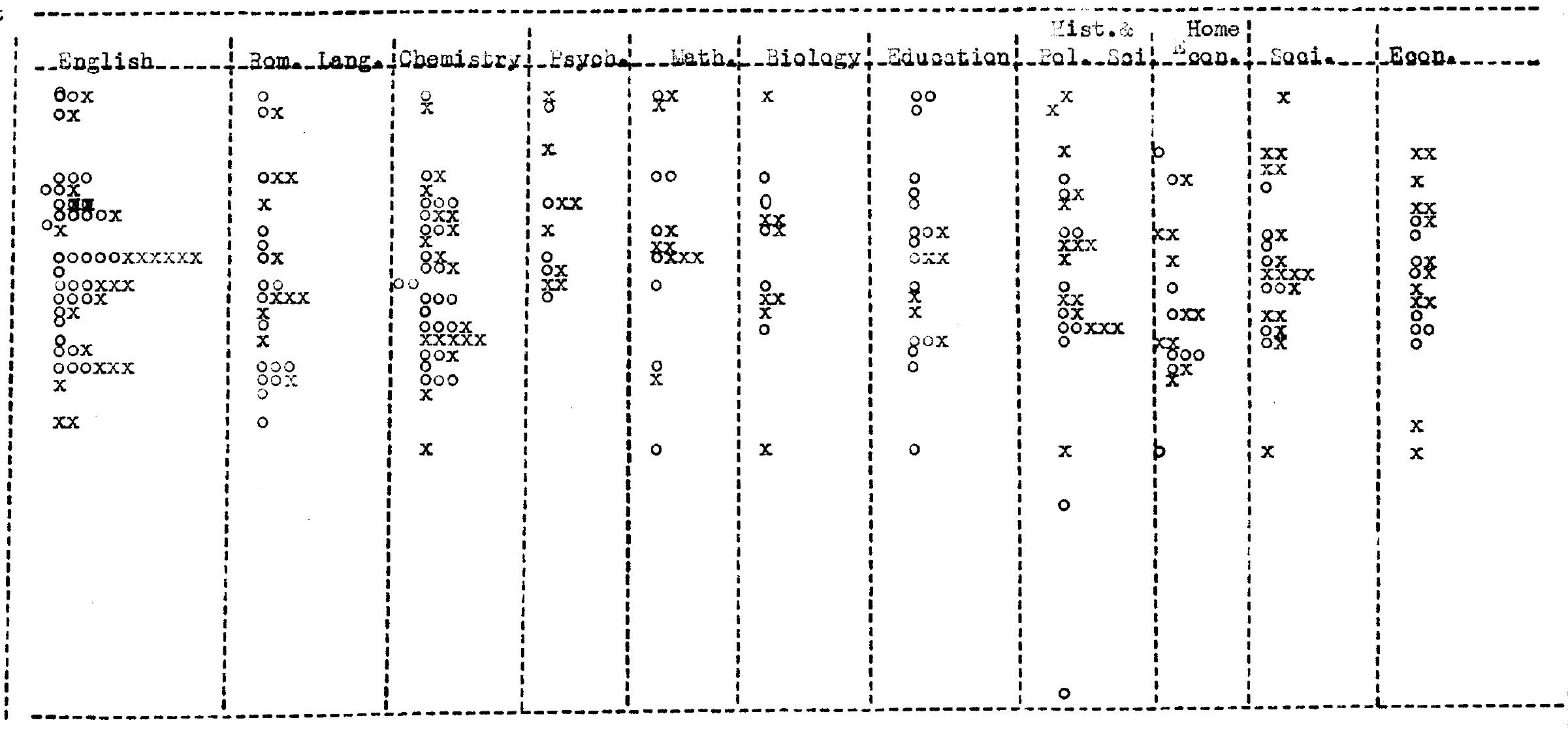

Ledgend: 0 . The point standing of one major in 1930-31

$x$ The point standing of one major in 1934-35

Read: In 1930-31 there were five majors in English with quality point standings of 2.0 wile in 1934-35

there were six majors in English with quality point standings of 2.0. These numbers inolude both juniors and seniors. 
in 1934-35 as in 1930-31, which is an indication that departments did not select their majors, at least on the basis of point standings, and from this second fact it follows -- quality point standing was not a prerequisite to entrance upon any major.

\section{Summary}

While the main body of aims for the Senior College remained the same in the bulk of offerings, new objectives were met, the trends being towards provision for the superior, vocational education, and integration of the fields of knowledge. The humanities division during the period lost rapidly its registration to the social sciences division, although there is no indication that this was due to a richer program of offerings. Rather, it seems better to attribute it to the trends of the times. Efforts to compare standards of work by changes in quality point standing are useless, since grading is shown to be relative to the group in both periods. The methods of making Senior College admissions seem to draw definite lines of distinction among the groups affected. The results from the sophomore comprehensive examinations indicate that the majority of students choose to proceed in fields in which they are competent, al though two-rifths do not proceed in the fields in which they demonstrate their best achievement. From this latter occurrence 
the humanities division loses most, while social sciences division gains most. On the whole the Senior College, through its offerings and general administration, seems to have held to its new purposes, has made revolutionary adjustments consistent with them, and has achieved a level of performance not heretofore equalled in this college. 
Chapter IV. THE EVALUATION OF ACHIEVEMAENT

A. Introduction. No program of reorganization, no matter how vital, can be well evaluated unless special provisions are made for objective measurement of the end results. Fortunately the faculty of the College has always been ready to adopt such measurements. By means of this cobperation and through the foresight of those directing the program, a rather thorough system of evaluation has been pursued.

The concept of evaluation of achievement as treated in this chapter will have two aspects: (1) that which denotes the personal efforts of the faculty to measure the achievement of individual students; and (2) that which indicates the efforts of the faculty to measure the program as a whole, to evaluate the ond results of reorganization.

B. Measuring the Achievement of Individuals.

Surely, no single college could have made greater effort to replace the old-type examination with the newtype objective test. In 1930-31 there was only one department, the department of psychology, which was making use of the objective test for the evaluation of individual achievement. In 1934-35 there was not a single department in the College which had not used at some time during the year a form of objective examination. Many departments 
used them to the exclusion of all others. There was introduced into the College in 1933 a file of test items for use in building tests for the survey subjects. This file was built up during the year and arrangement made to augment it constantly with the best test items drawn from the usual six weeks' and final examinations in the survey courses. Selection of the items was made after analysis of their discriminatory value and general difficulties.

A second indication of the use of the objective examination is evidenced in the growth of the mimeographing department of the College, which has had to increase its mimeographing service approximately 100 per cent in the past three years, due entirely to the more widespread use of the objective examination. The use of the objective examination was made possible partly through the granting of clerical assistance in the grading of such examinations. Tests for all the large classes were graded by clerks in the Research Office. By granting such aid, it was hoped to free the teacher for his duties in building such examinations, the construction of which is time-consuming.

It was thought, but no evidence is presented, that the system of providing definite periods throughout the year at which times the student was acquainted with his approximate status in the various courses he carried was one step in the evaluation of achievement which was a motivation factor for the student. 
To say that the new-type objective examination replaced the old-type essay examination is not in itself proof of its value. It wili be demonstrated, therefore, that the use of the objective examination made possible the awarding of grades that were more in keeping with the expected achievement of the student than was the case in the earlier period.

The first evidence is presented in the fact that the average point standings of freshmen in 1930 correlated with their aptitude scores on the American Council Psychological Examination only .28 \pm .04 while in 1934 this relationship had changed to $.50 \pm .02$. A second indication has been pointed out in a preceding chapter of this report, where it was demonstrated that the grades of seniors were more closely related to their achievement on a standard test in the later period, the relationship having changed from a correlation coefficient of .18 in 1930-31 to .70 in 1934-35. A third indication was obtained by comparing the adjustment of grades to intelligence levels in the two periods. From Table XXI ${ }^{1}$ it can be read that in 1934-35 the level of "A" grades and "B" grades was at a significantly higher level of intelligence than in the 1930-31 period and the demarcation between the " $D$ " and "F" level much more distinct than in the earlier period.

A fourth point of evidence lay in the fact that

$1_{\text {Table XXI., p.92. }}$ 
TABLE XXI.

THE ADJUSTMENT OF GRADES TO INTELLIGENCE LEVELS

A COMPARISON OF GRADES BY SUBJECTS AND INTELLIGENCE TEST PERCENTILES FOR FRESHMEN OF THE FIRST SEMESTERS OF 1930-31 AND 1934-35

\begin{tabular}{|c|c|c|c|c|c|c|c|c|c|}
\hline \multirow[t]{3}{*}{ Grado } & \multicolumn{9}{|c|}{$\begin{array}{c}\text { Percentiles on Psychological } \\
\text { Eraminations }\end{array}$} \\
\hline & \multicolumn{2}{|c|}{ Engl18h } & \multicolumn{2}{|c|}{ History } & \multicolumn{2}{|c|}{ Languages } & \multicolumn{2}{|c|}{ Sciences } & $\begin{array}{l}\text { ocial } \\
\text { cience }\end{array}$ \\
\hline & $\begin{array}{r}1930 \\
-31\end{array}$ & $\begin{array}{r}1934 \\
-35\end{array}$ & $\begin{array}{r}1930 \\
-31\end{array}$ & $\begin{array}{r}1934 \\
-35\end{array}$ & $\begin{array}{r}1930 \\
-31\end{array}$ & $\begin{array}{r}1934 \\
-35\end{array}$ & $\begin{array}{r}1930 \\
-31\end{array}$ & $\begin{array}{r}1934 \\
-35\end{array}$ & $\begin{array}{r}1934 \\
-35\end{array}$ \\
\hline $\mathbf{A}$ & (i) & (2) & $i \begin{array}{l}51 \\
2)\end{array}$ & $i 84$ & $\left(\begin{array}{l}74 \\
(2)\end{array}\right.$ & $i 96$ & $(58$ & i 79 & (1) \\
\hline B & $\begin{array}{r}69 \\
(12) \\
\end{array}$ & $\begin{array}{r}.74 \\
(12) \\
\end{array}$ & $\begin{array}{l}79 \\
(8) \\
\end{array}$ & $\begin{array}{r}.69 \\
(10) \\
\end{array}$ & $\begin{array}{r}64 \\
(17) \\
\end{array}$ & $\begin{array}{r}76 \\
(8) \\
\end{array}$ & $\begin{array}{r}51 \\
(13) \\
\end{array}$ & $\begin{array}{l}69 \\
(9) \\
\end{array}$ & $\begin{array}{l}79 \\
(6) \\
\end{array}$ \\
\hline C & $(20)$ & $\begin{array}{r}.66 \\
(27)\end{array}$ & $\begin{array}{l}.45 \\
(26) \\
\end{array}$ & $\begin{array}{l}69 \\
(20) \\
\end{array}$ & $\left(\begin{array}{l}51 \\
(14)\end{array}\right.$ & $\begin{array}{c}.65 \\
(20) \\
\end{array}$ & $\left(\dot{2}^{4} 4\right)$ & $(206)$ & $(287)$ \\
\hline D & $\left(\begin{array}{l}24 \\
(15) \\
\end{array}\right.$ & $(10)$ & $\begin{array}{r}.30 \\
(19) \\
\end{array}$ & $\begin{array}{r}.60 \\
(18) \\
\end{array}$ & $\begin{array}{l}45 \\
(8)\end{array}$ & $\begin{array}{r}.63 \\
(16) \\
\end{array}$ & $\begin{array}{r}.30 \\
(10)\end{array}$ & $(13)$ & $\begin{array}{r}58 \\
(15) \\
\end{array}$ \\
\hline $\mathrm{F}$ & $(i 24)$ & $\left(\begin{array}{l}33 \\
(5)\end{array}\right.$ & $i^{18}$ & $i^{25}$ & $(19)$ & $\left(\begin{array}{l}51 \\
7)\end{array}\right.$ & i 30 & (9) & $i^{26}$ \\
\hline
\end{tabular}

Read: The average percentile rank for " $A$ " grades in English in 1930-31 was 51; in 1934-35 it was 87. These data are compiled trom a 20 per cent sampling. The numbers in parentheses are round numbers.

failures in 1934-35 were concentrated in a smaller group than in 1930-31. In 1930-31 there were 14 per cent hours of failure among 35 per cent of the student body, while In 1934-35 there were 8 per cent hours of failures for only 25 per cent of the student body. 
The distribution of grades in the two periods as reported in the annual reports of the registrar are presented in Table XXII.

TABLE XXII.

DISTRIBUTION OF GRADES FOR THE COLLEGE ${ }^{1}$

\begin{tabular}{|l|r|r|r|r|r|r|r|}
\hline & A & B & C & D & F & I & WA \\
\hline $1930-1931$ & 10 & 24 & 32 & 17 & 12 & 1 & 3 \\
\hline $1934-1935$ & 10 & 27 & 39 & 14 & 8 & 2 & \\
\hline
\end{tabular}

C. Measuring the Program as a Whole

While the measurement of the Individual is important from the viewpoint of its effect upon the individual and the obligation of fairness in awarding grades, from the viewpolnt of reorganization it was really the program testing in the College that assumed the more important aspect of evaluation.

Program testing as it was administered in the College had several aspects: (1) Placement tests for freshmen for use in gauging the annual drawings of the College from the high school, for the purpose of providing a background for advising student loads and electives, for the purpose of 
placement in special sections or exemption from courses; (2) The National Sophomore Test Program, in which the College particpated each year beginning in 1932, for the purpose of checking upon the standards of the Junior College as a whole in comparison with other colleges, and for the purpose of advising the student upon choice of Senior College courses; (3) The College Achievement Test, ${ }^{1}$ which was given to graduating seniors every year beginning in 1931 for the purpose of checking upon the standards of the Senior College, particularly the major, and, in a sense, upon the College as a whole; (4) The occasional administration of standard tests in all courses where they have been avallable - physics, chemistry, biology, history, languages, and economics - have been further checks upon the standards of the College, as well as serving special purposes for the respective departments.

It $\mathbf{w 1 1}$ be the purpose of the remainder of this chapter to point out the results that have been obtained through the use of the program tests.

First, the use of the placement tests during the past several years gave conclusive proof that the type of student admitted to the College did not change to any significant degree during the period. ${ }^{2}$ The college drew a group of students quite representative of the normal college group in

${ }^{1}$ College Achlevement Test, published by Carnegie Foundation for the Advancement of Teaching. 1930.

$2_{\text {See Figure } 3, \text { p. } 96 .}$ 
the average college. The average aptitude is about the same and the extremes of the good and poor are approximately the same as the norms reported by Dr. L.L. Thurstone for the American Council Psychological Examination which is given throughout the nation.

The Thurstones report annualiy in the April number of the Educational Record the results for all colleges participating in the annual program. Results for the University of Loulsvilie are included in these reports. These results always approximated the average for all other participating colleges. The median quartiles for the College each year on this test and the equivalent percentiles are reported in Figure 3.1 Achievement, on other than the peychological examination, while varying both upward and downward from the norms, maintained its position relatively for the local groups during the period. These standings are depicted as graphic representations in Figures $4^{2}, 5,3$ and 6.4 From these figures it can be read that on the Kentucky Classification, Cobperative English, and Nelson Denny Reading Tests, the College freshmen maintained approximately the same standing year after year. The averages for previous years are compared with averages for 1934-35.

From the records as depicted in the foregoing figures the faculty has been able to establish the fact that the 
COLLEGE STANDING BY MEDIANS AND QUARTILES

FOR ENTERING FRESHMEN OF SEPTEMBER

$1930-1931-1932-1933-1934$

AMERICAN COUNCIL PSYCHOLOGICAL EXAMINATION

$\begin{array}{lllll}\text { Sept. } & \text { Sept. } & \text { Sept. } & \text { Sept. } & \text { Sept. } \\ 1930 & 1931 & 1932 & 1933 & 1934\end{array}$

National

Percent1le

Scalo

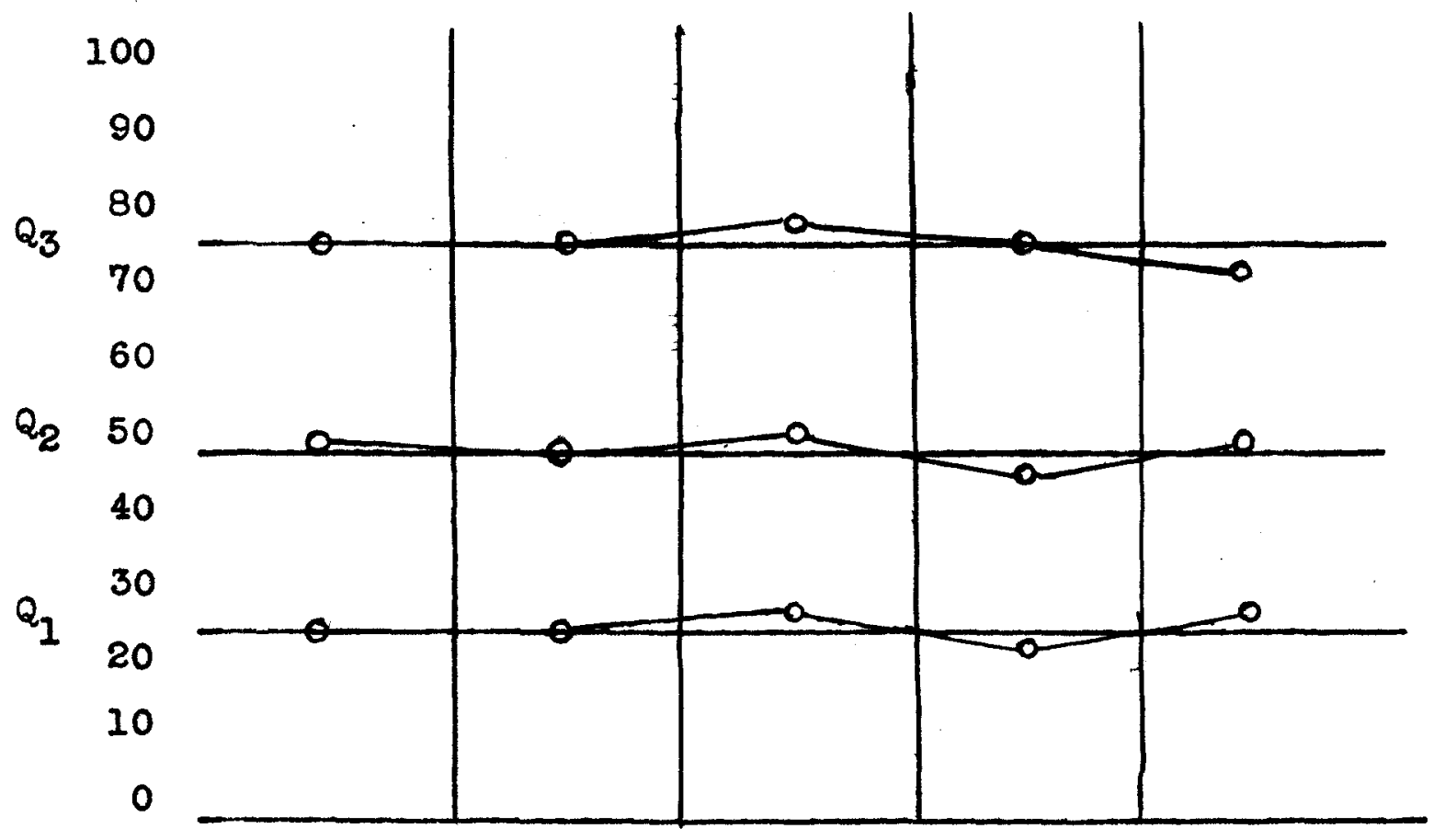

Read: The median and upper and lower quartile points for College students are represented by olrcles. These points are almost identical to the same points for the normetive basis, represented by straight horizontal lines.

Figure 3 
QUARTIIE POTNTS FOR UOFL FRESEDEN

ON

COOPERATIVE ENGLISH TEST

COMPARED WITH NATIONAL NORMS

\section{Percentile}

Scale

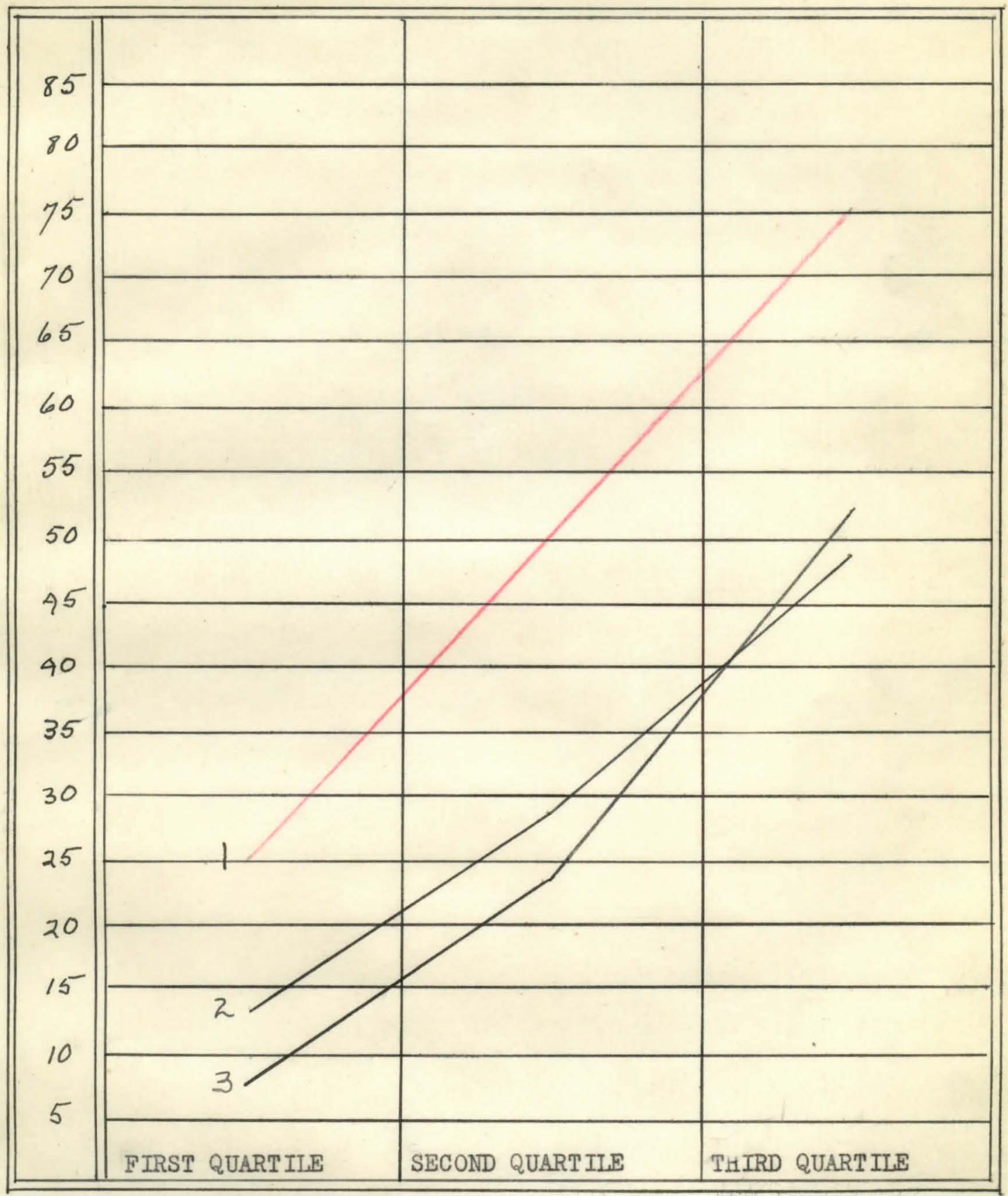

LEGEND

1. NATIONAL FRESHMEN

2. ENTERING FRESHIEN, '34

3. ENTERING FRESHIEN, SEPT. '3 2 - FEB. '34 
QUARTILE POINTS FOR UOPL FRESHMEN

ON

KENTUCKY CLASS IFICATION TEST

COMPARED WITH NORMS FOR STATE COLIEGES

Percentile

Scale

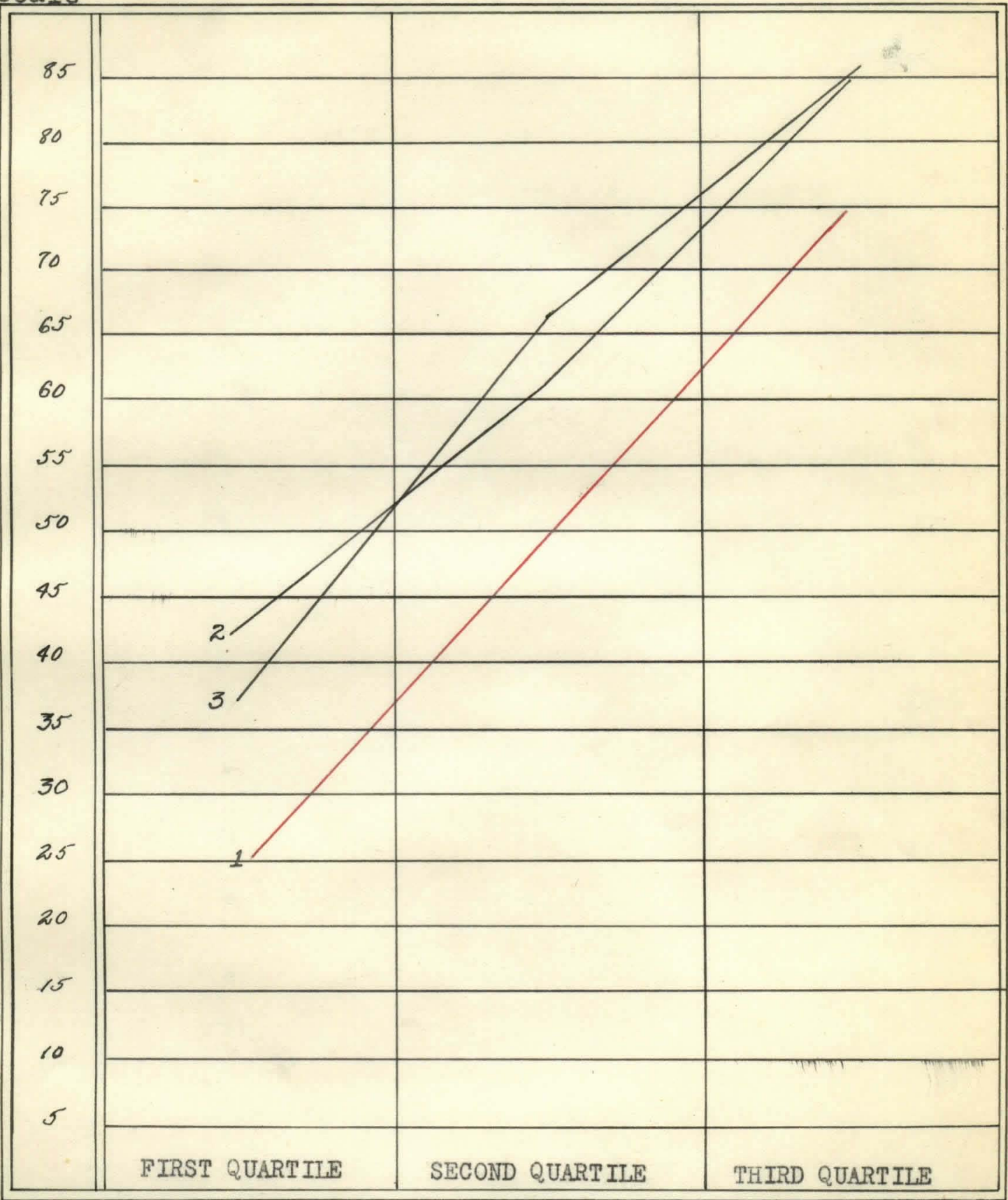

IEGEND

1. COLLEGE FRESHMEN, 7 KENTUCKY COLLEGES

2. ENTERING FRESHIEN, UofL' 34

3. ENTER ING FRESHMEN, FORMER YEARS 
QUARTILE POINTS FOR UOFL FRESHDEN

ON

NELSON DENNY READTNG TEST

COMPARED WITH NATIONAL NORMS

Percentile

Scale

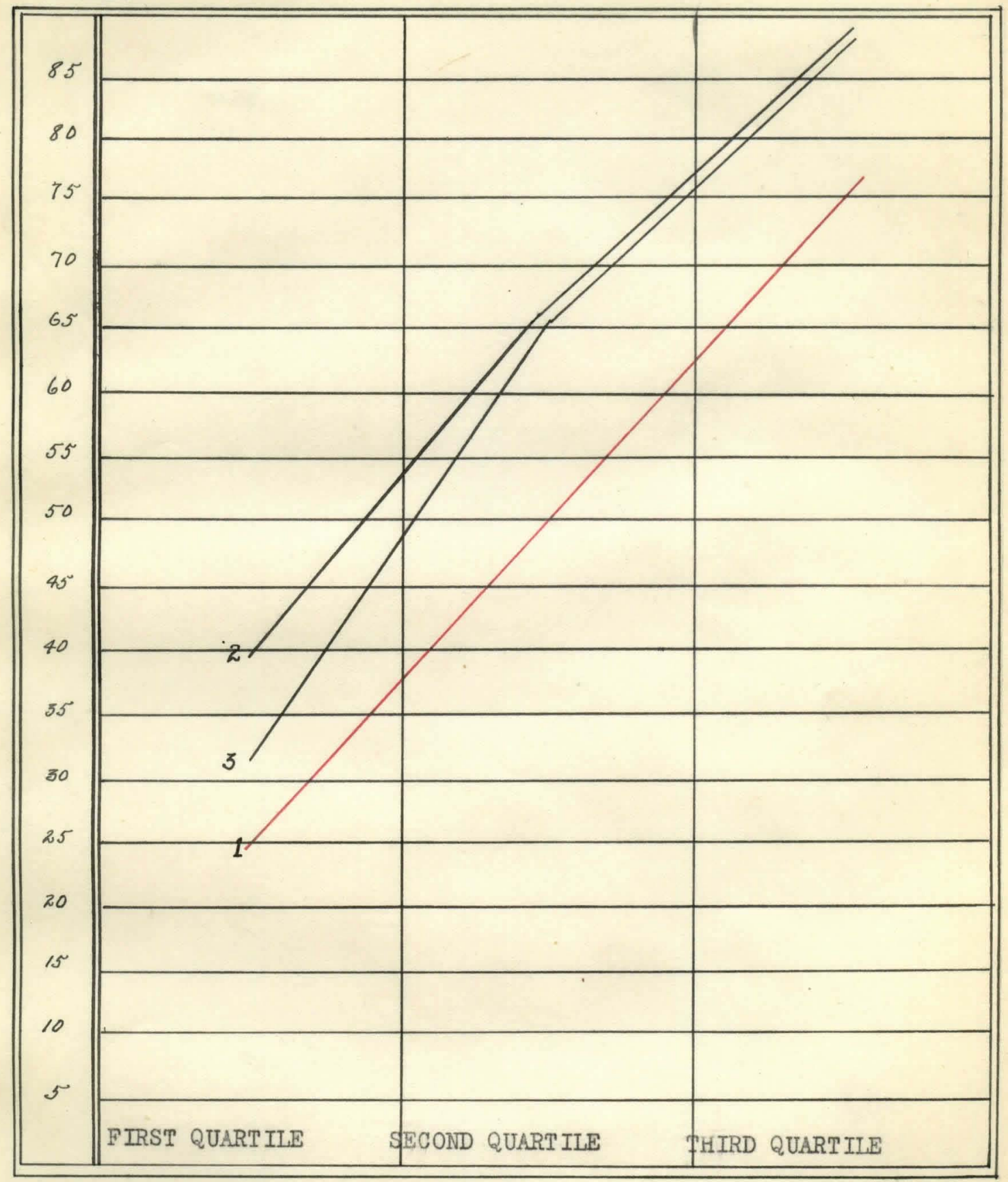

\section{LEGEND}

1. NATIONAL FRESHIEN NORM

2. ENTERING FRESHIEN $: 34$

3. ENTER ING FRESHIEN, FORMER YEARS 
Figure 7

ACHI EVEMENT OF SOPHOMORE CLASS OVER A FOUR YEAR PERIOD YEARLY PLACEMENT OF MEDIANS ON NATIONAL SOPHOMORE TESTS $1932-1935$

National Scale of Percentiles for Six Thousand Sophpmores Tested in May 1935

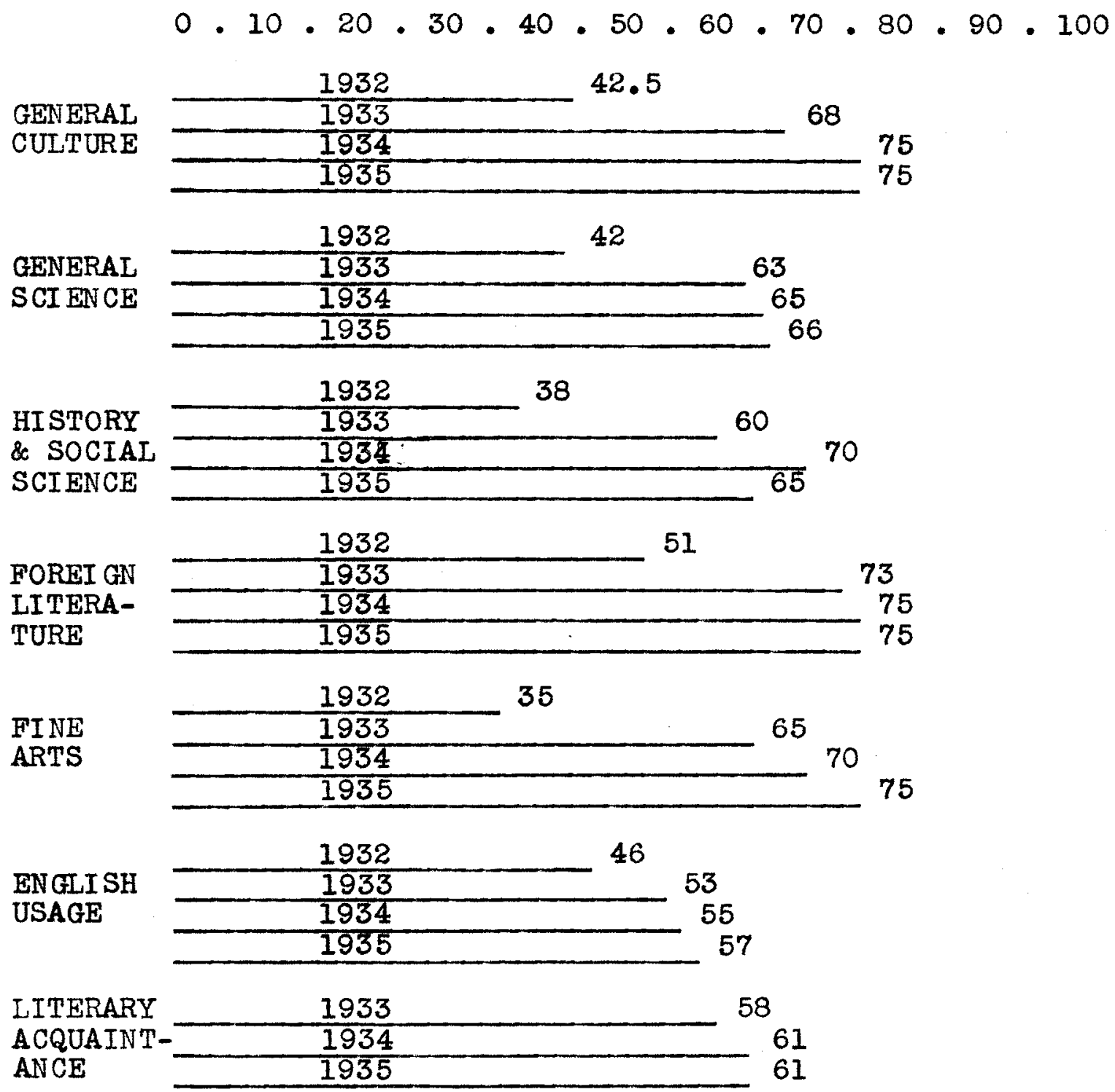

Read: This figure shows the gradual rise in median score by years. The greatest single gain between years is between 1932 and 1933. At the present time all work measured is above the national median, which is 50. In the cases of General Culture, Foreign Literature and Fine Arts our median scores are equivalent to the national upper quartile score. 
NATIONAL COLLEGE SOPHOMORE TEST

PLACEMENT OF LOCAL MEANS OF SOPHOMORE CLASSES

OF

$1932-1933-1934-1935$

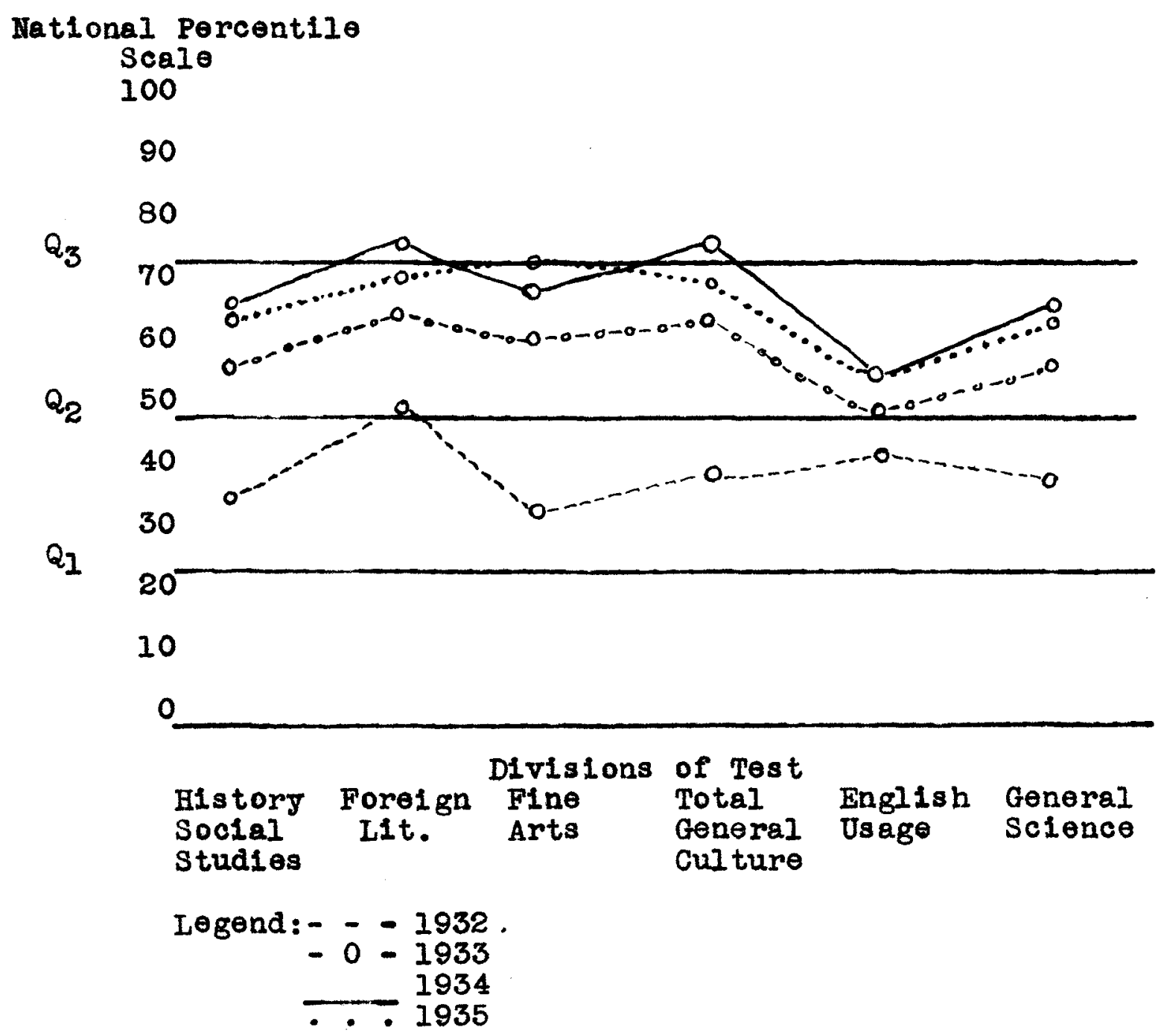

FIgure 8 
ACHIEVEMENT OF GRADUATING SENIORS

YEARUY PLACEMENT OF MEDIANS AND QUARTILES ON THE

PENNSYLVANIA COLLEGE ACHIEVEMENT TEST:

Scale for $1931-1935$

Pa. Horms

100 -

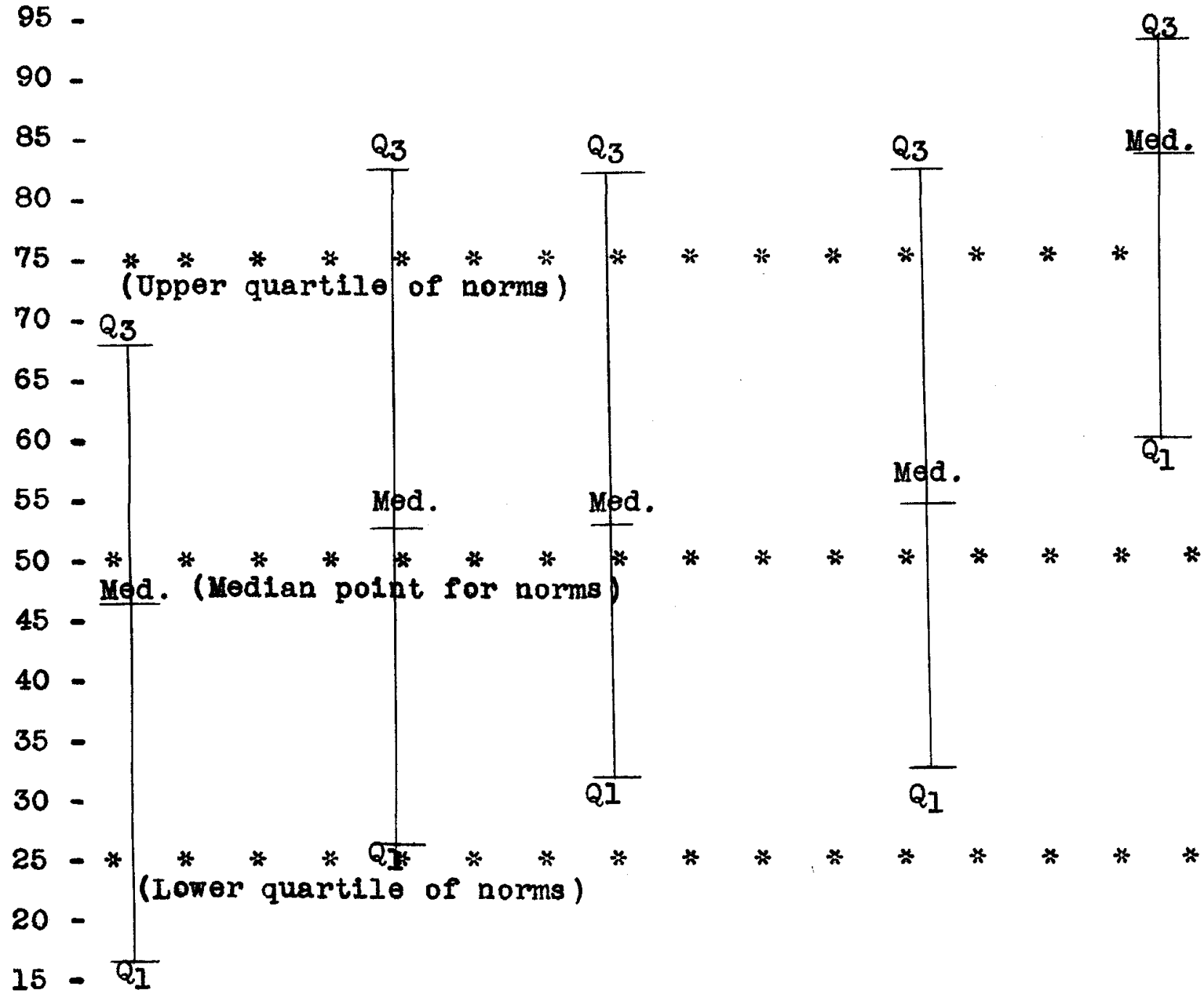

0

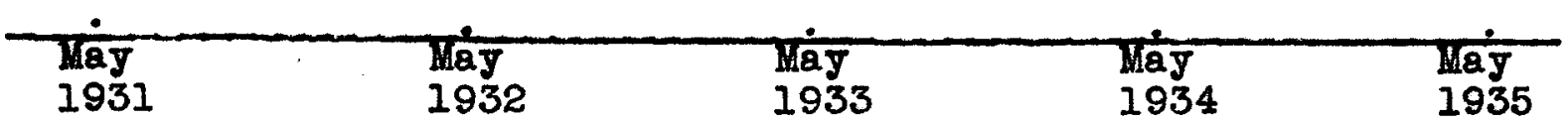

Read: To correspond to the Pennsylvania norms it would be necessary for the horizontal lines to coincide with the starred lines. In 1931 our midale and quartile scores rere considerably below the norms. A gradual improvement, particulariy at the 10 quartilo can be noted for 1932, 1933, 1934 and 1935 . 
CHANGES IN PLACEMENT OF MEDIANS

ON

COLLEGE ACHIEVEMENT TESTS

Betreen 1931 and 1934

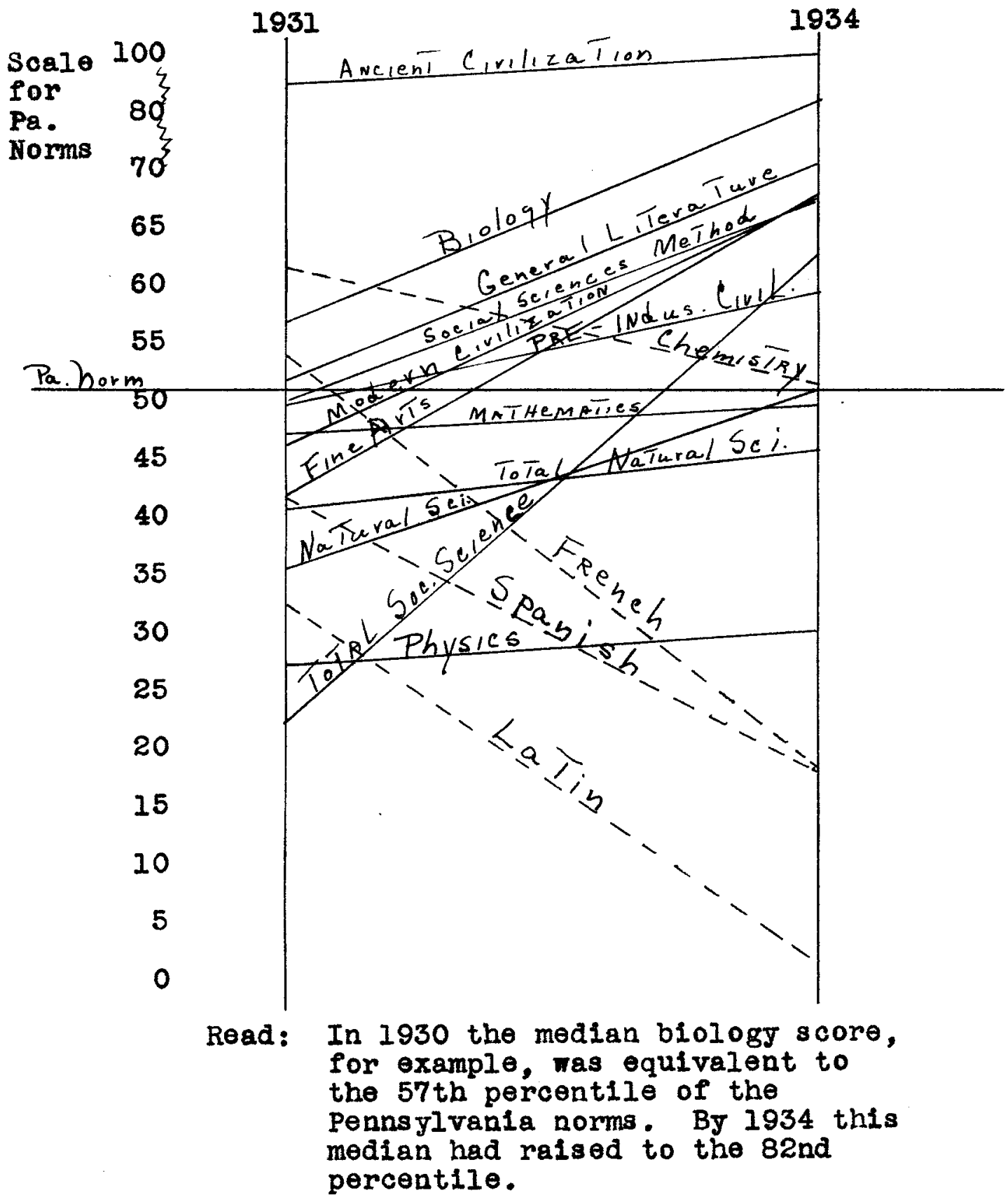

Figure 10 
change in the student achievement came from factors operative within the College rather than from changes in the type of student matriculating in the College.

Second, the participation in the National Sophomore

Test Program yielded results which were definitely reassuring to those most concerned with the end results to be obtained in the new program for the Junior College. It has been pointed out that the chief changes in the Junior College were the elimination of Senior College students from its elective work and the substitution of the survey courses and the survey examinations to replace former requirements of the traditional nature. Not only was the faculty able to see the sharp up-grade in achlevement dating from the year in which the changes were instituted, but it had the assurance that achievement in the College was much above the par for sophomores throughout the nation. Such results may be obtained from the Figures $7^{1}$ and $8^{2}$.

Third, the use of the Collece Achievement Test also yielded results which have been most reassuring to the faculty interested in Senfor College Achlevement. Figures $9^{3}$ and $10^{4}$ show in the last year reported, that is for the testing of seniors of 1935, a phenomenal increase in achievement when there was graduated the first class that had shared in all of the new requirements of reorganization, namely: Junior College survey courses, elimination of Junior College 
electives at Senior College level, more accurate measures of achievement, major and divisional comprehensives, major and divisional co-ordinating courses, and various other features of the re-organized College. The results for each year were compared with the results obtalned for approximately 4,000 seniors in the State of Pennsylvania in 1930-31. The levels attained by the respective classes of 1931, 1932, 1933, 1934, and 1935 are shown in Figure 9.1

Checks on individual areas of knowledge have also been obtained through the use of the College Achievement Test. The comparative standings in the separate areas for 1931 and 1935 are shown in Figure 10.2 This figure reveals that while there was some gain for all fields, except the languages, the gain in the social sciences was the greatest. The facts revealed by Figure $10^{2}$ must be interpreted with a great deal of care. Their significance is not obviously apparent. Certainly they should not be accepted as criticisms of any department or division. It is my conclusion that they must be interpreted as end results of reorganization rather than as variations in quality of instruction from department to department. With greater emphasis upon the social sciences, including the addition of new courses, it is natural that the greatest in be shown here. It is possible that other departments have suffered their greatest loss in students due to the 
increased emphasis here and the resulting interest among the students in the newer courses. In the case of the languages it will have to be decided whether the new language requirement was the cause of the loss, or whether It was occasioned by the drain of students from the language departments into the other departments.

\section{Summary}

The objective type of measurement has predominated in reorganization. The faculty has given close attention to the improvement of its own tests as well as to the selection of suitable standardized instruments. The results are most apparent in a practice of grading which has become more closely alligned with expected student a chlevement. The faculty has been able to watch pridefully the steady gain in achievement each year at both the Junior College and Senior College levels, although it had evidence that entering classes have remained practically the same in ability level. Individual faculty members have had through the use of standard tests the satisfaction of learning that their own courses meet approved national standards. The work in tests has contributed a body of test items for future use that will mean better tests constantly with less effort. 
Chapter V. SENIORS' RATING OF THE COLLEGE

A. Introduction. Since the College fostered innovations in teaching procedures and details, as well as revised curriculum offerings, it seemed appropriate to inquire of the student body their opinions of all these changes, which were promoted solely for them. Pursuant to this thought, the opinions of graduating seniors were solicited in June, 1935, the solicitation netting 64 of a possible 88 voluntary, anonymous replies. The inquiry was in the form of a questionnalre, and the replies, which were tabulated or summarized, are included in this report because the opinions of graduating seniors who have had direct experience with the many phases of education which the College endeavors to promote should be significant.

The questionnaire is not a perfect instrument of measurement, but its unreliability can be counteracted in some respects by the sincerity of those answering it, and in this case it was our observation that answers were painstakingly weighed in most instances.

The Curriculum. According to the seniors the colrdinating major course was valuable in theory ( 100 per cent), but many and varied suggestions were of fered for improving the cobrdinating course of each major. These suggestions embodied demands for 'moderm aspects,' 'wider and more varied readings,' 'the practical sides of our studies,' 'outside lecturers,' 
'exemptions for those who can pass the tests at the beginning of the year,' 'a syllabus,' 'broader outlines,' 'a year-course instead of a semester,' etc. The divisional requirement of Senior College work in the field of the major was favored by 73 per cent of seniors. Two-thirds of the class would have taken advantage of a typing carse, had it been offered. Sixty-three per cent of the group wished that the College had offered a course in correct study methods that they could have taken as freshmen. Opinions differed on the best time for offering such a course. Fifty-two per cent thought 'during the first two weeks in College,' 45 per cent 'after the student has had a chance to realize his need,' and none 'during the summer before entrance.' Eighty-nine per cent thought that it should be given only for those who seemed to be assured college failures at the time of entrance. When the seniors were asked to check from a list of ten the four points that should be stressed most in such a course those points receiving the greatest vote were: note-taking 79 per cent; increasing reading comprehension 50 per cent; notes for studying for examinations 54 per cent; and library reference training 45 per cent. Writing up laboratory manuals and outlining opposing viewpoints were each voted zero.

The most popular Junior College subject was general psychology, receiving the vote of 26 per cent of the group; humanities survey was second with 17 per cent of votes; the 
remainder of votes were scattered with less than 1 per cent for each of 47 subjects, which is a good indication that students meet their individual needs through all college offerings. It should be added in justice to other courses that the psychology and humanities preferences must have been somewhat tempered by the tact that the majors requiring them as prerequisites represented the largest major groups in the class and, therefore, increased the possibilities of a large vote.

Elghty per cent of the senfors were satisfied with the major that they had chosen. Thirty-nine per cent said that they would prepare themselves for different courses, if they had their college work to do over. The fields of social case work and medicine received the greatest increments from such proposed change. Twentyfour per cent expected to teach when they left the College, 26 per cent to practice medicine, 20 per cent 'to work.' Only 2 per cent were al ready 'practically sure' of receiving placement through the influence of friends or relatives. Teaching Procedures. Concerning teaching procedures in the College, 61 per cent of the group thought that teachers do too much lecturing in Senior College, at the expense of discussion groups; on the other hand only 36 per cent thought that there was too much lecturing done in the Junior College. The class was evenly divided on the question of too much supplementary reading both in 
Senior College and in Junior College. Only 15 per cent thought that there was not onough written work required In Senior College; 30 per cent thought there was not enough required in Junior College. When the question of substituting reading periods for the last two weeks' work preceding final examinations was raised, 59 per cent favored and 41 per cent disapproved. As long as students pass the examinations and fulfill the required work, 82 per cent agreed that class attendance was immaterial. Students on the Dean's honor roll should be granted special privileges according to 85 per cent of seniors. Suggestions for improving both curriculum and instruction in the Senior College were offered by practically everyone replying to the questionnaire.

Tests and Examinations. Fifty-seven per cent of the group thought the College gives too many tests. For determining Serior College admissions, 48 per cent of the group thought it justifiable to substitute a high grade on a standard test for fallure or low grade in a course. Seventyolght per cent favored 'grading on the curve' in large sections. Ninety-one per cent favored excusing seniors from final examinations, assuming that finals might be taken if desired. Eighty-four per cent said they studied differently for objective and essay tests, which agrees with findings of several investigators of this problem. Although 69 per cent thought that the essay examination required more hours of 
preparation, 62 per cent thought that the better results were obtained from the objective test.

Organizations. Among non-fraternity campus organizations the Blology Club was stated as most popular by 33 per cent of the graduates, the Players Club receiving 16 per cent of votes and the Mathematics and Chemistry clubs receiving 8 per cent of votes. Again, how much these choices were influenced by the number of majors concerned was not revealed in these figures. When asked what was the most promising organization, the Biology Club was again nominated by 37 per cent and the student Council by 30 per cent. It is significant here that other organizations were each mentioned by less than 1 per cent of the voters. Loyalty Among Studentsand Good Will in the Community. Whon students were asked what to do about improving loyalty on the campus, no consplcuously new 1 deas were given. Founders' Week was the most outstanding activity that promotes good will in the community, receiving 26 per cent of the votes; plays and concerts were next, receiving 24 per cent of votes; radio programs, the Kentucky Derby Festival float, and the Forum were each nominated by 5 per cent.

\section{Summary}

In sumarizing the results, it may said: that this class as a group was in sympathy with the reorganization 
of the Senior College but that they saw many places where improvements could be made; that they were non-committal on the question of how to build loyalty on the campus and good will in the community; that they desired that more vocational curricula had been part of their college's program of studies; and that half the class favored the testing programs upon which the College has placed so much stress while the other half disapproved. 
Chapter VI. FINAL SUMMARY OF MAJOR FINDINGS

1. The story of reorganization in the College has been a swiftly moving one, each year witnessing the introduction or acceptance of many new plans for the curriculum, for guidance, for campus life, and for an evaluation of the total program. All steps have been in the direction of what is commonly designated "the progressive college" program. Through analysis and experimentation the college strove to study its problems, the evidences of 1 ts efforts being demonstrated in the character of research undertaken.

2. In the revision of aims and objectives greatest change is apparent in the Senfor College organization where in the five-year period of consideration there has been an eighty per cent turnover in offerings. The changes in the Junior College have been centered in the introduction of five general survey courses and the requirement of sophomore comprehensives in these same areas, which have definitely affected the requirements in the Junior College program of studies. On the whole the majority of offerings of the college curricula are still of the traditionally academic type. The innovations introduced into the college offerings show decided trends towards a contemporary emphasis and towards the integration of knowledge.

3. Changes in aims and objectives and in course offerings have not been merely figurative but have been accompanied 
by a corresponding response from the student body, reflected in a decided shift in enrollments among the various departments and divisions. While the social sciences division has made no gain in the number of majors it has gained phenomenally in general registrations throughout its courses, an indication of its general popularity as an elective field. The gradual loss in the division of the humanities offers an unexpected contrast to the gain elsewhere.

4. Increase in student registrations in courses, unaccompanied by a relatively large increase in enrollment indicates that students carry heavier programs than in the earlier period, although electives are freer and more abundant.

5. Growth in the number of classes was brought about by the increase in the small Senfor College classes. With increased student loads, more classes and no change in the number of faculty, the faculty load has also increased.

6. In guidance the main trend has been towards the accumulation of student records, but this accumulation is still recognized as inadequate to the demands put upon it. Provisions for the superior student are again and again evidenced in College policies, the latest and most farreaching in results being the acceptance from the junior year of superior high school students who are permitted to enter upon a college program of studies.

7. Aside from the question of aims and objectives the 
Senior College has been most concerned with its admissions plan, which seems to be making the expected distinctions among students.

8. A program of evaluation employing nationally used comprehensive examinations as well as locally prepared ones demonstrates that a level of achievement has been reached in both Colleges that is not only beyond the normal but much beyond the expectation of the faculty for the Louisvilie group of students.

9. Not only has the College had the opinion of its faculty and the results of achievement tests in evaluation, but it has also given voice to student opinion in the matter. The results of a questionnaire issued to graduating seniors of June, 1935, indlcate the accordance of the student in reorganization. 
Chapter VII. SUGGESTIONS FOR FUTURE PROGRAM AND RESEARCH

It has been practically impossible for this writer to have worked over a body of materials pertaining to the reorganization of the College and not have arise out of the effort ideas for further refinements or expansions in the various areas of consideration. It is not in any spirit of destructive criticism that these suggestions are made or in any expectation of belief that they have not been voiced before by other persons interested in the welfare of this College.

To maintain the coherence of the thesis the suggestions for further research will be presented according to the original main outlines of the thesis, that is, in the areas of aims and objectives, individualization of the student, the Sentor College, and the evaluation of achievement. However, within the main body of the thesis there was no particular attention given to methods of instruction, because it was felt that changes in the methods of instruction had not been a very dominant note in the reorganization of the College. Anyone who becomes acquainted with the field of educational research will soon find that it is in this particular area, that least has boen done in higher education. It is not surprising, therefore, that the College in its reorganization also should have under-emphasized this important aspect in 
1ts program. Because methods are important, and because the writer wishes to point out some of the posstbilities for further improvement of the College, it becomes necessary to depart from the general outlines of the thesis, but only insofar as to add this one additional area, the improvement of instruction, which will be treated first.

\section{A. The Area of Improvement of Instruction}

If as much interest could be created in the college in the cause of methods as has been created for the causes of curriculum and evaluation, the college would indeed be an ultra-progressive institution. The program for the future will have to take into consideration, more than it has in the past, devices for improving instruction. This is a field which leaves much to the initiative and ingenuity of the individual instructor. The necessary background is, first of 211 , an administration sympathetic to originality in instruction; secondly, a great deal of time for the experimenting instructor; third, a keen faculty either trained in educational research or responsive to the training of a directing expert; and fourth, depending upon the nature of the experiments, helpful clerical assistance. While it is not advocated that every faculty member and every class in the College be involved in experimental work in instruction, it is advocated that several experimental 
set-ups be maintained and publicized at all times, that the results be reported and presented periodically to the entire faculty, and that the aims of such research be always directed to the best interests of the student. Means that have been taken in other institutions, which could be employed here, to stimulate the interest of faculties in researches in instruction have been: faculty seminars on the improvement of instruction, annual ratings of instruction by division heads, student seminars to voice student opinions of methods, external examiners, visiting experts, and financlal recognition for improved innovations.

At the moment there are several fields in the College open to experimentation. The entire question of administering independent study is one of the issues to be settled. There is some evidence that independent study has not been entirely successful. There is need for consideration of the costs of independent study, the administration of the plan, as well as the worthwhileness of the undertaking for the individual. How much of a teacher's time is consumed with independent study pupils? $\mathrm{H}_{\mathrm{O}} \mathrm{w}$ well prepared is the instructor to undertake the many subjects desired by students under this plan? How difficult is this work in comparison with ordinary college courses? What should be the manner of recruiting students for independent study, or is this recruiting necessary? What are the reasons accounting for the fact that students who have had independent study will not 
continue in 1 t?

A second field for investigation is in methods of approach employed in certain of the Junior College subjects that overlap or repeat high school work. It seems that many of the Junior College subjects would profit a great deal simply by a new approach. This is really as much a consideration from the curricular point of view as from the methods point of view. The rearrangement of subject matter and its presentation from new and interesting angles could do much to re-vitalize subject matter that, it is felt, must be repeated.

Another area for investigation that has arisen constantly in faculty discussions is the use of the test in promoting study. More might be done along the lines of discovering the comparative effects upon the student of the assignment of subjective and objective tests. Further, the part which the assigned topic for term paper or class discussion can fill in promoting learning and retention of learning remains an open question.

In its recent acceptance of students from the high school, and in their apparent success in the College, is raised the question of accoleration at all levels. It might easily happen that a student in his freshman year might make as much progress as the average sophomore student. Should not the College consider the acceleration of these students? The College would not be pioneering in 
undertaking such a step. It has been considered in other colleges, and its success at Buffalo is well known.

Likewise, the College must consider to what extent it can afford to contend with the retarded student. What is the cost of the retarded student to the College? How many cases exist throughout the enrollment? The College might follow such a plan as that recently inaugurated at Stephens College and settle for itself the question of whether or not the retarded student can ever reach the level of attainment necessary for successful completion of either Junior or Senior College offerings. If special provisions that involve expensive procedures are made for such students, then some consideration should be given to making a proper assessment on the student for the expense to the College in their behalf, and, more directly, to the taxpayer, and to the other students in the College who do proceed normally. If special work is to be offered to such students there immediately open up many questions concerning methods adapted to this particular retarded group.

The matter of awarding grades to students in their courses is looked upon as a great motivation factor by many, as a decided deterrent to semester organization by others. The determination of the degree of motivation might easily be determined by a controlled experiment which could consider the comparative effects of revealing and withholding grades. 
The recent purchase for the College of a moving picture machine and of several reels of film in science subjects will raise shortly many questions concerning its best uses, which experimentation only will be able to answer. The use of the motion plcture in higher education is so new that there has not yet been time to introduce Into the literature of education the results that have been obtained. Some of the questions that arise are: how often should a single film be shown? should the lecture precede or follow or accompany the showing? is there better retention if the students are led to expect a quiz? is retention better or poorer? is the motion picture adapted to all types of intelligence? are such handicaps any greater than those that take place in the ordinary classroom situation? how much relief is given to the teacher's difficulties in teaching, that is, is teaching easier or more difficult? can larger groups of students be taught by this method? what are available films for other than science subjects?

This College, as all other colleges, still has with it the perennial question of the efficiency of the large vs the small section. Perhaps more attention has been given to this phase of methods in higher education than to any other phase, but the evidence is still very contradictory and the question completely unsettled.

There remains open, too, the question of the best methods of promulgating student opinions and attitudes. 
With the increasing importance of the forum in public life, there seems to be a need for the type of training that will give the student leader opportunities to excel in this type of expression.

The areas suggested above for investigation are general. There are many more specific areas in connection with each field of subject matter that only the instructor can handle to any avail. I am thinking particularly of each of the new cobrdinating major subjects, of the divisional courses, of peculiar set-ups in biology and chemistry where preparation and aptitude vary so much, where there exist. plentiful material for investigation that should improve these offerings.

In summary, I would say that the principal need of the College at the moment is this need for a faculty consciousness of the role of method and a recognition of its effects upon student motivation and achievement.

B. The Area of Aims and Objectives - the Curriculum

It has been pointed out that the Junior College-Senior College division was an outstanding reorganizationalfeature. One of the closest checks which the College can pursue for the testing of this arrangment will be the follow-up upon student retention. As the ideals for the College become more and more ingrained, student retention at the end of the 
second and third semesters will continue to be greater. There is already a declded tendency in this direction, which, no doubt, will increase with the years.

It has been demonstrated that the College curriculum is still predominantly of the traditionally academic type. The College might take some means of determining whether it is the traditionally academic type of curriculum that is best suited to the higher education of this urbancentered society. The University draws the great majority of its students from the City. It is partly city-supported. But the College has as yet made no attempt, except through its division of adult education, to fit its curriculum definitely to the requirements of the City, although the University has in many ways taken advantage of other means at its command to serve the City. It is not suggested that the present Iiberal Arts curriculum is inadequate. How adequate or inadequate it is is not known. It is suggested rather that the Liberal Arts curriculum, for instance, might be better correlated with the cultural possessions of this city, that cognizance be taken of the contemporary culture emphases for this city which could be directly related to the present Iiberal Arts curriculum and that uses be made of these centers through a sort of laboratory technique in instruction. Secondly, it is suggested that surveys be made of other interesting civic possessions or activities which could be directly correlated with the 
classroom activities of the several departments. Such a survey might point out, for instance, the value of the Louisville Public Forum to a class in public speaking, the activities of the younger Democratic and Republican clubs to a class in political Parties, department store courtesies that might be extended to prospective student buyers in home economics, and the like. Third, it is suggested that a survey be made to determine the possibilities of apprenticeships for advanced students majoring in subjects that may bo immediately related in this society. The plan here is to establish for these students such opportunities as those provided at Antioch College. Fourth, the College might determine in what ways it may best serve the civic groups and simultaneously glean valuable course material for its students. In what particular work might a sociology student, for instance, engage which will also be a contribution to the society of this city? At the Western Reserve University of Cleveland, for instance, students have recently compiled the most comprehensive and valuable statistics on the economic and social status of the city of Cleveland that have ever been assembled there. The volume of statistica is a source of reference for many agencies. Fifth, is suggested the preparation of an entirely now set of courses to be offered for the General Curriculum and as electives to any Junior College student, 
in the science of human relations -- family, vocation, religion, and in other realms of social adjustments. What these courses should contain might partly be obtained through the experience of adult leaders in the community, through the opinion of recently graduated alumi, the experience of other educationists sharing the same outlook, and certainly through the voice of students themselves.

One means of keeping up-to-date in curriculum and of gleaning many helpful ideas is through a study of college catalogs and their descriptions of courses. Such a compilation was made during the last year for humanities survey. The instructor obtained an idea of what was being done in other colleges along his line of interest, some idea of how it was being done, and a mailing list of instructors in his field. Other such compilations might well be made for other instructors who have a particular subject matter or course outline problem.

Both the College and the College curriculum might profit by a good deal more publicity than they now receive. Presentation in print lends a definiteness which is in itself valuable, but publication also brings what is still more valuable to the instructor, the criticisms of colleagues in other colleges.

If the College could affort the advice of several extermal curriculum experts to review its present situation 
it would be well re-paid. And if the college could afford to send its instructors occasionally to review new set-ups in other collegeg, that also would net profitable returns to the curriculum.

Another impetus could be furnished curriculum research in the College by providing competent stenographic assistance. Scholarship and N.Y.A. students, while very helpful for many kinds of employment, are, nevertheless untrained in the performance of those tasks which are most useful in curriculum writing. The re-writing of lecture notes, the preparation of study sheots and course outlines, certain types of library reference and the preparation of tests necessitate trained personnel.

C. The Areas of Individualization of the Student

One of the great needs in the college today is the introduction of the case study method wi th sufficient trained personnel and clerical assistance to maintain it. In Chapter 2 were described the measures which the College now employs in guldance. But all of these measures could be better administered if more of the student story were known.

In the present General Curriculum it is not confidently known that the student grows in either intellectual or social maturity during the extended period in Junior College. The assumption is that he does, but what his actual growth is is not known. A case study of the student, recording his 
activities during these semesters in the General Curriculum might be indicative of the value of the added term. There is no doubt but that it would be helpful to the Comitter who must act semi-annualiy upon the disposition of these students. The values of the General Curriculum need further interpretation.

The case study method was used in a limited fashion in connection with the study of the "experimental" freshman group. The results obtained were so genuinely helpful to understanding the adjustments of this group as to make those who read them realize that no sound educational guidance program can ever expect to proceed without these accompanying student documents.

The case study, further, might furnish the basis for an investigation of the educational needs of students that the various curricula do not now supply. Such a study would be expected to reveal wherein the College falls to reach the student and what adjustment might be made in these hitherto neglected areas. In this sense is meant, for the most part, the social life of the otudents, campus life, student relationships, student problems of employment, health and home adjustments.

It has been shown that vocational offerings have increased greatly during the reorganizational period. The question of the extent of the responsibility of the College to the individual after graduation is raised. In connection 
with its vocational offerings it is advisable that the College take certain steps: (1) the correlation of vocational offerings with the employment situation; (2) the operation of an adequate employment bureau; and (3) a check upon the preparation in these vocational lines through consultations with employers. In connection with the second suggestion above there should be special attention given to the public civic offices for which the College might contribute trained personnel. This seems especially important from the student's viewpoint in view of the fact that the merit system may soon be introduced into City appointments, at least in several departments.

\section{The Area of the Senior College}

A program of testing as extensive as that described in the chapter on the evaluation of achievement is naturally expensive. The most expensive testing in the College is that concerned with the making of Senior College admissions. The costs of the tests are nominal; it is the later work of grading and computation that is expensive. The College has been fortunate in having N.Y.A. assistance during two of the years of testing. In another year it may not be so fortunate. It might be that the costs could be reduced by the elimination of tests. It has been demonstated 
elsewhere in this paper that a high positive order of correlation exists between the national and local tests. A problem for investigation is the determination by actual cases of the outcomes of reducing the test criteria. Another matter pertaining to the expenses of testing that should be followed up concerns the income through special test fees for special testing. In many of the independent high schools and colleges that participate in the Educational Recores Bureau nation-wide testing, students are assessed a fee large enough to cover the expenses indidental to testing. This, also, might be considered further.

In 1933 a few selected freshmen were given the sophomore tests. Eight achieved results well above the norms for sophomores. Herein lies the suggestion that in the future more should be done towards encouraging freshmen to take the sophomore comprehensives and later towards helping them make the academic adjustments suitable to preparation.

The difficulty of evaluating the quality of written work over the period of reorganization because of lack of records has been mentioned previously. Suggested is the preservation of samplings of the written work of students along with the course outlines. Along this same line is suggested the need for a general examination of the quality of acceptable written work, the variation in standards 
between the Colleges, among departments, and the minimum reyuirements in English expression. Not only should such a survey be conducted, it should be maintained, and the periodic, external consideration of quality of student productions of written work become an accepted procedure in the Senior College.

The question of equitableness in grading written work raises also the whole matter of comparability of grades from course to course both in the Junior and Senior Colleges. In the larger sections, where grading may be done on the curve, there is a little variation from accepted standards. But an investigation of teachers' grades would be welcomed by many teachers who often question their own grading. There is one method of comparison of grades with other grades as the criterion that has been employed at oberlin ${ }^{l}$ and that could easily be applied here. Its best recommendation is that the results may be expected to answer three important types of questions in reference to the individual grading of any instructor: (1) how achievement in a course parallels expectations of student ability, (2) whether a teacher is grading more or less strictly than his colleagues, and (3) whether there exist in the College any courses that, due to maladjustment in grades, fall into the "too easy" category.

${ }^{1}$ ohio College Association Bulletin, No. 92. 1935. 
E. The Area of Evaluation of Achievement

I think that it has been fully demonstrated that the College has used in a comprehensive manner objective measurements of its progress adequate to the immediate demands of evaluation. But there have also arisen in connection with the use of these instruments and with the problem of evaluation in general a number of problems, still unsolved. Some, such as fairness in grading, duplication among tests, expense, acceleration of the superior student, acquainting the student with his standing, have already been pointed out in the previous paragraphs.

An outstanding improvement in the construction of tests, and one that would add greatly to the value of the test collection on hand could result from a system utilizing competent senior or graduate students for test making. Not only would the faculty be relleved, but the expectation of an examination of external origin might arouse a different student outlook towards the materials covered. Other advantages are the possibility of being able to keep test items filed in a more avallable arrangement and a more painstaking use of the test data on hand.

A third improvement is seen in colperation with other institutions in the exchange of test materials. No elaborate set-up involving many institutions is advocated. There must first be obtained information concerning the location of courses similar in scope to those offered in the College 
for which objective tests are being built before any attempt at contacts between instructors should be urged. Little has been done in the College towards the construction of objective tests that will measure other than factual types of knowledge. For that mattor little has been done anywhere. In the past year the instructors in history of civilization have made a great deal of progress in the presentation of conceptual materials in their tests. What instructors now know of the opinions and attitudes that arise out of his efforts in the classroom will remain but a hazy speculative figure of imagination until steps towards a more concrete evaluation are taken. It is advised that the gradual inclusion of this type of item in the tests may help bring about a new attitude in the study habits of the student. 


\section{APPENDIX A.}

PROPOSALS CONCERNING THE ORGANIZATION OF THE JUNIOR COLLEGE Passed by the Faculty, March 24, 1933

OBJECTIVES:

I. The Junior College shall make every effort to provide curricula suitable for the following groups:

1. Those students who intend to enter the Senicr College (Pre-Acad.)

2. Those students who intend to enter the professional schools of the University (Pre-Professional).

3. Those students who because of ability, interest or other reasons desire a general cultural education. (Social Intelligence)

4. Those adults who because of a lack of opportunity in early years or a feoling of actual need desire further cultural or vocational education. (Adult Education)

II. One of the prime objectives of the Junior College shall be to provide educational and vocational guidance for each student.

PLACEMENT IN JUNIOR COLLEGE:

Placement in the Junior College shall be partly dependent upon high school education in terms of achievement by means of comprehensive examinations to be given by the College.

Note: Close articulation between local high schools and the College is desirable.

\section{CURRICULUM :}

I. Provision may be made to give opportunity for independent study to those students in the upper quartile who show ability to work independently.

II. All survey courses in the Junior College shall have as prime objective the rounding out of general education in terms of soctal intelligence and not merely the acquiring of enough proficiency to carry on in the next courses of the division.

III. Completion of the requirements of the Junior College shall include satisfactory completion of one semester's attendance in Freshman Survey and a one Year's course in Physical Education.

\section{STANDING:}

I. Any student admitted into the Junior College may be excused from class enrollment in any course when he has satisfied the faculty as to his proficiency therein. In such case the student shall receive the same credit as if he had pursued the work in cursu. In no case shall an accumulation of credits so procured excuse the student from the comprehensive examinations required for completion of the Junior College. 
II. A student may be transferred by the dean from one curriculum to another.

III. A student may remain in the Social Intelifgence Curriculum as long as the faculty feels that he is deriving some benefit from it, and as long as he is not a detriment to the College.

The dean with the approval of the Executive Committee may drop a student because of lack of interest or effort.

IV. Students who are enrolled in pre-academic and pre-professional curricula shall be under the present regulations governing warning, probation, and dismissal. May be transferred to the social

intelligence or Adult Education Curriculum.

V. The faculty upon the recommendation of a division shall designate in which curriculum a course may be placed.

Certain required courses may be open to students enrolled in any curriculum.

The standards of achievement in these courses for credit in the pre-academic and social intelligence curricula shall be determined by the division.

VI. Students in the Social Intelligence Curriculum may be permitted to elect courses in the other curricula. This permission shall be granted by the instructor of the course with the approval of the dean.

VII. A student who is deficient in oral or written English may bo required to do remedial work in the department of English until the deficiency is made up.

COMPLETION OF THE JUNIOR COLLEGE:

I. At the end of approximately two years of study, a student who has sixty hours of credit, exclusive of Physical Education and Freshman Survey, may make application for examination in the following: English Composition, Social Sciences, Humanities, Natural Sciences, Civilizations (to include American Civilization).

The examination in the aforementioned fields shall consist of a battery of comprehensive examinations, and, if the faculty thinks it desirable, partly of oral quizing.

II. The College of Liberal Arts shall recomend that the Junior College may grant a degree of Associate in Arts to those students who have fulfilled the following requirements:

1. Passing grades in sixty (60) hours of work, exclusive of Physical Education and Freshman Survey, done in the Junior College.

2. Satisfactory achievement in the comprehensive examinations.

The examinations and standards of achievement shall be approved by a committe $\theta$ of the faculty known as the committer on Examinations appointed by the dean of the College. 


\section{PROPOSALS FOR THE SENIOR COLLEGE (REVISED)}

Passed by the Faculty, March 28, 1933

The Senior College comrittee submits the following recomendations for the reorganization of the Senior College:

I. Aim and Method: The Senicr College shall be primarily concerne dwith the specialized, liberal, and vocational education of the student. The method of instruction shall be in large measure comparable to that at the Graduate level, viz., tutorial, seminars, theses, independent study, reading periods, etc.

II. Degrees: A student may pursue a two-year curriculum leading to the degres of Bachelor of Arts; or (with the concurrence of the Graduate School) a three-year program in certain divisions leading to the degree of Master of Arts.

III. Admission: Admission to the Senior College shall be granted if the student meots the following requirements:

A. Regular 1. Satisfactory completion of sixty-one (61) hours of Junior College work with a general grade point average of 1.00 (C).

2. A sophomore comprehensive examination including an examination on a year course of sophomore grade in a specific field. The degree of proficlency to be attained in this examination shall be determined by the Senicr College divisions and departments concerned.

3. Recommendation of the division which the student wishes to enter.

B. Conditional

1. A student may be admitted on condition by a divisional committee with the approval of the dean.

2. A transfer student who fulfills requirement one (1) as stated above may be admitted provisionally with the approval of the dean. In such a case requirement two (2) as stated above must be fulfilled before the end of the first year of residence.

IV. Divisions: The Senior College shall be made up of the following divisions: Social Sciences, Humanities and Natural Sciences. Special vocational and pre-professional curricula may be established. 
V. Program: Of the two-year program eighteen to twenty-four (18-24) hours shall be in the special field of study, eighteen to twenty-four $(18-24)$ hours within the division chosen and the remaining shall be outside the division chosen. The student may take a cobrdinating course in the department or fleld of special study. He may also take one or more year courses on the independent study plan.

A divisional committee, with the approval of the dean (and in the case of a three-year program) with the approval of the director of the Graduate School, may outino an individual curriculum to met the particular needs of a student.

Not more than one-sixth of the student's work may be elected in the Junior College.

Each division may set up general and special prerequisites and requirements for its curriculum.

VI. Standing: At any time a student who does not maintain a "C" average may be put on probation, dropped, or transferred to the Junior Coliege. The Division Committee Chairman and the dean will determine what to do with them.

A student whose work in any course is deficient in oral or written English may be required to do remedial work in the department of English until the deficiency is made up.

VII. Graduation: The requirements for graduation from the Senior College shall be as follows:

1. A total of at least sixty (60) semester hours with no grade less than "C" counting towards a degre日.

2. Passing a divisicnal comprehensive examination.

3. Passing a departmental comprehensive examination, part of which may be oral.

Students who produce an unusual quality of work and wo have done at least one year ( 6 hours) of work in independent study may be recommended for honors in a particular field or division by the faculty of the divisions.

Candidates for combined degrees shall comply with requirements one and two ( 1 and 2 ) as stated above. In lieu of the departmentall comprehen sive examination he shall take an examination prepared by members of the faculties of the College of Liberal Arts and of the professional school concerned. This departmental examination shall include the implications of the three years' liberal arts training to the profession. 
APPENDIX $C$

Part I

(b) List of Evidences of Institution's Study of Its Own Problems.

I. Placement Tests and Grades:

A. Placement Test Program for All Entering Students.

Since 1930 we have given regularly the American Council

Psychological Examination and oither the Columbia Research Bureau English Test or the Cooperative English Test. For the three past years, we have given, besides the above, tests in American History, Reading, Social Science, Contemporary Affairs, Biology, Chemistry, and a Forelgn

Language. The tests most recently administered:

1. American Council Psychological Examination, 1935 Use of Results:

a. advising on student load

b. sectioning in English and Chemistry

c. equating sections in experimental studies of teaching methods

d. advising students who fail

e. identifying the superior

f. In connection with other data, to determine Senior College admittance

g. granting of scholarships

z. Cobperative English Test, 1932

Use of results:

a. sectioning in English

b. forming special remedial groups

c. exempting from first semester English

d. pre-test; used again at the end of semester to measure progress; also, at end of sophomore year

3. Nelson Denny Reading Test, Form A

Use of results :

a. a diagnostic instrument

4. Cobperative Foreign Language Test

Use of results :

a. sectioning in language; high school credit is disregarded entirely in our sectioning

b. exemptions from further study of a language in $\operatorname{college}$

5. Kentucky Classification Test, Form A Use of results:

a. a check on the American Council Test

b. for comparison of the group with other high school groups in Kentucky 
6. American History, 1934

Use of results:

a. to advise students of their need to take

American History in college

B. Correlations:

1. Success in Particular Subjects and American Council Psychological Examination Score

2. Success in Particular Subjects and Kentucky Classification Test Score

3. Average Grade Standing and American Council Psychological Examination Score

4. Average Grade Standing and Kentucky Classification Test Score

5. Average Grade Standing and Otis Intelligence Test Score

6. Score on American Council Psychological Examination and Score on Kentucky Classification Test

7. Grades in Social Science and Score on Social Science Test (a college test)

8. American Council Psychological Examination Score and Cobperative English Test, Series 1, 1932

9. Harry Sones High School Achievement Test Score and Average Grade Standing in Freshman Year

10. Score on Social Science Section of Harry Sones High School Achievement Test and Score on Social Sclence Test (a college test)

11. American Council Psychological Examination and Average Point Standing for Freshmen, First Semester, 1932-1933

12. Sones Harry High School Achievement Test and Average Point Standing for Freshmen, First Semester, 1932-1933

13. Kentucky Classification Test and Average Point Standing First Semester, 1932-1933

14. American Council Psychological Examination and Colperative English Test, a Placement Tests, September, 1933

15. Scores on Social Science Section of Sones Harry High School Achlevement Test and Scores on the College Social Science Test Used for Freshman Placement Test, September, 1932

16. Scores on Sones Harry Social Science Section, May, 1932, and Average Point Standing in Social Science for the Year, 1932-1933

17. Score on College Social Science Test Given to Entering Freshmen, September, 1932, and Grades in Social Science, First Semester

18. Score on College Social Science Test Given to Entering Freshmen, September, 1932, and an Average Grade in Social Science, Second Semester

19. Score on College Social Science Test Given to Entering Freshmen, September, 1932, and an Average Grade in Social Science for the Two Semesters 
C. Other Studies or Criteria Established:

1. Admittance of an "Experimental" Group of Freshmen. These freshmen had not graduated from high school. Their success is being carefully watched.

2. Standard tests are used as course examinations whenever they are available in the subjects. They are used regularly in Biology, Chemistry, Physics, English Composition, all foreign languages, Algebra, and Trigonometry and Astronomy.

3. Abolished credit requirement in language. On the bases of scores obtained from our final examinations. A period of three years and the national norms for the tests, minimum achievement scores in reading, grammar, and vocabulary are required in fulfillment of the foreign language requirement.

4. Registrar annually reports grade curves for al 1 courses, and for departments.

5. A minimum achievement on comprehensives (standardized and non-standardized, college constructed) is required before entrance upon senior College work, of majors in the senior year, and for graduation from the $\operatorname{colleg\theta }$, this in addition to the usual requirements of credits and grade point standing.

6. Classification by aptitude test scores of students who withdraw from the College.

7. A follow-up study of students dismissed from the College for poor scholarship but re-admitted after one semester.

8. Student mortality over a period of seven years.

III. Bibliographies in Research:

1. Diagnostic and Remedial Teaching

2. Tutoring

3. Remedial Reading

4. Problems in College Teaching

5. Science in Education

6. Thesis Writing and Research

7. Interviewing

8. Improvement of Objective Tests

9. Employment Tests

10. The Questionnaire 
11. The Reliability of Tests

12. Reading

13. Test Validity

14. Folk Schools

15. Two Factor Theory

16. College Teaching

III. Construction of Comprehensive Examinations:

A. Tests:

1. General Biology

z. History of Civilization (One each year)

3. American His tory

4. Social Science Survey (One each year)

5. Natural Science Survey (One each year)

6. Inorgan ic Chemistry

7. Humanities Survey (One each year)

8. Methods of Teaching

9. Annual comprehensives in all of the major subjects

10. Educational Psychology

B. Studies in the Technique of Test Construction

1. Preparation of a Library of Test Items in the Social Sciences, Humanities, Natural Sciences, Freshman English, History of Civilization

2. Comparison of the Validities of Different Types of Test Items - Matching, Multiple Cholce, and True-False

3. Correlation between Nationally and Locally Constructed Tests in Natural Sciences, Social

Sciences and Humanities

4. Steps in the Standardization of an American History Test for Possible Use in Kentucky High Schools

5. Comparison of Validity Index of Test Items and Difficulty of Test Items

6. Comparative Validities of the Same Objective Test at Different Testings

7. Changes in Difficulty of the Items of the Same Objective Test at Different Testings at Different Academic Levels

8. The Effect of Changed Testing Conditions upon the Validities of Test Items 
9. Comparison of the Average Validity of the Test with the Reliability Coefficient

IV. College Sophomore Test, (Colperative Test Service)

A. Objectives:

1. To determine the level of sophomore achievement in comparison with other colleges

2. To give each department an idea of the extent of preparation in various subjects of its prospective majors

3. To begin to work towards setting a standard of minimum achievement for Senior College standing

4. To give each department a basis for evaluating the effectiveness of its courses

5. To give the student the benefit of objective evidence of his comparative abhievements in the fields studied

Results and the various studies made were presented in faculty meetings. Slides were made for our stereoptican and the graphic representations of the results flashed on a screen in faculty meotings.

B. Correlation Studies:

1. Otis Intelligence Test and American Council Psychological Examination

2. Point standing in Science and General Scores in Science (All cases regardless of previous training)

3. Point Standing in Science and General Score in Science (Over 10 hours of College Science)

4. Point Standing in Science and General Score in Science (Ten hours or less of College Science)

5. Point Standing and Total Score (Women)

6. Point Standing and Total Score (Men)

7. Hours of Science in College and General Science Score

8. Total Hours of Science in High School and College and General Science Score

9. American Council Psychological Test Score and General Science Score

10. Otis Intelligence Test Score and General Science Score

11. American Council Psychological Test Score and Point Standing in Science

12. Otis Intelligence Test and Point Standing in Science

13. History Score and Hours of History

14. Fine Arts Score and Combined Literature Score

15. General Score and Point Standing

16. General Science Score and American Council Psychological Examination 
17. Afroement and Overlapping on the College-Constructed Sophomore Comprehensives and the Nationally Constructed Sophomore Comprehensives Used in May, 1935

C. Comparison in Detail of Scores on the Various Tests Included in the Sophomore Examination with College Grades in the subject, covering the following:

1. Gross Achievement Score and Average Point Standing

2. English Usage and English Grades

3. Foreign Iiterature Score and General Literature Grades

4. Total English and Foreign Literature Scores and Grades in Freshman-Sophomore English

5. English Literature Score and Grades in General and English Literature

6. History Score and History Grades

7. General Science Score and Biology Grades

8. General Science Score and Chemistry Grades

9. General Culture Score and American Council Psychological Examination

D. Study of Scores on the Various Tests in Relation to the Chosen Major of These Sophomore Students, including the following majors:

1. Chemistry

¿. Mathematics

3.Pre-Dental

4. Pre-Law

5. Pre-Medical

6. Economics

7. Home Economics

8. Biology

9. Romance Languages

10. English

11. History

V. College Achievement Test: (Senior Examination)

A. Objectives:

1. To determine the level of college achievement in comparison with other colleges

2. To give the individual department an idea of the extent of achievement of its majors in various

fields that they may have some basis for evaluating their methods and curricula

3. To have some more reliable record of the student's achievement in college than that furnished by his college grades 
4. To have a comprehensive summary of the individual student's attainment in comparison with that of his fellows, and thus have an objective statement of the combined ability and persistence of the student

B. Study by Majors of Achievement on the Test, including the following majors:

1. Sociology

2. Philosophy and Psychology

3. Education

4. Economics

5. Biology

6. Mathematics

7. Chemistry

8. History

C. Fluctuations and Trends in Achlevement in Scholarship in the College for Three Years as Evidenced by the Pennsylvania College Achievement Test

D. Study of the Education Major:

1. Performance on College Achievement Test

2. Performance on Cobperative Professional Education Test

3. Distribution of Hours Among Departments

4. Levels at Which Work Was Distributed

E. Study of Testing in the College for the Past Four Years. Included:

1. Varlations by classes in achievement; general trends and changes in the nature of achievement in particular subjects and divisions

2. Study of the Major: Various losses and improvements since changed curriculum and major requirements have been set up

VI. Guidance:

1. Comprehensive Testing at End of Sophomore Year (To determine fitness for entrance upon Senior College work and to determine best policies for individual students)

2. The Establishment of Criteria of College Achievement in the Foreign Languages. This measure has been one of our earliest attempts to eliminate the lock-stepcredit system and to provide for individual rates of progress 
3. Use of the American Council College Personnel Card. All test data and grades are plotted. As complete record is kept as possible, in order that the adviser mayhave the best possible picture of the student. This system has been operating since September, 1932 .

4. The Registrar maintains a placement bureau for graduates and alumnae

5. Annual symposiums on Vocations are conducted. All students may attend. This year a program is being conducted over the radio

6. Improvement of Reading Deficiency of Low Group of Freshmen

7. Tutoring of Failing Students byProspective (student) Teachers

8. System of Faculty Advisers. The student reports formally to his adviser six times during the year, twice to register, four times for grades.

\section{Improvement of Instruction}

1. Advisability of Hurdle Method for Releasing Brighter Students Prematurely from the Full Semester of Required English

2. Effect of the Hurdle Method on the Improvement of Deficiency in English Usage

3. Student Opinion in the Building of the Curriculum. We have at various times called upon the student body for information relative to the materials and methods of instruction. It is the practice to solicit student criticism in the survey courses. At the present time a student committee is proposing curricula for the Freshman Survey course; student committer directed our student rating of teachers.

4. Difficulty of Courses Singly and by Departments and Teachers. Criterion: the student's grades in all other courses than the one being studied.

5. Repetition of the English Placement Test at the End of the First Semester of English Composition. Our English group is extremely low at entrance. We have experimented for two years with various arrangements of classes so that this deficiency may be rectified. The test is the gauge of success. 
6. Faculty Symposium on the Improvement of Instruction. A faculty committee issued a questionnaire entitled, "The Advantages and Disadvantages of Various Teaching Methods." The summary of answers obtained was sent to each faculty member. A helpful bibliography was also issued.

7. Student Rating of Teachers. From 4,000 ratings for a faculty of 32 , interesting studies have been made. Purpose, to stimulate teacher self-criticism and interchange of faculty comment upon the characteristics of the successful teacher; to give the teacher an indication of his students' opinions concerning special traits that enter into teaching.

8. Printed Course Outlines. Printed course outlines are prepared in all of the Junior College survey courses and in most of the other courses. In every course, it is required that bibliographic and additional references be supplied the student. Some courser provide additional terminology and problem sheets. This type of curriculum ald is especially essential in our institution due to our allowances of credit for independent study, and extra-mural work in the cases of superior students.

9. Value of a Quiz Section in the Teaching of History of Civilization

IX. Miscellaneous :

1. Effect of Poor Vision on Ability in English Mechanics

2. Student Retention: A Follow-Up Study of Student Mortality in the College Over a Period of Several Years

3. Differences in Performance on Standardized Biology Test of Pre-Medical and Regular Liberal Arts Students in the General Biology Course

4. Effect of Previous Training in Chemistry on Achievement in General Chemistry

5. Teacher Rating Study

6. Achievement in the Freshman Year as Measured by the Available Standardized Tests

7. Reading as a Factor in Successful Work in Social Science 
8. The Inclusion of Achlevement on Intelligence, English, and Accuracy Tests as one of the Bases for Selecting University Employees

9. Analysis of Results Obtained from Administration of the Manly Harper Test, A Social Study, to Members of a Class in Philosophy of Education

10. Cobperation in Kentucky State Testing Program

11. Factors Most Contributive to Success in Social Science as Measured by the Social Science Test: Reading Test, Contemporary Affairs Test Score, Total Fsychological Examination Score, and Individual Parts of Psychological Examination 


\section{STUDENT STATEMENT OF INTERESTS IN INDEPENDENT STUDY}

"Am pre-1aw student. . main interest corporation law with emphasis on railroads. Consequently, interested in financial problems of railroads."

"When the opportunity of studying in the FERA Nursery School presented itself $I$ was desirous of taking advantage of it. . . as I intend to make nursery school teaching my profession."

"In reading certain plays I noticed a definite adherence to Freudian principles. I became interested in determining the importance and extent of this influence in the works of the newer dramatists."

"From a study of Emily Dickenson which I recently made, I have become interested in obscure women writers of that period in the late nineteenth century who had they had in Virginia Wolf's phraseology "a room of their own, and five hundred pounds a year might have become poets and writers of note themselves."

"Retail store merchandising. - have had some experience in this field and hope to make it my life work."

"From the condensed version of a manuscript I wrote for Advanced Composition I have attempted to write a full length novel. Problems of character development are my chief writing interest."

"My father is a retail coal dealer, and I feel that the study of the distribution phase will be a valuable asset to me since I expect to enter the business with him."

"My interest in lumber is due to the fact that I am employed by a Iumber company (Mengel Body Company) and naturaliy would like to know as much as I can about that product. The particular interest I have is in the statistics of lumber production in the various kinds of woods used by the concern for which I work."

"I am very much interested in every branch of journalism and wish particularly to gain additional practice in writing feature articles. I should also Ilke to learn more about the various types of articles and the scope of feature writing."

"I like to write but, being a mathematics major and saturated with science courses, I know fow of even the fundamentals of writing. These I hope to gain through study and use."

\#Interestlargely vocational. May become affiliated with local concern in sales capacity and desired some foundation work in the field."

"In Indiana the School laws require that each teacher holding a special license in a particular subject have had a course in the teaching of that particular subject. Mathematics is the one in which I have chosen to qualify for this special license."

"Desire to do research work in qualitative chemistry due to present analytical work for city." 
"This particular problem has been chosen in anticipation of a study to be made by me in the fall, under experimental conditions, of the effect of various emotional disturbances upon the learning of sixth, seventh and eighth grade children. It has been undertaken th the expectation of securing a background, as rich as possible through a survey and critical evaluation of the literature in this field."

"I knew something of the techniques of detemining reliability of tests but nothing of the factors and assumptions involved. This is a seemingly narrow problem but actually is very broad; it was my desire to learn whetever I was prepared to assimilate of it that I might relate my findings in my job."

\section{APPENDIX E \\ TOPICS IN INDEPENDENT STUDY, 1934-35}

Celtic Culture in the Early Middle Ages

Railroad Finance

Feeding Problems in the Nursery Schools

The Influence of Women on Certain of the Lake Poets

The Influence of the Freudian Doctrine on Modern Drama

The Psychology of Feeding in Child Care

Principles of Foreign Trade, Especially Between South America and the United States

Determining the Reliability of objective Tests

A Testing Program for the Federal School in Virginia

Measurement of Mental Ability: Spearman's Two Factor Theory, Thurstone's Multiple Factor Theory and Their Applications to Education and Personality

The Effect of Emotional Disturbance on Learning

Children's Activities as Materials for Education

Evaluation of Recent Books on Social Sciences in Reference to Civic Education in Louisville

The Use of Tests in Senior High School

Certain Factors Affecting the speed of Reading

Insecticidal Compounds from the Industrial Standpoint

American Foreign Policy

Economic and Social Survey of Soviet Rusia

Investment Problems and Industrial Securities

From Mechanical Analysis Toward Organic Integration in Natural sciences

Retail Merchandising

The Teaching of Secondary Mathematics

Salesmanship and Industrial Marketing

Advanced Composition in the Field of Subjective Narration and Description

Feature Writing

Economics of Industry

Coal Industry

Advertising in Business

Unemployment Insurance

Dramatic Works of Hauptmann

Modern German Lyricists with Emphasis on Rilke

Creative Writing in Short Story and Full Length Novel

The World Press

A Study of a Portion of George Santayana's Philosophy

Medieval History: General Survey of the High Middle Ages and Its

Cultural Aspects

Retail Store Merchandising in Department Stores 
APPENDIX F

ORGANIZATION OF FACULTY COMAITEE TO FORULATE A GENERAL PROGRAM FOR THE COLLESE

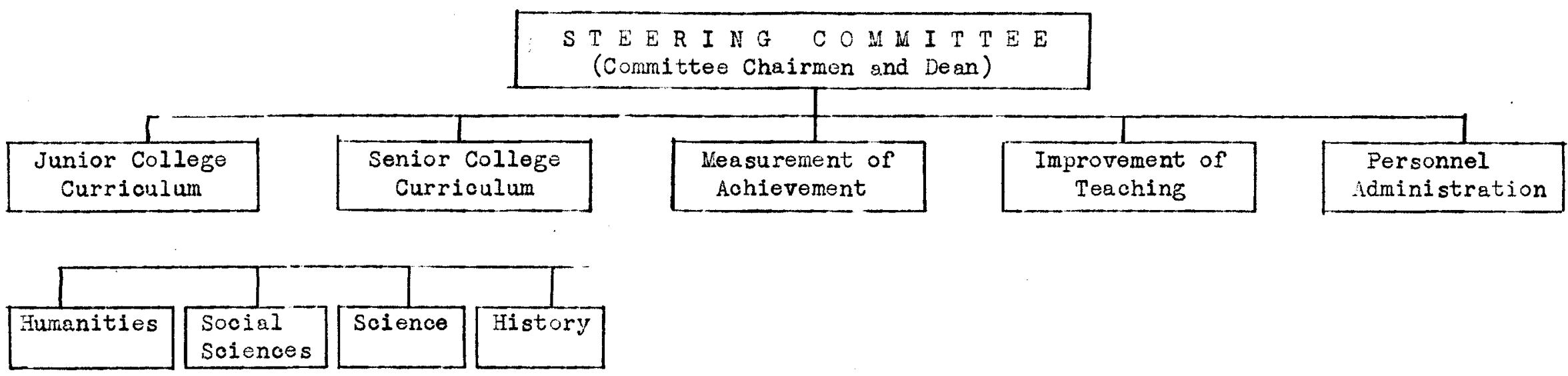

Objectives of
the Junior Col-
lege.
Articulation with
High School.
Survey Courses.
Skill Courses
Differentiated
Curricula.

Jonors and Inde-
pendent Study.
Nature of Senior
College Courses.
Integration of
fields. with
Graduate School.
Service Subjeots.
articuiation with
Junior College.

Placement rogram
Entrance Examina-
tion.
Objectives of
Testing
Comprehensive Exa
minations:
Honors
Departments
Generul

Methods of meach-
ing in Junior
College.
Tuturiol Hids.
Reports, Papers
Wethods of Teach-
Ing in Senior
College.
Large Cless
Methods.

Freshman Advisins.

Advising Najors.

Placement Service.

Vocational Guidance.

Physical and Mental Health.

Community Service. Sooial Education. Public Contacts. 
APPENDIX G

PROPOSALS CONCERNING THE GENERAL ORGANIZATION OF THE COLLEGE

I. That the College make a more definite division between the junior and senior divisions.

II. That the junior college shall promote, with ever increasing emphasis, the following as its chief objectives:

1. Rounding out of the general education begun in high school

2. Preparation of students for effective work in the senior college

3. Preparation of students for the professional schools

4. Offering broad cultural training for trose adults who desire it

III. That increasingly the College shall endeavor to determine advancement in learning on the basis of achievement rather than on the timecredit basis.

IV. That the greater emphasis shall be on learning by the student with less emphasis on teaching. This means increasing the student's responsibility for his own education.

V. That it be realized that the prime function of the teacher is to stimulate and guide.

VI. That the real worth of the following changes be set forth in such a manner that the College will look upon them with favor:

1. Use of the comprehensive examination both oral and written

2. Application of individual study plans

3. Integration of fields of learning

4. Establishment of inter-departmental seminars

VII. That divisional organization supersede departmental organization. 